\title{
Volume 5, Number 3
}

\section{Hipatia Press}

www.hipatiapress.com

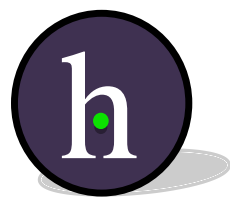

The Tricky "True Object": Bourdieu's Masculine Domination and Historicity" - Miklós Hadas.

Mobile Masculinities: An Investigation of Networked Masculinities in Gay Dating Apps - Nathian Shae Rodriguez, Jennifer Huemmer \& Lindsey E. Blumell

Articles The Five Stages of Masculinity: A New Model for Understanding Masculinities- Joseph Gelfer

Licencias de Paternidad y Permisos Parentales en América Latina y el Caribe. Herramientas Indispensables para Propiciar la Mayor Participación de los Padres en el Cuidado de los Hijos e Hijas- Carina Lupica.

Men, Masculinities and Teaching in Early Childhood Education- Javier Díez-Palomar

\section{Reviews}

Masculinity and the New Imperialism: Rewriting Manhood in British Popular Literature, 1870-1914 - Teresa Morlà Folch 323 


\section{Hipatia Press}

Instructions for authors, subscriptions and further details:

\section{http://mcs.hipatiapress.com}

\section{The Tricky "True Object": Bourdieu's Masculine Domination and Historicity"}

Miklós Hadas ${ }^{1}$

1) Corvinus University of Budapest - Institute of Sociology, Hungary

Date of publication: October 21st, 2016

Edition period: October 2016 - February 2017

To cite this article: Hadas, M. (2016). The Tricky "True Object": Bourdieu's Masculine Domination and Historicity Masculinities and Social Change,5(3),210-240. doi: 10.17583/MCS.2016.2029

To link this article: http://doi.org/10.17583/MCS.2016.2029

PLEASE SCROLL DOWN FOR ARTICLE

The terms and conditions of use are related to the Open Journal System and to Creative Commons Attribution License (CC-BY). 
MCS - Masculinities and Social Change Vol. 5 No. 3 October 2016

pp. $210-240$

\title{
The Tricky "True Object": Bourdieu's Masculine Domination and Historicity
}

\author{
Miklós Hadas \\ Corvinus University of Budapest, Hungary
}

\begin{abstract}
Pierre Bourdieu's Domination masculine (1998) has an earlier version published as an article in 1990. In order to deconstruct in vivo the working of sociological paradigm-alchemy, a close reading of the Bourdieusian narratives is offered. The paper starts with a comparison of the article and the book. After summing up the main claims of the book's critical reception, Bourdieu's statements are intended to be questioned, according to which the school, the family, the state and the church would reproduce, in the long run, masculine domination. The paper also seeks to identify the methodological trick of the Bourdieusian vision on history, namely that, metaphorically speaking, he compares the streaming river to the riverside cliffs. It is argued that when Bourdieu discusses "the constancy of habitus", the "permanence in and through change", or the "strength of the structure", he extends his paradigm about the displacement of the social structure to the displacement of the men/women relationship. Hence, it is suggested that, in opposition to Bourdieu's thesis, masculine domination is not of universal validity but its structural weight and character have fundamentally changed in the long run.
\end{abstract}

Keywords: domination masculine, Bourdieu, historicity

2016 Hipatia Press

ISSN: 2014-3605

DOI: 10.17583/MCS.2016.2029

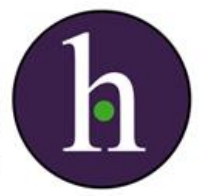




\title{
El Complicado "Objeto Real": La
}

\section{Dominación Masculina de Bourdieu y}

\section{y la Historicidad}

\author{
Miklós Hadas \\ Corvinus University of Budapest, Hungary
}

\section{Resumen}

La dominación masculina de Pierre Bourdieu (1998) tiene una versión anterior publicada como artículo en 1990. Con el fin de deconstruir el funcionamiento del paradigma sociológico-alquimia, se ofrece una lectura atenta de las narrativas alrededor de este autor. El artículo comienza con una comparación del artículo y el libro mencionados. Después de resumir las principales contribuciones alrededor de la recepción crítica del libro, los argumentos de Bourdieu son cuestionados, en particular sobre su posicionamiento alrededor de la escuela, la familia, el estado y la iglesia, las cuales se encargan de reproducir, a largo plazo, la dominación masculina. El artículo también trata de identificar el truco metodológico de la visión bourdieusiana en la historia, a saber, que, metafóricamente hablando, se compara el río a los acantilados de la orilla. Se argumenta que cuando Bourdieu habla de "la constancia de habitus", la "permanencia y mediante el cambio", o la "resistencia de la estructura", se extiende en su postura sobre el desplazamiento de la estructura social y el desplazamiento de la relación hombres - mujeres. Por lo tanto, se sugiere que, en oposición a la tesis de Bourdieu, la dominación masculina no es de validez universal ya que su peso estructural y carácter han cambiado de manera fundamental en los últimos años.

Palabras clave: dominación masculina, Bourdieu, historicidad 



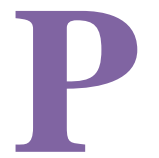

ierre Bourdieu's Masculine Domination (Bourdieu, 1998) was granted the privilege of becoming a sociological classic in his lifetime. Published in French in 1988 and then within a few years in several languages, this publication is noteworthy for several reasons. First, since publication in 1998 it has had unparalleled appeal in France, being published in 78000 copies in 1998 and another 30 000 copies four years later. These are stellar numbers for a social science publication. Of his works, only La misere du monde (1993) and the items of the Liber Raison d'agir-series were printed in more copies (Thébaud, 2006, pp. 175-176). Second, it is important because - though gender inequalities were latently included in earlier phases of the oeuvre - it became the target of concentrated attention towards the end of the author's career and can, therefore, help the reinterpretation of the life's work retrospectively. Thirdly, the book is intriguing because like a teaching aid it demonstrates several virtues and limitations of Bourdieu's thinking in a concentrated form. Below, after starting with a short comparison of the Masculine Domination's two versions, the main statements of the book's critical reception will be summed up. Then, on the basis of questioning Bourdieu's claims, namely that the school, the family, the state and the church would reproduce, in the long run, masculine domination, the paper will seek to identify the main problem of the Bourdieusian vision on history.

\section{The Article and the Book}

When the readers take the English version of Pierre Bourdieu's Masculine Domination (2001) in hand, they are probably unaware that this book has an earlier version (Bourdieu, 1990) published as an article in Actes de la recherche en sciences sociales, the journal he founded in 1975 and headed until his death. We thus have the exceptional chance to steal a glimpse of the creative Bourdieusian workshop and study in vivo the working of the sociological paradigm-alchemy by starting with a short comparison of the article of 1990 and the book of 1998.

The main thesis of the article is that masculine domination - actually the model of all kinds of domination - is a social institution deeply inculcated in the objective social and subjective mental structures over the millennia, practically structured by the same laws in the pre-modern Kabyle society of 
the Mediterranean region as in London's Bloomsbury district in the early $20^{\text {th }}$ century, in Virginia Woolf's circle. The basis for its emergence is the libido dominandi or the instinctive desire after domination, a sort of sense of duty based on an inner drive that a man "owes himself", acquired unconsciously in the course of socialisation. This drive, or illusio dominandi, is constitutive of masculinity, and causes men to be socially instituted to let themselves be caught up, like children, in all the games of domination that are socially assigned to them, of which the form par excellence is war. At the same time, men also become victims - victims of their own illusion.

In this sexually determined, "sexualized and sexualizing" social order of labour division, men are active mainly in the public spheres, while women in the non-public, private spheres are not oriented towards profit or power and mostly require unlimited time input. The latter are practically goods of exchange in the games of men based on honour and dignity, serving in this capacity the reproduction of men's symbolic capital. Women, argues the author, are disposed to generate liking, hence it is no wonder that they spend a considerable part of their time with cosmetic work. They are mainly in charge of the ceremonies organised upon aesthetic rules (family and firm feasts, literary salons, receptions, etc.), so they may fill important positions in different cultural fields and are specialised for producing, differentiating symbolic distinctions. Besides, continues Bourdieu, borrowing the nice metaphor of Virginia Woolf, they act as flattering mirrors in which men can view their enlarged images. Ultimately, then, all women do enrich the wealth of men who possess them. At the same time, they have the perspicacity of the outsiders, so they can view the "most serious" games of men "with amused indulgence".

It is ascribed salient significance to habitus, i.e. behavioural patterns fixed in durable dispositions, which govern human praxis at the nonconscious level; being perceptible, these "structured, structural structures" are liable to social classification and differentiation. Bourdieu writes about "the somatisation of power relations", and formulates the thesis according to which the socially constructed biological body is also a politicised body, or, more precisely, no less than "embodied politics". He refers, among others, to elementary school education which incorporates in the dispositions of growing generations a multitude of sexually differentiated 


\section{Hadas - The Tricky "True Object"}

ethical, political, or even cosmological elements - e.g. teaching pupils how to hold the (masculine) right hand, how to walk, look into someone's eyes, dress - and so on, and so forth...

The arguments are supported on the basis of two empirical references. The main empirical source is the pre-modern Kabylian community in Algeria, where women are mainly associated with negative connotations while men with positive ones (they are like nobles, notes the author). All activities connected with the concepts of "internal", "damp", "low" and "crooked" (not only child-rearing but such dirty chores as mucking out the stable) are performed by women, as compared to the "external", "official", "straight", "dry", "tall" (etc.) activities of men. Interesting paragraphs can be read about the manifestation of the major cultural oppositions in the division of the body: high/low, up/down, pure/ impure, public/ private, legitimate/illegitimate. (Typically enough, the sexual intercourse itself is deemed "normal" and "classical" in the case where man is over woman, while all other positions of love-making are condemned as perverted and often penalised by sanctions.)

The other reference is Virginia Woolf's To the Lighthouse, the protagonist of which, Mr Ramsey is an excellent figure to illustrate moderntime masculine dispositions based on the libido academica, ie. a special variation of the libido dominandi. An early $20^{\text {th }}$-century academic intellectual, Mr Ramsey is a man "of whose words are verdicts", all whose predictions "are self-fulfilling, they make themselves true", and whose "paternal prophecy is both a forecast of science and a prediction of wisdom, which sends the future into the past". He experiences the fantasies of e libido academica which express themselves in warlike games: "Yet he would not die lying down; he would find some crag of rock, and there, his eyes fixed on the storm ... he would die standing" (Woolf is quoted by Bourdieu - Bourdieu's italics).

These statements are formulated almost unchanged in the book of 1998: there is no substantial difference between the two texts as to the set of concepts and the empirical basis. However, there are significant differences between the two versions. First, to start with a seemingly less important element, there are considerable aesthetic differences between the two versions, to the benefit of the latter. Bourdieu was presumably dissatisfied with the formal structure of the article. As a normalien, i.e. one-time student 
of a Grande École of the French social scientific elite of greatest prestige, the École Normale Supérieure founded by Napoleon, he would have been heir to a philosophical tradition which ascribes at least as much significance to the "form" as to the "contents". That means that ideas should be put forth with the elegance of the continuous resolution of (seeming) paradoxes arising from binary oppositions. Needless to say: this obligation is satisfied with self-evident ease in the author's first text variant, too - as in nearly all his works.

While the article was divided into seven chapters of varying length and more or less ad hoc titles (Symbolic rape: physical compulsion; Somatisation of power relations; Social construction of sexuality; Social genesis of illusion and libido dominandi; Clearsightedness of the outsiders; Women as objects of exchange; The institutional libido), the book appears to comply more thoroughly with the formal requirements of the scholastic tradition. It is divided into three parts, the first (A magnified image) containing five, the last (Permanence and change) four (?) $)^{1}$, the middle chapter (Anamneses of the hidden constants) three sections, and the whole being framed by a preamble and a conclusion. Thus, a quasi-symmetry is created, which is at the same time put in parentheses via a subtle structural dissonance, in order to avoid the appearance of orthodox conservatism.

In the English version, the Latin references are lost. The "preamble" is rendered as "prelude", the "post-scriptum" as "postscript", the latter omitted from the contents; hence the discussion about love is "hidden" in the English edition. The post-scriptum may belong to the third part - extending it to five sections - or may not. It also depends on the vantage point whether the appendix is taken for an essential (sub) chapter upsetting the formal balance, or for a structural unit of secondary importance compared to the primary argumentation. At any rate, the fact that the author attaches this section after his final conclusion appears to suggest that his thoughts about the gay and lesbian movement are beyond his main concern.

But however important the requirements of a rhetoric tradition may be, they are certainly insufficient to prompt a new text variant. That needs other things, too. Such as - to mention another important factor that has great significance in the French intellectual context with a penchant for subtle distinctions - the altered reference horizon that is deemed important for the argumentation. Taking a close look at the sources and references in the two 


\section{Hadas - The Tricky "True Object"}

texts, considerable differences can be found. What first strikes the eye is the conspicuously high number of self-citations (eight in the article and fourteen in the book). The index of the French edition does not contain the Bourdieu name, so the self-citations can only be gleaned from the text one by one.

The English version is more correct, including the Bourdieu-item in the index. It is not clear, however, why only eight of his works are named as references. Furthermore, the number of an item's occurrence is also lower than actually is the case. For example, out of the 14 references to The Logic of Practice, a mere four are noted in the English edition. The other four selfreferences of the article (Le nord et le midi; L'ontologie politique de Martin Heidegger, La noblesse d'état and Le patronat) are not included in the book. By contrast, there are six references in the book to pre-1990 writings that are not named in the article. All in all, the number of self-references is seventeen in the article and twenty-seven in the book.

As for references to others, in both versions, there are relatively few citations of other authors. Still, there are far more references in the book, so it is clear - especially in the light of what was said above about the formal structure - that the enlarged version satisfies more completely the requirements of scholasticism. The top list of authors in the book is led by Foucault and Sartre with four mentions, respectively. Foucault's importance had grown with the passing of the time (from one reference in the article). Although in most cases his name appears in a polemic context, the fact that Bourdieu finds him (of all people) worth arguing with is significant. The opposite is the case with Sartre. In the article there is a lengthy, though small-typed, particularly méchant passage about how the philosopher's private imagination-laden with fears of castration, conceiving of the sexual act via the metaphor of "a wasp drowned in jam", becomes a "fundamental philosophical intuition" - a kind of intuition that discusses with self-evident ease the "honey-sweet death of the für-sich" (Bourdieu, 1990, p. 15)2.

In the article, he makes a reference to some thirty authors, usually one (rarely two-three) time(s). They include those often cited in other Bourdieu works (Bergson, Goffmann, Kant, Husserl, Kafka, Lévi-Strauss, Van Gennep, Freud, Lacan) and some less known, mainly French researchers not connected to feminism. In a footnote, he refers to the "feminist discourse stranded frequently in essentialism" (Bourdieu, 1990, p. 4), 
naming Féral, Irigaray and Kristeva. Far more authors are cited in the book, usually also only once. From these references, however, not only Féral, Irigaray and Kristeva, but other key authors of Gender Studies are also missing - although he refers to post-1990 works at least thirty times. Among the feminist authors, MacKinnon's Feminism Unmodified (1987) is quoted three times, Chodorow's The Reproduction of Mothering... (1978) is referred to twice, Lee Bartky's Femininity and Domination... (1990) is mentioned once. Judith Butler is also mentioned, but - not really correctly the citation from her is used in support of Bourdieu's argument:

Judith Butler herself seems to reject the "voluntaristic" view of gender that she seemed to put forward in Gender Trouble, when she writes [in Bodies that Matter]: 'The misapprehension about gender performativity is this: that gender is a choice, or that gender is a role, or that gender is a construction that one puts on, as one puts clothes on in the morning' (Butler 1990, p. 103; quoted in Bourdieu, 2001, p. 103).

Unfortunately, Bourdieu forgets to note here that in this passage Butler words the critique of the extreme interpretations of the Gender Trouble. It is thus far from discarding her previous theory, as Bourdieu claims.

The most important difference between the two texts is that Bourdieu includes a completely new chapter, entitled Permanence and Change, plus an appendix and post-scriptum into the book. The inclusion of these new texts, however, does not alter the main thesis about the universality and pertinence of masculine domination. On the contrary: his main thesis is that

The changes visible in conditions in fact conceal permanent features in the relative positions: the levelling-out of the chances of access and rates of representation should not be allowed to mask the inequalities which persist in the distribution of boys and girls among the various types of schooling and therefore among possible careers (Bourdieu, 2001, p. 90).

He uses the term "permanence in and through change" (Bourdieu, 2001, p. 91), by claiming that: 
Whatever their position in the social space, women have in common the fact that they are separated from men by a negative symbolic coefficient which, like skin colour for blacks, or any other sign of membership of a stigmatized group, negatively affects everything that they are and do, and which is the source of a systematic set of homologous differences (Bourdieu, 2001, p. 93).

Consequently, "the structure of the gaps is maintained" (Bourdieu, 2001, p. 91) because "girls internalize, in the form of schemes of perception and appreciation not readily accessible to consciousness, the principles of the dominant vision" (Bourdieu, 2001, p. 95). Or to put it differently: "the constancy of habitus (...) is one of the most important factors in the relative constancy of the structure of the sexual division of labour" (Bourdieu, 2001, p. 95).

In the post-scriptum, writing about domination and love - he states that in border cases there might be exceptions to the general rule of masculine domination. Such a border case is "the enchanted island of love, a closed and perfectly autarkic world which is the site of a continuous series of miracles, can be snatched from the icy waters of calculation, violence and self-interest" (Bourdieu, 2001, p. 110). In the appendix dealing with the gay and lesbian movement, he raises the following questions: "How can one stand up to a hypocritical universalism without universalising a particularism? (...) How can one prevent the conquests of the movement from ending up as a form of ghettoisation?" (Bourdieu, 2001, p. 123) Undoubtedly, the fact that he formulates the problems connected to the gay and lesbian movement in the form of questions suggests some relaxation of his rigid position represented by the article of 1990 where he writes:

Women's studies, black studies, gay studies (...), by turning a social problem raised by a dominated group into a sociological problem without any special procedure, ignore everything that constitutes the reality of the topic while they exchange the social relation of domination with a substantial entity, with an essence, thought in itself and for itself, with an idea of a complementary entity (as happened in the case of men's studies, too) (Bourdieu, 1990, p. 30). 


\section{Critiques to Masculine Domination}

The fact itself that the most prestigious and most often quoted sociologist of the last decades of the $20^{\text {th }}$ century has written a book on masculine domination draws the attention of the international scientific community to this issue. As it was pointed out, Bourdieu gives an elegant and witty analysis of pre-modern mountain Kabyle society, stressing the social embeddedness of masculine domination and its decisive structural weight. The book convincingly points out to certain permanent elements of masculine domination, proving that the habitus-concept might be relevant if we would like to study symbolic domination and symbolic violence. The value of the book is further enhanced by some conceptual innovations, like libido dominandi as the dispositional foundation of masculine domination and some related categories (libido sciendi, libido academica, illusion dominandi).

That said, however, several critical remarks have also been formulated in the 17 years since the publication of Masculine Domination. Most of them find the book wanting in providing adequate empirical grounds for the statements $^{3}$. As Wallace (2003) puts it:

The sole "data" that informs Masculine Domination comes from anthropological information about the Kabyle society (a Mediterranean ethnic group) that Bourdieu gathered in the 1960s and a reading of Virginia Woolf's To the Lighthouse. By comparison with the thoroughness of his earlier work, Masculine Domination seems a brisk treatment of a subject that does not have Bourdieu's full attention. (...). As Terry Lovell (one of Bourdieu's most frequent and incisive critics) points out, "it is not always possible to know when [Bourdieu] is restricting his observations to the particular case of Kabyle society, when he is extending them to encompass the whole Mediterranean culture of honour/shame, including that of the modern period, and when he is offering universal generalizations (p. 20).

Undoubtedly, as Toril Moi writes (Moi 1991, p. 1033) "Bourdieu's empirical data are almost exclusively from his investigations among the Kabyle people of Algeria carried on in the 1950s which he has not updated or put to self-reflection". This makes Anne Witz accuse him of "dubious 
gender anthropology" (Witz 2004, p. 211). Particularly defective are his concrete references to late 20th century developments; ignoring these does reduce the relevance of the author's ambition to provide a broad historical horizon. This neglect of data is unusual for Bourdieu whose best works (for example Bourdieu 1984, 1989, 1992, 1993) are characterised by a sophisticated interpretation of subtle qualitative and quantitative variables. In short, it is not unfounded to suspect that in this work he only collected the arguments that would substantiate his preconceived thesis.

Another group of critical remarks charge the author with "determinism" and "pessimism", referring to a problem often raised in the critical interpretation of the whole Bourdieusian oeuvre. Some critics say Bourdieu's thinking is characterized by a "hyperfunctionalist", extreme structuralism (Joas \& Knöbl, 2011, p. 25) ${ }^{4}$; others, more politely, opine that "the author is more at home in analyzing the specificities of reproduction than those of social change" (Perrot et al., 1999, p. 209). Again some claim that "he overemphasises the significance of order and structure" (Skeggs 2004, p. 30) while some more poignant critics (Chambers, 2005) charge that "he rules out social change":

Parts of Bourdieu's analysis also imply that it will be difficult if not impossible for us even to conceptualise radical change, for he asserts that women living under patriarchy lack the cognitive resources to do so (Bourdieu 2001, p. 35, 2000, p. 170). Such a conclusion is problematic for it seems to rule out social change, and conflicts with the fact that change does occur, sometimes as the result of radical theorizing, for example of feminists about and against patriarchy. Bourdieu's contention that change in consciousness also requires change in the underlying social structures does have some force (p. 334).

There are critics who think that "the living conditions, practices, views and struggles of women today are not reflected at all in Bourdieu's text, which instead paints the picture of a gender order so completely doxic and closed that it seems almost totalitarian" (Krais, 2006). Here is the root of his pessimism, for a viewpoint that "his view of the perpetual reproduction of class-based inequality appears to leave little prospect that things will get better" (Joas \& Knöbl, 2011, p. 29). Although Bridget Fowler (the most 
sympathetic of British feminists toward Bourdieu's theory) stresses that Bourdieu's praxis theory is not totally deterministic, for in the final analysis people always have the possibility of reflection ${ }^{5}$, she still takes the view that Masculine Domination cannot grasp the periods of the transformation of patriarchic structure with due subtlety, and is particularly defective in the analysis of changes in the period of capitalist modernity (Fowler, 2003).

In addition, another group of critical remarks, related to the above-cited ones, argue that the author fails to refer to the literature on gender studies. "There is something frustrating about the ease and briskness with which Bourdieu dismisses whole schools of feminist thought" - argues Wallace (2003). Some critics acidly note that for the lack of citations, for the gross references and ambiguous allusions Bourdieu's dissertation would not pass the test in the first year of a $\mathrm{PhD}$ course (Mathieu, 1999). According to Lovell (2001),

Julia Kristeva and Luce Irigaray share a footnote in the 1990 version in which they are summarily dismissed as essentialist - a familiar charge, but one against which defences have been mounted (Grosz, 1989; Whitford, 1991). Even this backhanded acknowledgement has disappeared by 1998. Bourdieu's lack of engagement with those who already occupy the well-tilled 'field' of gender studies is quite remarkable (p. 44).

Several reviewers propose that when a sociologist in a dominant position, who happens to be male, almost perfectly ignores the bulk of feminist and gender literature in a work on gender themes, and thus impairs the significance of the female agent's history-forming power, he does not only represent the historical processes in a false light but also serves the symbolic reproduction of masculine domination (Lagrave, 2003, pp. 316317). As Beate Krais (2006) puts it:

To reconstruct the standpoints of others - in this case, of women Bourdieu would have had to do a thorough reading of the feminist research, which would have meant recognizing his feminist colleagues as 'equal players' in the intellectual field. Instead, he limited himself to his two 'extreme cases': his old material from Kabylia, and Virginia Woolf's description of a bourgeois British family at the beginning of the $20^{\text {th }}$ century (in her novel To the 


\section{Hadas - The Tricky "True Object"}

Lighthouse, 1927), arguing that this approach could overcome the familiarity of the gender order and achieve the objectifying distance needed for the analysis. (...) It is difficult to understand why Bourdieu - who in his other works emphasizes the importance of symbolic conflict and struggle - pays only cursory attention to the symbolic struggles over the gender order. (...) Apparently, it is difficult even for critical male social scientists to reflect upon their own masculine position. On the other hand, critical female scientists often seem to share a similar blind spot as regards their own position, and a similar hesitance to accept the contributions of male colleagues who dare enter their territory - particularly those who represent strong analytical positions - like Bourdieu (pp. 123124).

True enough: Bourdieu primarily calls feminist historiography to account for the study of institutions contributing to the maintenance of permanence, and by this rhetorical device he underestimates the importance of the agency of the feminist movement and the scientific reflection upon it. As he (Bourdieu, 2001) writes,

a history of women (...) cannot be content, for example, to record the exclusion of women from this or that occupation, this or that branch or discipline; it must also take note of and explain the reproduction both the hierarchies (occupational, disciplinary, etc.) and of the hierarchical dispositions which they favour and which lead women to contribute to their own exclusion from the places from which they are in any case excluded (p. 83).

It can be added that Masculine Domination reflects minimally on a few authors of feminist literature, but wholly ignores the representatives of the Studies on Men and Masculinities, making no attempt to ascribe the least importance to the plurality and differentiation of masculinity by involving in his analysis such key categories as Connell's hegemonic masculinity (Connell, 1996), Brittan's concept of "masculinism" (Brittan, 1989) or Whitehead's (2002) masculine subjectivity. Nor is he interested in looking at forms of "masculine bonding" that is, different forms of connection and cooperation between men (clubs, pubs, sports communities, the army), 
although this theme has become unavoidably institutionalised in AngloSaxon social historiography (Tosh, 1994).

\section{School, Family, State and Church: Institutions of Permanence?}

In the new chapter of the book, aiming to set "the historical labour of dehistoricisation", Bourdieu declares that "the major change has doubtless been that masculine domination no longer imposes itself with the transparency of something taken for granted. Thanks, in particular, to the immense critical effort of the feminist movement" (Bourdieu, 2001, p. 88). By referring to the increased access to secondary and higher education, waged work, public sphere, the degree of distancing from domestic tasks and reproductive functions, he also mentions "the substantive transformations seen in the conditions of women, especially in the most advantaged social categories" (Bourdieu, 2001, p. 88). However, as we have seen earlier, his main thesis is that "the structure of the gaps is maintained" between men and women (Bourdieu 2001, p. 91), and that "women have in common the fact that they are separated from men by a negative symbolic coefficient" (Bourdieu, 2001, p. 93). He defines the study of social institutions (church, state, school, family) sustaining continuity as the primary task of the approach to "the history of women" (Bourdieu, 2001):

In fact, it is clear that the eternal, in history, cannot be anything other than the product of historical labour of externalisation. It follows that, in order to escape completely from essentialism, one should not try to deny the permanences and the invariants, which are indisputably part of historical reality, but, rather, one must reconstruct the history of the historical labour of dehistoricisation, or, to put it another way, the history of the continuous (re)creation of the objective and subjective structures of masculine domination. (...) Historical research cannot limit itself to describing the transformations over time of the conditions of women, or even the relationship between the sexes in the different epoch. It must aim to establish, for each period, the state of system of agents and institutions - family, church, state, educational system, etc., which, with different weights and different means at different times, have 
helped to remove the relations of masculine more or less completely from history" (pp. 82-83).

The question can be raised whether the school, the family, the state and the church have contributed, as it is claimed, to the maintenance of permanence. The most often mentioned institution by Bourdieu (2001) is the school ${ }^{6}$ :

The educational system, even when it had freed itself from the grip of church, continued to transmit the presuppositions of the patriarchal representation (based on the homology between the men/women relationship and the adult/child relationship) and, perhaps most importantly, those that are inscribed in its own hierarchical structures, all sexually characterized, between the various schools and faculties, between the disciplines ('soft' or 'hard' - or. closer to the original mythical intuition - 'desiccating'), between specialisms, that is, between ways of being and ways of seeing, or seeing oneself, one's aptitudes and inclinations, in short, everything that combines to form not only social destinies but also self-images (p. 86).

Taking a short-term perspective one may argue that women may primarily be successful in traditionally feminine, provident occupations, their pay is lower than men's and that in most segments of the labour market the dominant positions are taken by men. When, however, the theme is looked at in a complex long-term historical context, it is particularly questionable that in the western world the school reproduces the gender differences in the long run. It cannot be ignored (and this fact is so obvious that it needs no references to prove) that while prior to the $19^{\text {th }}$ century only daughters of upper-class families could have systematic private tutoring for many years, from the late $19^{\text {th }}$ century women could also take part, first in elementary and intermediate levels of public education and from the $20^{\text {th }}$ century in higher education as well.

The long-term perspective clearly shows that while a hundred and fifty or two hundred years ago the overwhelming majority of women were locked out of the institutions of education, from the second half of the $20^{\text {th }}$ century they have been present at all educational levels just like men. What is more, at the onset of the $21^{\text {st }}$-century women have a higher rate of 
schooling (and better results) in the younger generations than men. (It is not necessary to embark upon the impact of this phenomenon on the labour market and the division of work in the household). In other words: while the schools of the $19^{\text {th }}$ century and earlier were almost exclusively peopled by men (as teachers, students and auxiliary staff), by the end of the $20^{\text {th }}$ century, the structural gap between genders had disappeared. Consequently, the institution of education does not maintain the permanence of masculine domination, but serves the power balance between genders!

Having a look at the subject index of the French edition, it can be found that the notion "family" used on 13 pages (Bourdieu, 1998, p. 138), but the relevant quotations are far shorter than those about school. Although it is mentioned that some changes have occurred but Bourdieu (2001) puts the emphasis on the factors of permanence:

The family undoubtedly played the most important part in the reproduction of masculine domination and the masculine vision, it is here that early experience of the sexual division of labour and the legitimate representation of that division, guaranteed by law and inscribed in language, imposes itself (p. 85).

Oddly enough, the validity of this strong statement is considerably decreased by being the only sentence in the whole book about the role of the family in the reproduction of masculine domination! ${ }^{7}$. Bourdieu mentions Chodorow's (1978) famous book, but he fails to refer to a single researcher of family history. It may then be not farfetched to state that his idea of the correlation between family and masculine domination is tendentious and sketchy ${ }^{8}$. That is particularly conspicuous against the background of immense literature on the theme produced in the past half a century.

One of the most relevant of these traditions is the "Sentiments Approach" among the followers of which there is a consensus that before the $17^{\text {th }}$ century marriage was an economic, production-oriented and procreative unit in which the sexual act was not aimed at procreation but was considered as a sin (Aries, 1960; Shorter, 1976; Flandrin, 1979; Anderson, 1980; Stone, 1982). The prime aim of marriage was to (re)produce fortune and social position from one generation to the other. According to Stone (1982) and Flandrin (1979), in this early period, there 
were no modern-type emotional ties between family members. From the $17^{\text {th }}$ century onwards important changes began. As Philippe Aries demonstrated in his often-quoted book (Aries, 1960), in aristocratic and highly educated families attitudes towards children gradually changed: specific children's dress, toys, readings, games, and pedagogical programmes were devised for them, which means that the conditions for the emergence of "childhood" as a separate life period starts to be created. The "birth" of childhood entailed the parallel emergence of parenthood, that is, the development of the modern institution of maternal and paternal activities requiring the internalisation of appropriate emotions, duties, and goal-oriented educational tasks.

All of these authors point out that the significance of the intimate sphere is upgraded in this process: husbands spend more time at home, in the company of their wives. "What really distinguishes the nuclear family (...) from other patterns of life in Western society is a special sense of solidarity that separates the domestic unit from the surrounding community" - writes Shorter in his groundbreaking "Making of the Modern Family" (Shorter, 1976, p. 205). Or, as Anderson (1994) formulates it: "from the second half of the $18^{\text {th }}$ century "domesticity had reached its zenith and spread to other social groups. (...) The home came to be seen as a haven, a retreat from the pressures of a capitalistically oriented competitive world" (Anderson, 1994, p. 47). Although it is still the man who is the master of the household, the strengthening of emotional ties in family life softens the rigidity of patriarchal dominance. With the decrease in family size and the increase in the importance of the child-rearing mother the centre of family life moves to use Mary Ryan formulation - "from patriarchal authority to maternal affection" (Ryan, 1981, p. 102). The invention of modern motherhood (Dally, 1982; Badinter, 1981) and the identification of maternal activity with the essence of femininity mean that the growing legitimacy of the woman - paradoxically - will be rooted in the "mysterious," "natural" and "irrational" otherness of the "weaker sex".

Bourdieu simply ignores perhaps the most momentous social change of the last third of the $20^{\text {th }}$ century: the transformation of intimacy. He seems to overlook that from the 1960s something changed irrevocably in the Western world: a growing number of women have gained legitimate control of their own bodies. That does not merely mean their right to decide about 
abortion, but also their growing claim to the right of sexual satisfaction ${ }^{9}$. Consequently, whilst the influence of the female agent increases, the legitimacy of masculine violence monopoly decreases. This process implies that men have to control their violent impulses in the intimate sphere and to incorporate dispositional elements that were associated with women in previous millennia. Consequently, the institution of the family does not maintain the permanence of masculine domination, but serves the power balance between genders!

According to Bourdieu, the third key protagonist in dehistoricization and the maintenance of masculine domination is the state, with 9 loci in the index (Bourdieu, 1998, p. 138). As he writes (Bourdieu, 2001):

[The state] has ratified and underscored the prescriptions and proscriptions of private patriarchy with those of public patriarchy inscribed in all the institutions charged with managing and regulating the everyday existence of the domestic unit. Without reaching the extremes of paternalist, authoritarian states (such as France under Pétain or Spain under Franco), full-scale realizations of the ultra-conservative vision which makes the patriarchal family the principle and model of the social order interpreted as moral order, based on the absolute pre-eminence of men over women, adults over children, and on identification of morality with the strength, courage and self-control of the body, the seat of temptations and desires, modern states have inscribed all the fundamental principles of the androcentric vision in the rules defining the official status of citizens (p. 87).

Unfortunately, Bourdieu does not differentiate between the mid-20 ${ }^{\text {th }}$ century rightwing authoritarian states and the late $20^{\text {th }}$ century, leftist social democratic "provident" states, among other things. Nor does he find it important to reflect upon the historically-culturally determined differences between, say, the Italian or Swedish state structures. And he also fails to consider how the functions of the state are connected to the other institutions, the family, school and church(es) in the long run - although several great narratives are at his disposal. The strongest thesis is offered by Norbert Elias' opus magnum (Elias, 2000), in which the long-term transformations in the behaviour of the secular upper classes in the West are put under scrutiny. The kernel of the Eliasian argument is that upon 
external social pressures, people develop self-control mechanisms which suppress "uncivilized", animal-like behavioural elements based on violence. These suppressions function as feelings of shame, confusion and embarrassment. Hence, these feelings are not natural endowments but the internalised products of social-historical circumstances, namely that violence control is to be traced to the emerging state monopoly of violence and taxation.

Through the formation of monopolies of force, the threat which one person represents for another is subject to stricter control and becomes more calculable. Everyday life is freer of sudden reversals of fortune. Physical violence is confined to barracks, and from this store-house, it breaks out only in extreme cases, in times of war or social upheaval, into individual life. (...) When a monopoly is formed, pacified social spaces are created which are normally free from acts of violence (Elias, 2000, pp. 369-372).

In volume two of the book, Elias devotes a chapter ("Dynamics of Feudalization") to the increase of population after the great migration, the internal expansion of society, the formation of new social organs and instrument, among other things (Elias, 2000, pp. 195-256). In chapter two of volume 2 ("On the Sociogenesis of the State") he gives a systematic analysis of the interdependencies between state formation and civilizing process (Elias, 2000, pp. 257-362). If we take seriously the Eliasian thesis according to which,

The rise in the division of functions also brings more and more people, larger and larger populated areas, into dependence on one another; it requires and instils greater restraint in the individual, more exact control of his or her affects and conduct, it demands a stricter regulation of drives and - from a particular stage on - more even self-restraint (Elias, 2000, p. 429).

We might argue that whilst the influence of the female agent increases, the legitimacy of masculine violence monopoly decreases. To put it differently: according to Elias, the long-term psychologisation and pacification of social life imply that men have to control their violent impulses in different social spheres (including the intimate sphere), and to 
incorporate dispositional elements that were associated with women in previous centuries. Consequently, in the long run, the institution of state does not maintain the permanence of masculine domination, but serves the power balance between genders!

Let us finally say something about the church! Three continuous sentences can be found in the book (Bourdieu, 2001) about this institution (the index of the French edition refers to six pages where the concept of "church" appears):

As for the church, pervaded by the deep-seated anti-feminism of a clergy that was quick to condemn all female offences against decency, especially in matters of attire, and was the authorized reproducer of pessimistic vision of women and womanhood, it explicitly inculcates (or used to inculcate) ${ }^{10}$ a familialist morality, entirely dominated by patriarchal values, with, in particular, the dogma of the radical inferiority of women. In addition, it acts, more indirectly, on the historical structures of the unconscious, notably through the symbolism of the sacred texts, the liturgy and even religious space and time (p. 85).

He bases his arguments on three references, each dealing with a specific implication of Catholicism ${ }^{11}$. Unfortunately, these incidental references are not sufficient even for a sketchy outline of the historical dynamism of Catholic Church and Catholicism, just as the allusion to the conditions four or five centuries earlier does not have the force of evidence if valid statements about the role of the church in the maintenance of masculine domination are to be substantiated. Undoubtedly, a highly complex set of phenomena is to be considered, for the Roman Catholic Church has changed thoroughly in Europe in the past centuries. Moreover, different focal points and phenomena would have to be chosen for study when the topic is, let's say, the Italian, the Irish, or the Polish Catholic Church, or, for that matter, some historical formation of eastern Catholicism. Then there is the row of fundamental changes triggered off by the Reformation, which also raises the question of conflicts and distinctions among the Protestant churches, in addition to the Catholicism Vs Protestantism opposition.

Evidently, the Finnish Lutheran, British Anglican or German Calvinist churches (to mention randomly a few) are far away from each other in 
historical dynamism, and each could only be comprehended in its complex relation to the given social structure. Regrettably, Bourdieu does not deal with the long-term transformation of social relations arising from the Reformation and wars of religion even in passing; nor does he allude to the enormous literature that has been created to illumine the correlations between the Protestant ethic, this-worldly asceticism, the inner differentiation of the church, inchoate capitalism, the institutions incorporating rational competition, and the historical variations of masculine domination. The name of Max Weber only crops up once in the book - in a wholly different context.

Even without an in-depth analysis, however, it can be contended that out of the four institutions mentioned by Bourdieu these are the Christian churches that would provide the best-grounded arguments to prove that notwithstanding all their changes and inner differentiation - they have contributed most to the reproduction and maintenance of masculine domination in the long run. To put it more cautiously, out of the four institutions it is the church in which the stoutest resistance to the forces of women's emancipation can be expected to this day. At the same time, it ought also to be considered in a complex analysis, besides the demonstrable decrease in the power of masculine domination in the churches in the long run, that under the conditions of secularising modernity it is the church of the four institutions whose social influences has decreased most with the passing of time.

\section{Vision on History in Masculine Domination}

The true object of a history of relations between the sexes is thus the history of the successive combinations (...) of structural mechanisms (such as those which ensure the reproduction of the sexual division of labour) and strategies which, through institutions and individual agents, have perpetuated the structure of relations of domination between the sexes, in the course of a very long history, and sometimes at the price of real or apparent changes (Bourdieu, 2001, pp. 83-84). 
The question is whether Bourdieu's above statements can be accepted or not. It is possibly tenable that from pre-modern societies represented by Kabyle peasants through the Bloomsbury circle to the $21^{\text {st }}$ century certain elements of masculine domination bridging ages, social groups and diverse economic conditions, can be discerned. Further, it can be a justifiable ambition for a researcher to try and consider forces that provide for the maintenance of relations of domination in addition to the exploration of the factors of transformation. The author of this paper is also inclined to accept that changes first take place in the upper social strata (but - precisely in view of Bourdieu's Distinction - it can be added that the norms, forms of taste and patterns of living that crystallize and become legitimate in the upper crust sooner or later ooze downward into the lower social strata as well). What is more, Bourdieu's theoretical statement that habitus is inseparable from the structure can be regarded of key significance, too, as it was mentioned earlier. That is to say, a study of social praxis and hexis can and should take into account gender(ed) habitus as well. However, it seems to be a problematic statement that gender specificities should enjoy extraordinary autonomy:

It is indeed astonishing to observe the extraordinary autonomy of sexual structures relative to economic structures, of modes of reproductions relative to modes of production. The same system of classificatory schemes is found, in its essential features, through the centuries and across economic and social differences, at the two extremes of the space of anthropological possibles, among the highland peasants of Kabylia and among the upper-class denizens of Bloomsbury (Bourdieu, 2001, p. 81).

This is not only logically indefensible (for if habitus is inseparable from the structure, then changes in the structure will inevitably entail changes in habitus). Bourdieu himself writes, that

dispositions (habitus) are inseparable from the structures (habitudines, in Leibniz' sense) that produce and reproduce them, in both men and women, and in particular from the whole structure of technical and ritual activities that is ultimately grounded in the structure of the market in symbolic goods (Bourdieu, 2001, p.42). 


\section{Hadas - The Tricky "True Object"}

On the basis of this claim, it seems to be axiomatic that, conditioned by the transformation of the whole structure, gender(ed) habituses are also changing in the long run. The above quotation also contradicts Bourdieu's practice of analysis: a whole row of the author's excellent empirical works proves that changes in the macrostructure or the structure of the field are intertwined with the habitual changes of the agents (Bourdieu, 1984, 1992).

That is to say that Bourdieu uses a methodological trick at this point in order to be able to state that while economic and social structures change, gender(ed) structures determined by masculine domination are maintained or remain unaltered. The trick is that Bourdieu highlights changes in examining one type of social interdependencies and concentrates on permanence when looking at another type of social interdependencies. Or, the streaming river is compared to the riverside cliffs and not to another streaming river. Hence, it is justified to suspect that the argument is governed, not by the logic of empirical observations, but by the ambition to legitimate or illustrate certain preconceptions. If the subject is constructed in such a tricky manner, no scientific debate can be carried out about whether the "structure of the gap" between men and women is maintained or not by the end of the $20^{\text {th }}$ century, because one can always find arguments torn from their complex historical context that may support the permanence of masculine domination, and others that support its changeability.

What Bourdieu practically does in Masculine Domination when he speaks of the "power of the structure" and the "symbolic negative coefficient" is paradigm expansion, for he applies his thesis crystallised in its most sophisticated form in his Distinction (1984) about the displacement of social structure. In this book he analyzes the interrelations between different social classes in a three-dimensional space: examining the quantity of capital possessed by the classes and class fractions; the structure of this capital (the rate of economic and cultural capitals, the re-conversion strategies between different types of capital); and the temporal changes of these two factors. In a sophisticated and witty critical analysis of the French society of the ' $50 \mathrm{~s}$ and $70 \mathrm{~s}$ he writes (à propos the displacement of schooling rates of 16-to 18-year-olds between 1954 and 1975):

Re-conversion strategies are nothing other than an aspect of the permanent actions and reactions whereby each group strives to 
maintain or change its position in the social structure, or more precisely - at a stage in the evolution of class societies in which one can conserve only by changing - to change so as to conserve. Frequently the actions whereby each class (or class fraction) works to win new advantages, i.e., to gain an advantage over the other classes or so, objectively, to reshape the structure of objective relations between the classes (the relations revealed by the statistical distributions of properties), are compensated for (and so cancelled out ordinally) by the reactions of the other classes, directed toward the same objective. In this particular (though very common) case, the outcome of these opposing actions, which cancel each other by the very countermovements, which they generate, is an overall displacement of the structure of the distribution, between the classes or class fractions, of the assets at stake in the competition. (...) Thus, by an apparent paradox, the maintenance of order, that is, the whole set of gaps, differences, differentials, ranks, precedents, priorities, exclusions, distinctions, ordinal properties, and thus of the relations of order which give a social formation its structure, is provided by an unceasing change in substantial (i.e., non-relational) properties. This implies that the social order established at any given moment is also necessarily a temporal order, an "order of successions", as Leibniz put it, each group having as its past the group immediately below and for its future the group immediately above (Bourdieu 1984, p.157-163).

This lengthy quotation also illustrates the strategic specificity of Bourdieu's paradigm-extension: in Masculine Domination all he does is to replace class by gender, and class habitus by gender(ed) habitus. When he discusses "the constancy of habitus", "the negative symbolic coefficient by which women are separated from men", the "permanence in and through change", or the "strength of the structure", he extends his theory about the displacement of the social structure to the displacement of the men/women relationship ${ }^{12}$.

It is beyond this criticism to review Bourdieu's reproduction theory in detail. Let's merely note that while this theory is more or less adequate for the period between the last third of the $19^{\text {th }}$ and the last third of the $20^{\text {th }}$ centuries, it becomes problematic when it is applied to late-modern Western societies (and it is somewhat already problematic for the French society of 


\section{Hadas - The Tricky "True Object"}

the 1960s-1970s). Should we accept that "the social order established at any given moment is also necessarily a temporal order, an order of successions, each group having as its past the group immediately below and for its future the group immediately above", we would be at a loss viewing the radical transformations that have fundamentally restructured social relations in multicultural Western societies over the past few decades ${ }^{13}$.

Hence, contrary to Bourdieu's claims, a consistent long-term social historical perspective would clearly reveal that, compared to earlier centuries the structurally conditioned social position of women had shifted towards emancipation in Europe; the female agent was gradually entering the stage of history, attaining a lot of the formulated demands: women defined by their motherhood became the protagonist of lots of $19^{\text {th }}$ century disputes over population - both as agents and as subjects. All this can be interpreted as the increase in the relative power of the female agent. In France, for instance, threatened by Bismarck's Germany, "depopulation" and "dénatalité" were considered to be a "social plague" and maternity became an object of many and contradictory comments" (Cova, 1991, p. 119). The basis for this moral panic was that "whereas France had been the most densely populated country in Europe, by 1918 it ranked fifth in population. Many 'repopulaters' accused the feminists of being responsible for the declining birth-rate. The strategy of the feminist movement as a whole was to utilize that apparent demographic danger and the glorification of motherhood as a weapon in the struggle for the rights of mothers". Maria Martin, the editor of Journal des femmes, wrote in 1896: "If you want children, learn to honour the mothers" (Cova, 1991, pp. 119-120).

\section{Conclusion}

After comparing the Masculine Domination's two versions, and summing up the main claims of their critical reception, this paper intended to question the key statements of Pierre Bourdieu's book, according to which the school, the family, the state and the church would reproduce, in the long run, masculine domination. It was argued that, with the exception of the church, the three other institutions had not maintained the permanence of masculine domination, but served the power balance between genders. It was also intended to identify the methodological trick of the Bourdieusian 
vision on history, namely that, metaphorically speaking, he had compared the streaming river to the riverside cliffs. It was argued that while discussing "the constancy of habitus" and the "permanence in and through change", or the "strength of the structure", Bourdieu had extended his paradigm about the displacement of the social structure to the displacement of the men/women relationship.

When, in opposition to Bourdieu's approach, the analysis of gender relations is put into the historical context of complex social interdependencies, the conclusion may be drawn that masculine domination is not of universal validity but its structural weight and character have fundamentally changed in the long run. Around the $17^{\text {th }}$ century the forms of masculinities and the nature of masculine domination began to be subject to considerable change in Europe: the fighting, knightly masculinity based on the archaic libido dominandi was gradually replaced by a competitive, throughout psychologised, pacified masculinity which permeated both the public and the intimate spheres and which later ramified into further subvariants.

Women's emancipation in the West was closely connected to one of the most important specificities of modernity, the potential of the fulfilment of future-oriented change. The success of feminism and female emancipation was an eloquent proof of this potential. In the long run, the masculine habitual centre gradually shifted from a social practice governed by the drives of physical violence to the praxis of rivalry and symbolic violence. This process implied that men had to control their violent impulses, and to incorporate dispositional elements that were associated with women in previous millennia. In other words, honour-based masculinity was bridled and the hunting, duelling, sword wielding warrior ("noblesse d'épée") gradually transformed into a courtier ("noblesse de robe") (Elias, 2000; Nye, 1998). It is regrettable that this fundamental structural change was overlooked by Bourdieu, who, in his Masculine Domination, overemphasized the importance of permanence and the symbolic aspect of violence.

\section{Notes}

${ }^{1}$ Seemingly a trivial matter, it might be also of importance: in the contents of the French edition, the post-scriptum is printed as if it were the last chapter of the third part. By 


\section{Hadas - The Tricky "True Object"}

contrast, the contents of the English version only include the three main parts without the subchapters. The lucidity of the argumentation is gravely marred thereby.

${ }^{2}$ As a sign of considerable self-restraint, Bourdieu omitted this passage from his book.

${ }^{3}$ The author of this text agrees with the overwhelming majority of these critical comments. If not so, a note will be made.

4 This critique seems to be an overstatement because Bourdieu, in his best (referred to above), is capable of producing sophisticated empirical analyses that surpass schematic hyperfunctionalism.

${ }^{5}$ Unlike Fowler, the author of this article thinks that although Bourdieu's theory of praxis does try to shun the trap of determinism, it defines less the (self)reflexivity of the agents as its main means but rather, stresses partly the freedom of (limited) improvisation ensured by habitus and partly the importance of the translational reproduction of the social structure.

6 The term ,school" are used on 10 pages according to the index of the French edition (Bourdieu 1998, p. 137). These quotations are significantly longer than those referring to the other three institutions. (The "education"-concept is missing from the index.).

${ }^{7}$ There are two more sentences (!) in the book concerning the family (in association with an article published in American Psychologist in 1977, entitled "Changes in Family Roles, Socialization, and Sex Differences"), but, interestingly, these sentences concern changes not permanence in the family (Bourdieu, 2001, p. 89).

${ }^{8} \mathrm{He}$ ignores even his earlier research: although he devoted a long article to changes in family structures (Bourdieu, 1993b), but, interestingly, he does not take it into account in this book.

9 To use Giddens' term: sexuality is gaining plasticity:

Plastic sexuality is decentred sexuality, freed from the needs of reproduction...) can be moulded as a trait of personality and thus is intrinsically bound up with the self. At the same time - in principle - it frees sexuality from the rule of the phallus, from the overweening importance of male sexual experience." (Giddens 1992, p. 2). Giddens sets the new "emotional order" in the focus of attention which had a crucial role in the equalization of power relations between men and women in Western Modernity. He wishes to grasp this emotional order using three key concepts: "pure relationship", "plastic sexuality", and "the ethos of romantic love". Pure relationship designates a "relationship of sexual and emotional equality" (Giddens 1992, p. 2), plastic sexuality means a "decentred sexuality, freed from the needs of reproduction" and "from the rule of the phallus", the ethos of romantic love, the harbinger of the pure relationship, "presumes that a durable emotional tie can be established with the other on the basis of qualities intrinsic to that tie itself". According to Giddens, although this ethos helps "to put women 'in their place' - the home", its emergence "can be seen as an active, and radical, engagement with the 'maleness' of modern society (Giddens, 1992).

${ }^{10}$ In French: ,, inculque (ou inculquait) explicitement une morale familialiste”. This bracket unveils that the present and the past are intermixed, i.e. the kernel of the matter, historicity is not taken into account.

${ }^{11}$ One discusses the "expiatory ethos" of the Spanish church, the second is a study of French female mystics, and the third embarks on the representation of women in $16^{\text {th }}$ century ecclesiastic art. From the latter he gives a citation in a footnote, which contains the far from surprising statement that the $16^{\text {th }}$ century clerical books and sermons were written by men, and not by women. 
12 One could go back even to earlier times and find that his thesis put forth in Distinction was already formulated from the beginning of his career. Significantly, in "La sociologie de l'Algérie", which is Bourdieu's first book written in 1958, there is a chapter entitled "La permanence par le changement" [Permanence by change].

${ }^{13}$ If the thesis of the overall displacement of the social structure would be extended from a national to an international context, it could be argued that the structural gap between genders is being reproduced as part of the Global North / Global South-divide (Hochschield \& Ehrenreich, 2004). Bourdieu ignores this international dimension in this book.

\section{References}

Anderson, M. (1994). Approaches to the History of the Western Family. The Economic History Society. London: Macmillan.

Aries, P. (1960). L'Enfant et la vie familiale sous l'Ancien Régime. Paris: Plon.

Badinter, E. (1980). L'amour en plus: histoire de l'amour maternel (XVIIeXXe siècle). Paris: Flammarion.

Bartky, S. L. (1990). Feminity and Domination. New York: Routledge

Bourdieu, P. (1984). Distinction. London: Routledge and Kegan Paul.

Bourdieu, P. (1989). La noblesse d'état. Paris: Minuit.

Bourdieu, P. (1990). La domination masculine. Actes de la recherche en

science sociales. 84(1), 2-31. doi:10.3406/arss.1990.2947

Bourdieu, P. (1992). Les regles de l'art. Paris: Seuil.

Bourdieu, P. (1993a). La misere du monde. Paris: Seuil.

Bourdieu, P. (1993b). À propos de la famille comme catégorie réalisée.

Actes de la recherche en science sociales, 100(1), 32-36.

doi:10.3406/arss.1993.3070

Bourdieu, P. (1998). La domination masculine. Paris: Seuil.

Bourdieu, P. (2000). Pascalian Meditations. Cambridge: Polity Press.

Bourdieu, P. (2001). Masculine Domination. Cambridge: Polity Press.

Brittan, A. (1989). Masculinity and Power. Hoboken, NJ: Wiley.

Butler, J. (1990). Gender Trouble. New York: Routledge.

Chambers, C. (2005). Masculine domination, radical feminism and change.

Feminist Theory, 6(3), 325-346. doi: 10.1177/1464700105057367

Chodorow, N, J. (1978). The Reproduction of Mothering: Psychoanalysis

and the Sociology of Gender. Berkeley: University of California Press.

Connell, R. W. (1995). Masculinities. Cambridge: Polity Press. 
Cova, A. (1991). French feminism and maternity: theories and policies 1890-1918. In G. Bockm \& P. Thane (Eds.), Maternity and Gender Policies. Women and the Rise of the European Welfare States, 1880s1950s (pp. 119-137). London: Routledge.

Dally, A. (1982). Inventing Motherhood. London: Burnett.

Eisner, M. (2003). Long-Term Historical Trends in Violent Crime. Crime and Justice, 30, 83-142. Retrieved from http://www.jstor.org/stable/1147697

Elias, N. (2000). The Civilizing Process. Sociogenetic and Psychogenetic Investigations. London: Blackwell Publishers.

Giddens, A. (1992). The Transformation of Intimacy. Cambridge: Polity Press.

Flandrin, J. L. (1979). Families in Former Times. Cambridge University Press, Cambridge.

Fowler, B. (2003). Reading Pierre Bourdieu's Masculine Domination:

Notes towards an Intersectional Analysis of Gender, Culture and Class.

Cultural Studies, 17 (3/4), 468-494.

doi:10.1080/0950238032000083908

Grosz, E. (1989). Sexual Subversion: Three French Feminists. Sydney:

Allen and Unwin.

Hochschield, A. R., \& Ehrenreich, B. (Eds.). (2004). Global Women.

Nannies, Maids, and Sex Workers in the New Economy. New York:

Henry Holt and Company.

Joas, H., \& Knöbl, W. (2011). Between structuralism and Theory of

Practice: The Cultural Sociology of Pierre Bourdieu. In S. Susen \& B. S.

Turner (Eds.), The Legacy of Pierre Bourdieu (pp.1-33). London:

Anthem Press.

Krais, B. (2006). Gender, Sociological Theory and Bourdieu's Sociology of

Practice. Theory, Culture \& Society, 23(6). 119-134.

doi:10.1177/0263276406069778

Lagrave, R. M. (2003). La lucidité dés dominées. In P. Encrevé \& R. M.

Lagrave (Eds.), Travailler avec Bourdieu (pp. 313-329). Paris:

Flammarion.

Lovell, T. (2001). Thinking feminism with and against Bourdieu. The

Sociological Review, 49(S1), 27-41. doi: 10.1111/j.1467-

954X.2001.tb03531.x 
Mathieu, N. C. (1999). Bourdieu et le pouvoir autohypnotique de la domination masculine. Paris: Les temps modernes.

MacKinnon, C. A. (1988). Feminism Unmodified. Cambridge: Harvard University Press.

Moi, T. (1991). Appropriating Bourdieu: Feminist Theory and Pierre Bourdieu's Sociology of Culture. New Literary Theory, 22(4), 10171049. doi:10.2307/469077

Nye, R. A. (1998). Masculinity and Male Code of Honor in Modern France. San Francisco: University of California Press.

Perrot, M., Sintomer, Y., Krais, B., \& Duru-Bellat, M. (1999). Autour du livre de Pierre Bourdieu, La domination masculine. Travail, genre et sociétés n. 1. Paris: CNRS.

Ryan, M. (1981). The Cradle of the Middle Class. Cambridge: Cambridge University Press.

Shorter, E. (1976). The Making of the Modern Family. New York: Basic Books.

Skeggs, B. (2004). Context and Background: Pierre Bourdieu's analysis of class, gender and sexuality. In L. Adkins \& B. Skeggs (Eds.), Feminism After Bourdieu. (pp-19-34). Oxford: Blackwell.

Stone, L. (1982). Family, Sex and Marriage in England 1500-1800. Harmondsworth: Pelican.

Thébaud, F. (2006). Propos d'historienne sur La Domination masculine. In P.H. Müller \& Y. Sintomer (Eds.), Pierre Bourdieu, théorie et pratique. Perspective franco-allemandes (pp. 175-190). Paris: La Découverte.

Tosh, J. (1994). What Should Historians do with Masculinity? Reflections on Nineteenth-century Britain. History Workshop Journal, 38, 179-202. Retrieved from http://www.jstor.org/stable/4289324

Wallace, M. (2003). A Disconcerting Brevity: Pierre Bourdieu's Masculine Domination. Postmodern Culture. 1/2003, 13(3).

doi:10.1353/pmc.2003.0027

Whitehead, S. (2002). Men and Masculinities: Key themes and new directions. Cambridge: Polity Press.

Whitford, M. (1991). Luce lrigaray: Philosophy in the Feminine. London: Routledge. 
240 Hadas - The Tricky "True Object"

Witz, A. (2004). Anamnesis and amnesis in Bourdieu's work: The case for a feminist anamnesis. In L. Adkins \& B. Skeggs (Eds.), Feminism after Bourdieu. (pp.211-223). Oxford: Blackwell.

Miklós Hadas is professor of sociology at the Corvinus University of Budapest, Hungary

Contact Address: Direct correspondence to Miklós Hadas at Corvinus University of Budapest, Institute of Sociology, 1093 Budapest, Fővám tér 8. Hungary, E-mail: miklos.hadas@ unicorvinus.hu 


\section{Hipatia Press}

Instructions for authors, subscriptions and further details:

\section{Mobile Masculinities: An Investigation of Networked Masculinities in Gay Dating Apps}

Nathian Shae Rodriguez ${ }^{1}$

Jennifer Huemmer ${ }^{2}$

Lindsey E. Blumell ${ }^{3}$

1) San Diego State University, United States

2) Texas Tech University, United States

3) Oxford Brookes University, England

Date of publication: October 21 $11^{\text {st }}, 2016$

Edition period: February 2017 - June 2017

To cite this article: Rodriguez, N. S., Huemmer, J., \& Blumell, L. E. (2016). Mobile Masculinities: An Investigation of Networked Masculinities in Gay Dating Apps. Masculinities and Social Change,5(3),241-267. doi: 10.17583/MCS.2016.2047

To link this article: http://doi.org/10.17583/MCS.2016.2047

\section{PLEASE SCROLL DOWN FOR ARTICLE}

The terms and conditions of use are related to the Open Journal System and to Creative Commons Attribution License (CC-BY). 
MCS - Masculinities and Social Change Vol. 5 No. 3 October 2016

pp. 241-267

\title{
Mobile Masculinities: An
}

\section{Investigation of Networked}

Masculinities in Gay Dating Apps

Nathian Shae Rodriguez

San Diego State University

Jennifer Huemmer

Texas Tech University

\author{
Lindsey Blumell \\ Oxford Brookes University
}

\begin{abstract}
This study argues that hegemonic masculinity is still prevalent as well as conciliatory to inclusive masculinity when applied to networked masculinities in homosexual spaces. The authors contend hegemonic masculinity is a macro-level process that informs micro-level processes of inclusive masculinity. Employing a textual analysis of 500 individual profiles in gay dating apps (Scruff, GROWLr, GuySpy and Hornet), findings indicate networked masculinities are informed by the two concepts. A resulting process of "mascing" is created and introduced in this study. Mascing in gay males to reinforces their own masculinity, while also maintaining masculine norms by seeking out masculine partners. The process is a form of policing that reinforces a masculine elite within the gay dating app community.
\end{abstract}

Keywords: mascing, gay dating apps, networked masculinities, hegemonic masculinity, inclusive masculinity, digital spaces, mobile, textual analysis 
MCS - Masculinities and Social Change Vol. 5 No. 3 October 2016

pp. 241-267

\title{
Masculinidades Móviles: Una
}

\section{Investigación de Masculinidades en \\ Red en las Gay Dating Apps}

Nathian Shae Rodriguez

San Diego State University

Jennifer Huemmer

Texas Tech University

\author{
Lindsey Blumell \\ Oxford Brookes University
}

\section{Resumen}

Este estudio sostiene que la masculinidad hegemónica está todavía muy extendida, también cuando hablamos de la masculinidad inclusiva en relación a las masculinidades en red concretadas en espacios homosexuales. Los autores sostienen que la masculinidad hegemónica es un proceso a nivel macro que incorpora los procesos micro de la masculinidad inclusiva. A través de un análisis de contenido de 500 perfiles individuales en diferentes app de citas gay (Scruff, GROWLr, GuySpy y Hornet), hemos hallado resultados que indican que las masculinidades en red son definidas a partir de dos conceptos. Un proceso al que hemos llamado "mascing". Mascing se refiere a los hombres homosexuales que refuerzan su propia masculinidad, manteniendo al mismo tiempo las normas masculinas con el objetivo de encontrar parejas también muy masculinas. De forma que este proceso es una forma de vigilancia que refuerza una élite masculina dentro de las app de la comunidad gay.

Palabras clave: mascing, gay dating apps, masculinidades en red, masculinidad hegemónica, masculinidad inclusiva, espacios digitales, móbiles, análisis de textos 


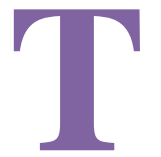

here has been an increase in the representations of gay males in mainstream media as well as an upsurge in gay-specific media. These portrayals, however, have depicted gay males as young, white, smooth bodied, muscled, good looking, educated, and holding professionals jobs with high incomes (Fejes, 2000; Poole, 2014); not too different from the typical depictions of heterosexual males in mainstream media. This constant media representation of an idealized masculinity influences social norms and gender identity expectations.

Similarly, due to the ubiquity of the Internet, people can perpetually connect through the use of mobile apps. There are numerous apps at the disposal of gay males who are searching for companionship, meaningful relationships or casual sex. Because gay men primarily utilize these apps for hooking up (either sexual or not) there is a paradox of convenience crafted amongst the users. According to Freeman (2014) these apps benefit users by saving time searching for other compatible males; potential partners are instantly and constantly available online. However, the apps also "create a society of oversharing, superficiality, and instant gratification. You are on the grid 24/7 and you must advertise yourself" (p.5).

Through an advertisement of sorts, men construct and display their masculinity on these digital spaces, specifically their user profiles (Payne, 2007). Masculinities are socially constructed and vary in degrees, with hegemonic masculinity being the most extreme (Connell, 1992; Demetriou, 2001). Hegemonic masculinity has typically been considered heterosexually constructed (Connell, 1995), but there are scholars who have identified a "homomasculinity" that mirrors that of hegemonic masculinity in gay males (Clarkson, 2006; Eguchi, 2009; Suresha, 2002; Ward, 2008). There is also a contention amongst other scholars that hegemonic masculinity is no longer a viable theoretical framework from which to examine masculinities due to a shift in hegemonic dominance (Anderson, 2015). The theoretical lens of inclusive masculinity reasons that a decrease in homohysteria has directly impacted masculinities, specifically among heterosexual males, and has stripped homophobia of its power to regulate masculinities (Anderson, 2015). 
We argue that these seemingly opposing theoretical foundations are actually conciliatory when applied to networked masculinities, specifically in homosexual spaces. Hegemonic masculinity involves a "pattern of practice" for performing a type of masculinity that naturalizes men's dominance over women (Connell \& Messerschmidt, 2005). Hegemonic masculinity is conceptualized as the normative patterns of performing masculinity as a gender rather than as an idealized identity or set of role expectations. These normative patterns are then held as the "most honored way of being a man" and all other male gender performances are examined within the framework of that standard (Connell \& Messerschmidt, 2005). Inclusive masculinity focuses on the amount of homophobia present (temporally and spatially) in order to regulate masculinities. Both theoretical frameworks were conceptualized based on heterosexual masculinities, however, what happens when these conceptualizations are applied to gay masculinities? We argue that both inform each other.

The current study examines how networked masculinities manifest in the user profiles of gay males using gay dating apps. Particularly, we seek to uncover what masculine indicators are demonstrated to both reify masculinity in the users of the apps and also in their desired partners. We first review previous scholarship of hegemonic masculinity, inclusive masculinity, gay masculinities, and gay app culture, followed by a textual analysis of profile content found on Scruff, Hornet, GROWLr, and GuySpy. The goal of this study is to not only contribute to networked masculinities and digital media research, but to also introduce a new process we have termed "mascing," which incorporates both hegemonic and inclusive masculinity.

\section{Literature Review}

\section{Hegemonic Masculinity}

Hegemonic masculinity has been criticized for relying on an essentialist underlying construction of masculinity that reduces masculinity to a homogenous set of traits or roles (MacInnes, 1998). This criticism is, perhaps, a more accurate examination of the reductionistic application of hegemonic masculinity in some scholarly research rather than an accurate 
criticism of the theory. Connell (2005) does, in fact, address this criticism stating, "Masculinity is not a fixed entity embedded in the body or personality traits of individuals. Masculinities are configurations of practice that are accomplished in social action and, therefore, can differ according to the gender relations in a particular social setting" (p. 122). The social norms associated with hegemonic masculinity provide meaning about the appropriate patterns of masculine performance, which are then internalized and negotiated in each person's construction of their gender identity (Connell, 1996). The appropriate patterns of performance are not predetermined and the "cultural template" of desirable masculinity is consistently reconfigured in a way that can appear to convolute notions of gender difference without discrediting the structure of patriarchy (Connell, 1996).

Scholars commonly tie hegemonic masculinity and the social power associated with hierarchical structures of gender to the realm of heterosexual men. Homosexual men are conceptualized as a "subordinate" category of men and are therefore excluded in scholarly considerations from the social benefits that occur as a result of compliant gender performance. Indeed, Demetriou (2001) argues for an examination of "internal hegemony" whereby homophobia manifests as a tool through which men police other men. A socially and historically contextual examination of masculine power does, of course, reveal the structural and social inequalities that have oppressed homosexual men. However, an argument can be made that the years of scholarship distinguishing sexuality from gender provide grounds for considering the way gay men are positioned to negotiate their gender identity and sexual identity through discursive practices that are constructed within the patterns of normative masculine performance that dictate social power. If, in fact, a collective understanding of normative symbols of masculinity exists and are tied to social power, it is beneficial to understand how homosexual men both resist and comply with these normative symbols.

Hegemonic masculinity, in the context of this paper, is not used as a base of comparison to analyze the degree to which gay men adhere to a set of homogenous masculine traits. Instead, this study examines the practical relationships between gay men and collective images of ideal masculine patterns of performance to better understand the way gay men resist, 
comply, and make sense of these patterns. This is particularly relevant in a networked environment that already assumes a relationship between masculinity and technology (Light, 2013). Presentations of self in a networked environment are restricted to the boundaries of the technological structure and, as such, this structure provides an interesting framework for the analysis gay men's practices of compliance and resistance.

\section{Inclusive Masculinity}

Policing of male groups can manifest as homophobia - "the fear that other men will unmask us, emasculate us, reveal to us and the world that we do not measure up, that we are not real men" (Kimmel, 2004, p. 88). It is homophobia that Anderson (2015) contends makes Connell's (1995) notion of hegemonic masculinity appropriate for understanding the "social organization of stratified masculinities" (p. 364). It is also levels of homophobia that provide the center of inclusive masculinity. The theory maintains that when cultural homophobia is high, and is coupled with the knowledge that homosexuality is present in one's culture, heterosexual males will vehemently establish that they are not gay. As homophobia declines, so does the stigma attached to homosexuality, permitting heterosexual males to engage in a wider range of behavior without the derision of being labeled gay.

While there may indeed be a decline in homohysteria in some regions of the world (Anderson, 2009; McCormack \& Anderson, 2010), the empiricism of inclusive masculinity studies have been restricted to Western countries like the U.S. and the U.K. and may not be applicable to other global regions (Rodriguez, 2016). In fact, we argue that even within the United States itself, there are areas where the levels of homophobia may fluctuate, but cultural norms and gender roles shape masculine behavior. The utility of inclusive masculinity lies in its attention to investigate localized lived experiences, dependent on temporal and spatial factors (Anderson, 2015). These localized experiences, however, do not operate in a vacuum and are still affected by hegemony. 


\section{MCS - Masculinities and Social Change, 5(3) 247}

\section{Gay Masculinity}

The regulation of "other" males by the elite masculine group is perhaps most prominently observed between heterosexual and homosexual, or effeminate male populations. However, we argue that it is also visible within gay populations. Aggressive masculinity is often exaggerated in an attempt to perform a type of masculinity that protects against threats of emasculation. Sexuality is "always grounded in wider material and social forces" and cannot be disconnected from "economic, religious, political, familial, and social conditions" (Plummer, 2005, p. 16). Masculine norms among gay men (and heterosexual men) are often formed during childhood and adolescence, long before they come out of the closet, alongside the aforementioned factors. Therefore, it is only reasonable that hegemony influences both heterosexual and homosexual men in their early, formative years. The policing of this masculinity then continues into adulthood.

The policing among male groups demonstrates Connell's (2005) claim that hegemonic masculinity is not restricted to power relations between genders but also explores power relations within genders (Demetriou, 2001, Ward, 2008). Within the hegemonic masculine lens, gay men are not excluded for their sexuality alone, but for the fact that their sexuality does not contribute to the patriarchal order (Demetriou, 2001). Labeled as internal hegemony, this maintains that hegemonic masculinity may actually be a "hybrid bloc that unites practices from diverse masculinities in order to ensure the reproduction of patriarchy" (p. 337). Although both Connell and Demetriou classify this internal hegemony as typically referring to heterosexual men's ascendancy over gay men, we argue that this social domination is also evident amongst gay men. Gay men are considered less masculine because they subsist outside the boundaries of heterosexuality and take other males as sexual partners. Consequently, gay men may feel societal pressure to shape and maintain their masculinity in recompense for their sexuality (Chesebro, 2001) and absence of power and status (Scott, 2011). There is an evident separation between gay men who display high levels of masculinity and those who display low levels of masculinity (Clarkson, 2006; Eguchi, 2009).

Gay men who identify as a "very straight acting male" use the label of "straight acting" as a means of gender identification (Connell, 1992). The 
labels "fem" and "sissy" are ascribed to effeminate gay men by more masculine males (Christian, 2005). These labels serve as semantic examples of how gay males both assert their masculinity and emasculate others to reify the power structure of hegemonic masculinity, thus creating a hierarchy of masculinities. Furthermore, gay males may enact hyper masculine manners and behaviors according to the current standards of hegemonic masculinity in order to reject the stereotypical archetypes of a gay man (Kimmel \& Mahalik, 2005; Messner, 1997).

Hegemonic masculinity can be looked at as a cultural ideal that is frequently encouraged by society through media portrayals of model masculinities (Demetriou, 2001). Huemmer's (2016) analysis of the film Superbad illustrates that even when the media place less emphasis on the heterosexuality of the masculine ideal, the patriarchal order remains intact. Examples of these exemplar masculinities in gay males have been found in print, television, online, and mobile media (Benzie, 2000; Payne, 2007, Avila-Saavedra, 2009; Chi, 2015). Researching masculinities within the institutions in which they are embedded positions scholarship to consider power structures on a global scale (Connell, 2012), something that inclusive masculinity neglects. We contend that hegemonic masculinity is a macrolevel process that informs micro-level processes of inclusive masculinity.

Because gay males are not bounded by the requirements found in the sexual system of masculinities, there is a possibility for the construction of many different homosexual manifestations of masculinities (Fejes, 2000). Particularly of interest is the use of digital media as a site of construction and maintenance. The current study examines how networked masculinities manifest in the digital spaces of gay dating apps. Networked masculinities are "those masculinities (co)produced and reproduced in conjunction with digitally mediated networked publics and their associated properties (Light, 2013).

\section{Gay Apps}

Social networking sites (SNS) provide a way to deconstruct and understand masculinities within heteronormative digital media (Harvey, 2015; Siibak, 2010). Light (2013) argues that SNS also provide a space to interrogate "non-normative, queer masculinities and relations" (p. 254). One such 
subgroup of SNS, geosocial networking apps (GSNs), enables users to find others in close proximity with one another. GROWLr, Scruff, Hornet, and GuySpy are GSNs that target males who might identify as gay, bisexual, or curious. Previous studies have investigated how these apps are used to find potential partners and are motivated by the user's desire to communicate, form relationships, or simply hook-up sexually (Gudelunas, 2012; Roth, 2015); or to investigate HIV and STI prevention health campaigns (Holloway, et al., 2010; Wilkerson, Smolenski, Morgan, \& Simon Rosser, 2012). We will refer to these apps as "gay dating apps."

Gay dating apps are fitting spaces to investigate the nuances of communication between gay males. Users are able to create profiles that convey their identity, intentions, and requirements of potential partners, and because of their interconnectedness, these apps are spaces for various sexualities and masculinities. Furthermore, the geographic focus of these apps transcends the boundaries of virtual spaces and real-world (Bumgarner, 2013). Gay dating apps can only be accessed via mobile phone, expanding the social opportunities of users by visibly revealing other users nearby (Blackwell \& Birnholtz, 2014). Of scholarly importance is the way in which gay males utilize these apps to negotiate their masculinities amongst each other.

Recent studies have examined how hegemonic masculinity influences the creation of identity on gay dating apps (Reynolds, 2015; Roth, 2015). Within these studies pejorative terms served as discourse to create a power dichotomy, ultimately reinforcing hegemonic masculinity (Reynolds, 2015). Also, gay dating apps serve as a virtual space that intersects with offline geographic locations, which raise questions of influence and replacement for real-life social interaction (Roth, 2015). A majority of these studies primarily focus on one app and do not compare masculinity between gay dating apps. This study seeks to fill the gap in literature by comparing manifested networked masculinities in GROWLr, Scruff, Hornet, and GuySpy. We pose the following research questions:

RQ1: Do gay dating apps construct technological boundaries for the presentation of networked masculinities? 
RQ2: How are networked masculinities constructed within the bounded spaces of gay dating apps in regards to user's personal description?

RQ3: How are networked masculinities constructed within the bounded spaces of gay dating apps in regards to user's desired partners?

\section{Method}

This study employed a textual analysis of gay dating app user profile content. A textual analysis provides us with the more in-depth and nuanced observations of a qualitative approach (Leech, Dellinger, Brannagan, \& Tanaka, 2010). Our unit of measurement was individual user profiles in gay dating apps, specifically Scruff, GROWLr, GuySpy and Hornet.

\section{Sampling}

Our sampling frame follows Riffe, Lacy, and Fico's (2014) online sampling guidelines. Since apps, like online content, are interactive, immediate, multimodal, and include hyperlinks, the first stage is to perform multiple, detailed searches to accumulate a list of possible samples. Once searches were conducted through the app store and in search engines, we compiled our list of the top apps that met the necessary criteria of displaying users' profiles and extensive geographic location searches. We then took a rank list of top gay dating apps (Rukkle, 2014) and selected the first four apps that met the study's inclusive criteria: being able to search specific zip codes from a remote location. Grindr is listed as the most used app amongst gay males, however it does not allow a user to enter exact zip codes, nor does it allow for a global subgroup of users. Users are limited to search profiles of men that are in close proximity to the user. Therefore, we did not include Grindr in our analysis and utilized the other apps that rounded out the top five: Scruff, Hornet, GROWLr, and GuySpy.

Hornet and GuySpy position themselves to target a broader, more general audience. There is no definite delineation for the typical user and 
both apps boast access to "the hottest guys" for not only gay males, but also males who consider themselves bi or curious. Conversely, Scruff and GROWLr both tend to attract "bears" and "jocks" (Rukkle, 2014). The users of these apps are typically hairy, muscular men and are, therefore, more indicative of a presentation of self that aligns with the current cultural template of hegemonic masculinity. Scruff and GROWLr also attract those who desire bears and jocks.

A random list of 20 zip codes was then generated, each app being assigned five unique zip codes. The first 25 profiles with a picture included in the profile were then coded per assigned zip code for a total of 500 user profiles in the sample $(N=500)$. This sample was used for both the qualitative and the quantitative analysis of our study. Inductive thematic coding was performed on the personal narratives found in each user's profile.

\section{Results}

\section{Technological Structures and Networked Masculinities}

In regards to RQ1, Do gay dating apps construct technological boundaries for the presentation of networked masculinities, we found that each app required certain identifying information and that this information was usually restricted to a set of options provided by the app (see Table 1). The apps also provided optional identity information categories that included written descriptions and restricted category selections, and options to ignore or exclude other users based on various identity descriptions.

Previous scholars have identified the various ways that technology is gendered in particularly masculine ways (Light, 2013). It is necessary then to define the ways technology itself imposes a structured framework for presenting identity to better understand how gay men negotiate presentations of self within these structures. The four apps all required the user to agree to the terms of service, agree or disagree to enable location access, and agree or disagree to allow the app to send the user notifications. Once the user completes these initial steps, he is allowed to create a user profile. Each app shared similar baseline profile requirements including an email, password, and username. Guyspy differed the most markedly from 
the other apps in that it required the user to upload a picture in order to complete the profile creation process.

Table 1

Percentages of Preset Descriptive Options in Gay Dating Apps

\begin{tabular}{lcc}
\hline \multicolumn{1}{c}{ Characteristic } & Self & Potential Partners \\
\hline Personal & & \\
\hline Bear, Polar Bear & 14.8 & 21.0 \\
College, Geeks & 10.4 & 12.2 \\
Muscle, Big Muscle, Jock & 9.2 & 27.2 \\
Cub, Boy & 6.8 & 11.8 \\
Daddy, Silver Daddy, Sugar & 6.6 & 15.2 \\
Daddy & & \\
Chaser, Daddy Chaser, Bear & 6.6 & 10.0 \\
Chaser & & \\
Discreet & 6.0 & 5.0 \\
Twink & 3.0 & 5.6 \\
Chub, Super Chub & 3.6 & 6.2 \\
Leather & 3.4 & 6.2 \\
Transgender, Transsexual & 0.2 & 1.2 \\
Bi-curious, Bisexual & 0 & 0 \\
\hline Other & 10 & .4 \\
\hline Positon & & \\
Versatile & 18.0 & 14.0 \\
Bottom & 7.2 & 5.0 \\
Top & 6.2 & 7.0 \\
\hline Note. $(N$ = 500) Each app (Scruff, GROWLr, GuySpy, and Hornet) had \\
preselected options to describe "user" and "looking for." Categories were \\
not mutually exclusive. & & \\
&
\end{tabular}

Aside from the required basic profile descriptors, each app allowed various optional identity and preference indicators. Optional identity descriptors generally included weight, height, age, and ethnicity. In all four categories, the user was forced to select a descriptor from the option choices listed. Restricting identity choices to a set of specified options in 
categories like age, weight, height, and even ethnicity may not seem unusual or particularly restrictive. However, the apps similarly restricted the more nuanced and complex categories of sexual preference, sexual identity, and relationship status to a limited set of options. For example, each app allowed the user to describe their sex role identity by selecting descriptive terms like bear, twink, geek, leather, etc. Some apps also allowed users to construct their sexual identity through more overt sex role identity descriptions like top, bottom, and versatile. The apps also allowed users to indicate the sex role identities that they desired in a partner along with the type of relationship they were seeking (i.e. friendship, husband, love, etc.). These descriptions were also limited to the selections presented on the app. While each app allowed the users to write a description of themselves in their own words, typically in an 'about me' section, these descriptions were often limited by the specific number of text characters the app allowed.

The overt restrictions placed on self-presentation by the technological framework of the app are most obviously experienced through the process of creating a user profile. A more subversive element of presenting and controlling identity presentation was, however, found in the account settings where users were given the option to limit who was allowed to view their profile or filter the types of profiles they were shown on the app. These filters and control options were frequently based on identity indicators like weight, age, and ethnicity so that users who identified as a certain ethnicity or age were immediately filtered out of the user's experience with the app.

These technological structures are not neutral, nor are they unique to the gay dating community. The emphasis placed on sex roles, age, and ethnicity, the utility and function of the profiles and descriptive categories, and the boundaries placed on the options used to describe complex gender and sex identities are created in and informed by overarching ideologies. Thus, the description of the app structure itself informs our analysis of the way gay men create profiles that resist and comply with more macro ideologies about gender, specifically hegemonic masculinity. 


\section{Instances of Networked Masculinities in Self}

In regards to RQ2, how are networked masculinities constructed within the bounded spaces of gay dating apps in regards to user's personal description, we found themes that primarily centered on masculinity and body. Perhaps the most prevalent example of compliance with hegemonic masculinity manifested in these networked masculinities was the blatant, unrestrained use of the word masculinity itself. Statements such as "I'm a chill masc bottom boi looking for fwb ..." (NJBottomBoi), "vers here/mostly top and masculine" (Khen_9), and "LatinoM4M / Masc Chicano Top Looking for Bottom/Vers Latino Uncut Mix Race..." (Rafa) demonstrate how the users view themselves as masculine. Furthermore, the self-imposed label of "masculine" was consistently used as a discursive symbol of gender identity that held, on some level, a meaning that was collectively understood and therefore did not require further explanation. This pattern of presentation is then interpreted as a performance of masculinity that is complicit with the definition of masculinity that has been constructed through hegemonic masculinity. Again, if sexual identity is understood as separate from gender identity, it becomes easier to see how discursive patterns of masculine identity construction among men using gay dating apps are informed by similar patterns in both the heterosexual and homosexual dating communities.

Connell (1996) argues that the body is the most literal tool for "doing" gender as a pattern of actions. The users' profiles supported this argument through the repeated emphasis placed on the body and its sexual and athletic functions. The specific focus on the sexual and athletic actions of the body provided interesting points of analysis in that critical scholarship has identified these two themes as imperative in the negotiations of heterosexual masculine hierarchies (Connell, 2005; Kimmel, 2004). The role of the body as a tool for negotiating masculine hierarchies appeared to inform a similar hierarchical structure within the users' profiles and was presented through references to gym use and athletic prowess. This assertion of an embodied masculinity is consistent with Connell's (2005) claim that sports and competition are used to establish a man's "right to rule" within the masculine hierarchy. One user stated, "I'm an athletic guy soccer, wrestling, lifting \& running. Love going on adventures with my 
dog, kayaking, paddle boarding" (Coach). Studies have demonstrated that the most typical masculine archetypes are jocks (Scott, 2011). Thus, the entire concept of a "jock" embodies an athletic ethos of physique, attire, and sportsmanship.

The users' profiles also constructed the penis as a discursive symbol of male power, again situating the body as an important site of meaning in the construction of masculinity in these networked environments. The penis is not only a visually obvious reference to manhood and masculinity, but also a value-laden reference to masculine power and dominance in the most primal and historical sense (Kimmel, 2004). One user described himself as, "good looking well-endowed" (smokeethree). Similarly, a recent online survey indicated that $83 \%$ of gay men have sent a "dick pic" on a gay dating app (Alvear, 2015). The body, and specifically the penis, is still identified as a site where the symbolic meanings of masculinity are 'done' regardless of homosexual or heterosexual orientations of the sex act.

\section{Instances of Networked Masculinities in Desired Partners}

In regards to RQ3, how are networked masculinities constructed within the bounded spaces of gay dating apps in regards to user's desired partners, the pattern of using the word 'masculine' as a heuristic for indicating a shared understanding of the traits associated with an ideal gender presentation was again visible in the users' profile descriptions of ideal traits in desired partners. Within the profile sections that restricted sections of 'what I'm looking for' to a list of option choices presented by the app, there was a greater variance in the users' selection of various descriptive traits of a desired partner (i.e. leather, twink, masculine, geek, etc.). However, when profile users were presented with the option to write "what I'm looking for" in their own words, the word 'masculine' was reiterated as the most salient and ideal trait in a desired partner. "NSA fun. Top looking for masculine" (Tony) and "Looking for a masculine man" (smoothtwink) demonstrate the straightforward request from users for their prospective partner to embody traits of masculinity that represent the commonly held ideas of appropriate gender performance. This interpretation is particularly supported when users apply other stereotypically "masculine" adjectives in conjunction with their use of the word "masculine." For example, "Looking for Muscular, 
Masculine guy!!" (dopekid234), "I'm into masculine, beefy, fury, funny, accepting and understanding guys" (DougMat32), and "I prefer my guys masculine like myself, preferably athletic." Here the users clearly associate masculinity with specific traits. Again, the users never define what masculine is which supports the idea that the meanings associated with the use of the word 'masculine' as a descriptor of oneself and one's desired partner, do not differ from the collective meanings of masculinity that exist outside of the homosexual dating community and, therefore, require no further elaboration.

While the users' profiles negotiated meanings of the male body as a subject that 'does' masculinity in the sections of the app that allowed for self-description, the profiles also negotiated the male body as an object that receives desire and evaluation. One fundamental attribute of masculinity, as discussed above, is the idyllic image of a muscular, fit body. This was also conveyed in the discourse about desired partners. Statements such as "looking for a good looking, muscular/fit guy" (Bahamut) and "occasional NSA fun with sexy, confident guys who take care of their bodies" (stu) are testaments to the request of fit bodies. A leaner, muscular, more athletic physique is equivalent to masculinity in gay males (Tiggemann, Martins, \& Kirkbride, 2007). It could also be interpreted as a more salient signal of health in the gay community against the backdrop of HIV (Levesque \& Vichesky, 2006)

Equally, any male body which is not fit is considered less than desirable. Users who had masculine substandard bodies acknowledged their deficiency through statements such as, "I don't have a gym bod but I'm working on it" (howdy+) and "looking around for someone...that is nice and doesn't mind chubby guys like myself" (justme_ky). Straightforward self-descriptions like these weed out those users who are simply looking for an ideal body type. Furthermore, some users emphasized personal and sexual characteristics in lieu of their subpar bodies: "very oral here... get to know me, real nice guy here, bf material. I may not have 6pk abs like most stuck ups on here but I have lots to offer (dates?)" and "I'm not idealistic, so not lookin for love, just fun" (Joe). These users offered personality and sexual favors in recompense for their less than masculine body types.

Sustaining hegemonic masculinity embraces the rejection and degradation of subordinate masculinities (Kimmel, 2003). There was a clear 
theme of dominate top versus submissive bottom. Statements such as "Looking for a sub bottom that stimulates both my heads" (Osofeeder) and "Sub BTTM for DOM aggressive tops. Total sub man here!!! Zero gag reflex...can go all night" (hitsithard) illustrate this dichotomy. Traditionally, males who are the penetrating partner during sex are viewed as more masculine, whereas the male who is penetrated is seen as less masculine (Potoczniak, 2007). By identifying as a dominate top in search of a submissive bottom, the user not only reifies his masculinity, but also reinforces a dichotomy of power (Connell \& Messerchmidt, 2005; Demetriou, 2001). By identifying as a submissive bottom, the user indicates that a more dominate, masculine male is more desirable.

There was also the expression of wanting facial and body hair in desired partners. Statements such as "*Beards and hairy chests*" (blknthecity), "Beards, assertiveness, hairy chests and fun loving attitude" (JB), and "Love beards, furry chests, and ass worshippers" (Specturm Ranger) serve as examples. Beards have long been important factors in perceived heterosexual masculinity, however it wasn't until the last 20 years that body hair became a symbol of homosexual masculinity (Hennen, 2005). Body hair is indicative of a "bear subculture" that seeks to assert a homosexual masculinity that rejects body fascism and embraces a more natural look (Lucie-Smith, 1991). Body hair has since been both accepted and expected as part of a raw masculinity (Suresha, 2002).

Within the negotiations of traditional masculine hierarchies in the U.S., racial categories are used to establish white masculinity as illustrative of the cultural template of ideal manhood thus subordinating all other racial identities (Connell, 1992). The importance of race as an indicator of desirability and exclusivity was, indeed, assumed in the very structure of the apps which allowed users to block members of other racial categories. A parallel manifestation of racial preference was also uncovered in sections of the user's profiles that allowed the user to describe preferences in their own words. Statements such as "typically prefer white guys" (Tanner) and "Safe fun with young fit guys prefer white guys but not opposed to others" (Benno) coincide with those of other scholars who found that gay culture is not only gendered, but also can be particularly racialized (Ocampo, 2012; Ward, 2008). 


\section{Gay Divergence form the Cultural Masculine Template}

The gay dating community is, however, distinct in many important aspects from other male community groups. Connell and Messerschmidt's (2005) argument that research should begin to localize manifestations of masculinity within specific communities sheds light on the specific contributions of Anderson's inclusive masculinity theory in the context of the networked gay dating community. Anderson argues that as homohysteria declines, stereotypical performances of masculinity become unnecessary. This idea is particularly applicable in the context of a gay dating community where, presumably, instances of homophobia are limited. It becomes important then to understand how the relevant issues and identity presentations that are specific to the gay community manifest in a way that negotiates resistance to the normative patterns of masculine performance. The abovementioned findings along with the more traditional research about normative masculinity point to sexual orientation as the most readily identifiable point of divergence from the cultural template of ideal masculinity. Not everyone who uses gay dating apps identifies as gay and, as such, the negotiations for managing the potentially stigmatizing identity of 'gay' were particularly relevant to this specific technological space.

The users' profiles revealed that words like 'discreet' and 'down-low' were used as both descriptions of the self and descriptions of desirable traits in potential partners. Py writes on his profile "Masculine, fit, discreet...Looking for similar," while devmichae195 writes "Looking for some DL fun. Discreet, laid back." Both users demonstrate the reluctance to disclose their identity, possibly for fear of being labeled as gay (King \& Hunter, 2004). Anonymity has been found to be a specific gratification amongst gay app users (Gudelunas, 2012). Partners are chosen based on how well they will help conceal one's sexual identity from the rest of society (McCune, 2014). This discourse illustrates the significance of networked spaces as sites that allow for a presentation of the self that may conflict with 'everyday' presentations. It further illustrates that, within these spaces, app users can participate in sexual behaviors that may deviate from what they feel is a culturally acceptable 'masculine' behavior while still maintaining a gendered identity that mirrors the cultural standard of 'masculine' in other significant ways. 
Another issue that appears more salient among the gay dating community is the health risk associated with using gay dating apps for anonymous sex (Holloway et al., 2013). The option to disclose HIV status was therefore an element built into the structure of some of these gay dating apps and was frequently considered a relevant identity description among users. For some men, communicating details about HIV status upfront may eliminate the need to discuss such issues in person (Sheon \& Crosby, 2004). "Bottom here. I'm HIV neg and disease free and I play safe only" (sam) and "Into barebacking, negative but on PREP" (JLo69) indicate that not only are these users aware of their status, but they also want to prevent any health risk associated with hooking up. While other users do not disclose their HIV status, they still communicate their intentions of having safe sex in upfront manners, "If you want bareback sex, I'm not your man" (mark). This quote serves as an example of the social stigma and judgment against those with HIV in the gay community. In a recent online study, two thirds of respondents who identified as HIV-negative say they are not likely to initiate contact with or respond to an attractive guy who states he is HIVpositive in his profile (Alvear, 2015).

Unlike the above statements where users were forthright with their status, this type of discourse can lead to increased silence and hesitancy of disclosing one's status (Haig, 2006). As previously stated, the body is an important tool for constructing meanings of masculinity, as such, the open and forthcoming discourse about the HIV status of one's body resists many of the socially constructed notions of deviance that have historically been assigned to men who do not adhere to ideas that heterosexuality is a necessary component of masculinity. The gay dating app users' processes of constructing patterns of masculinity within a networked environment include instances of compliance with cultural norms, but also instances of resistance that are unique to the community but no less valid in informing the complex facets of masculine identity.

\section{Conclusion}

Throughout history there have been overarching systems of regulations and boundaries for heterosexual masculinity, however there is none for homosexuals. There is "no normal way to be gay that is enforced through 
law, medical, and psychological knowledge, and custom and socialization" (Fejes, 2000). Thus, how do gay males come to define their masculinity, and ultimately themselves? While the latter is beyond the scope of this study, we do find evidence in our results to offer enlightenment on how gay males define masculinity on digital spaces, specifically in user profiles on gay dating apps. Masculinities range on a continuum from extreme to moderate to deficient. These masculinities are socially inspired and guided by the temporal and spatial limitations of geography, culture, and communication platform.

To understand this range of networked masculinities we employed a textual analysis of gay dating app profiles. Users communicated their desired qualities in potential partners and to showcase their own masculinities. These masculinities are influenced by technological restrictions within the app: the pre-conceived categories produced by the app creators. However, the users were permitted to freely write within the "about me" section. Both the pre-conceived categories and the open-ended "about me" sections were utilized to investigate networked masculinities. The manifestations of networked masculinities found primarily centered on companionship, sex, sexuality, and the dichotomy of power to reinforce masculine hierarchies. This process, that we have termed "mascing," is a way for gay males to reinforce their own masculinity, while also maintaining masculine norms by seeking out masculine partners. Mascing is a form of policing that reinforces a masculine elite within the gay dating app community, an elite that is predominately white, young, fit, and healthy.

The networked masculinities found among gay males using these apps were similar to those outlined in Connell's (1995) conception of hegemonic masculinity. We argue that hegemony in a larger social structure influences masculine norms, norms that are found in both heterosexual and homosexual men. Anderson's (2009) concept of inclusive masculinity is also questioned. The theory maintains that as homophobia declines, so does the stigma attached to homosexuality, permitting heterosexual males to engage in a wider range of behavior without the derision of being labeled gay. The digital space of gay dating apps is free of homophobia and is exclusive to users who engage in sex with other men, yet we still see the policing of masculinity. The digital space provides for a more broad display 
of behaviors and the users still predominately prefer to engage in hegemonic tendencies. The networked masculinities reified in gay dating apps are more influenced by hegemony than they are by levels of homophobia.

This study, like others, is not without limitations. First, because we wanted to conduct a random sample of various geographic locations within the U.S., we were limited to apps that allowed for wider geographic searches. Due to this technological restraint, none of the apps selected rank as the number one poplar user app, instead we reconciled on the next highest ranked apps, all of which are still very popular and provide a diverse selection of gay males. Secondly, due to qualitative approach we were limited in sample size, because too large of a sample would make qualitative study impractical. We did not want to sacrifice the complex and in-depth richness that qualitative research provides. We feel our approach combines the benefits of qualitative inquiry and nation-wide sampling which helps balance out respective weaknesses.

Future directions in research on gay masculinities in gay dating apps might also address the profiles of those users who do not identity within the archetypes of the straight-acting gay male. There is important consideration to be taken of those individuals who fall outside the boundaries of heteronormative criterions and the reasons why, and how, they utilize mobile platforms. We understand that gay males are not one monolithic, hegemonic group, but instead diverse and idiosyncratic. The multiplicity of sexualities, masculinities, and ideologies warrant a more nuanced and indepth understanding of how this faction of society interacts and communicates amongst each other.

Secondly, by conceptualizing our findings as a process, mascing, we leave open the opportunity to situate the process itself into a greater theoretical orientation. Future research should employ qualitative initiatives to better understand the framework of networked masculinities in the realm of gay digital media and social networking sites. Connell (2012) challenges scholars to apply hegemonic masculinity to the examination of social structures and institutions. This application allows for a more holistic examination of the various interconnected social systems that construct hegemonic masculinity both locally and collectively, while considering structural, liminal, and localized masculine norms 
Compared to the past when the coming out process for gay males included recognizing and accepting repressed sexual desires, today's process is more about the consumption and creation of acceptable gay masculinities (Fejes, 2000). We have moved beyond the between-group comparisons among hetero- and homosexual men, and moved into a more within-group comparisons of males. Gay males have created niche subdivisions and are hastily moving in different directions.

While a majority of our findings point toward the hypermasculine user searching for other masculine males for anonymous hookups, there is utility in apps as constructive relationship tools. To make a normative statement that all gay dating apps are hook up apps takes away from the nuanced and diverse function of the apps. These assorted functions, when combined with the variety of users, helps create a social environment that is constantly changing and evolving based on social interaction and external factors; thus, influencing the negotiation of various networked masculinities by gay males.

\section{References}

Anderson, E. (2009). Inclusive masculinity: The changing nature of masculinities. New York, NY: Routledge.

Anderson, E. (2015). Assessing the sociology of sport: On changing masculinities and homophobia. International Review for the Sociology of Sport, 50(4-5), 363-367. doi:10.1177/1012690214538628

Alvear, M. (2015, March 18). 83 percent of gay men have sent a dick pic on dating apps, says survey. Huffington Post. Retrieved from http://www.huffingtonpost.com/mike-alvear/83-percent-of-gay-mensend-dick-pics-on-dating-apps-says-survey_b_6893316.html

Avila-Saavedra, G. (2009). Nothing queer about queer television: Televized construction of gay masculinities. Media, Culture, and Society, 31(1), 5-21. doi:10.1177/0163443708098243

Benzie, T. (2000). Judy Garland at the gym — gay magazines and gay bodybuilding. Continuum: Journal of Media \& Cultural Studies, 14(2), 159-170. doi: 10.1080/713657700 
Blackwell, C., Birnholtz, J., \& Abbott, C. (2014). Seeing and being seen: Co-situation and impression formation using Grindr, a locationaware gay dating app. New Media \& Society, 1-20. doi:10.1177/1461444814521595

Bumgarner, B. (2013) Mobilizing the gay bar: Grindr and the layering of spatial context. In Conference of the International Communication Association, London, UK.

Chesebro, J. W. (2001). Gender, masculinities, identities, and interpersonal relationship systems: Men in general and gay men in particular. In L. P. Arliss \& D. J. Borisoff (Eds.), Women and men communicating: Challenges and changes (pp. 33-64). Long Grove, IL: Wavel and Press.

Chi, K. R. (2015). Masculinity: Men's makeover. Nature, 526(7572), S12S13. doi:10.1038/526S12a

Christian, T. Y. (2005). "Good cake" An ethnographic trilogy of life satisfaction among gay black men. Men and Masculinities, 8(2), 164174. doi:10.1177/1097184X04271358

Clarkson, J. (2006). "Everyday joe" versus "pissy, bitchy, queens": Gay masculinity on straightacting.com. The Journal of Men's Studies, 14(2), 191-207. doi:10.3149/jms.1402.191

Connell, R. W. (1992). A very straight gay: Masculinity, homosexual experience, and the dynamics of gender. American Sociological Review, 57(6), 735-751. Retrieved from http://www.jstor.org/stable/2096120

Connell, R. W. (1995). Masculinities: Knowledge, power and social change. Berkeley, CA: University of California Press.

Connell, R. W. (1996). Teaching the boys: New research on masculinity, and gender strategies for schools. The Teachers College Record, 98(2), 206-235. Retrieved from http://www.tcrecord.org/content.asp?contentid=9614

Connell, R. (2012). Masculinity research and global change. Masculinities \& Social Change, 1(1), 4-18. doi:10.4471/MCS.2012.01

Connell, R. W., \& Messerschmidt, J. W. (2005). Hegemonic masculinity rethinking the concept. Gender \& Society, 19(6), 829-859. doi:10.1177/0891243205278639 
Demetriou, D. Z. (2001). Connell's concept of hegemonic masculinity: A critique. Theory and Society, 30(3), 337-361.

doi:10.1023/A:1017596718715

Eguchi, S. (2009). Negotiating hegemonic masculinity: The rhetorical strategy of "straight-acting" among gay men. Journal of Intercultural Communication Research, 38(3), 193-209.

doi:10.1080/17475759.2009.508892

Fejes, F. (2000). "Making a gay masculinity". Critical Studies in Media Communication, 17(1), 113-116. doi:10.1080/15295030009388382

Freeman, C. (2014, October 16). Hook-up apps are destroying gay youth culture. Time. Retrieved from http://time.com/3510261/hook-upapps-destroying-gay-relationships/

Gudelunas, D. (2012). There's an app for that: The uses and gratifications of online social networks for gay men. Sexuality \& Culture, 16(4), 347-365. doi:10.1007/s12119-012-9127-4

Harvey, L., \& Ringrose, J. (2015). Sexting, ratings and (Mis) Recognition: Teen boys performing classed and racialized masculinities in digitally networked publics. In E. Renold, J. Ringrose, \& R. D. Egan (Eds), Children, Sexuality and Sexualization (pp. 352-367). New York, NY: Palgrave Macmillan.

Hennen, P. (2005). Bear bodies, bear masculinity recuperation, resistance, or retreat? Gender \& Society, 19(1), 25-43. doi:10.1177/0891243204269408

Huemmer, J. (2016). Beyond boobs and beer: Analysis of masculine rites of passage in the film Superbad. Southwest Mass Communication Journal, 31(2). Retrieved from http://swecjmc.wp.txstate.edu/files/2016/05/huemmer.pdf

Kimmel, M. (2003). Masculinity as homophobia. In M. S. Kimmel \& A. L. Ferber (Eds.), Privilege: A reader (pp. 51-74). Boulder, CO: Westview Press.

Kimmel, M. (2004). Masculinity as homophobia. In Rothenberg, P. S. (Ed.), Race, class, and gender in the United States: An integrated study. (81-92). New York, NY: Macmillan.

Kimmel, S. B., \& Mahalik, J. R. (2005). Body image concerns of gay men: The roles of minority stress and conformity to masculine norms. 
Journal of Consulting and Clinical Psychology, 73(6), 1185-1190. doi:10.1037/0022-006X.73.6.1185

King, J. L., \& Hunter, K. (2004). On the down low: A journey into the lives of" straight" Black men who sleep with men. New York, NY: Harlem Moon.

Leech, N. L., Dellinger, A. B., Brannagan, K. B., \& Tanaka, H. (2010). Evaluating mixed research studies: A mixed methods approach. Journal of Mixed Methods Research, 4(1), 17-31. doi:10.1177/1558689809345262

Levesque, M. J., \& Vichesky, D. R. (2006). Raising the bar on the body beautiful: An analysis of the body image concerns of homosexual men. Body image, 3(1), 45-55. doi:10.1016/j.bodyim.2005.10.007

Light, B. (2013). Networked masculinities and social networking sites: A call for the analysis of men and contemporary digital media. Masculinities \& Social Change, 2(3), 245-265. doi:10.4471/mes.2013.34

Lucie-Smith, E. (1991). The cult of the bear. In C. Nelson (Ed.), The bear cult (pp. 6-8). London, UK: Gay Men's Press.

MacInnes, J. (1998). End of masculinity: The confusion of sexual genesis and sexual difference in modern society. Buckingham, UK: McGrawHill Education.

McCormack, M., \& Anderson, E. (2010). 'It's just not acceptable any more': The erosion of homophobia and the softening of masculinity at an English sixth form. Sociology, 44(5), 843-859. doi:10.1177/0038038510375734

McCune Jr, J. Q. (2014). Sexual discretion: Black masculinity and the politics of passing. Chicago, IL: University of Chicago Press.

Messner, M. A. (1997). Politics of masculinities: Men in movements. Thousand Oaks, CA: Sage.

Ocampo, A. C. (2012). Making masculinity: Negotiations of gender presentation among Latino gay men. Latino Studies, 10(4), 448-472. doi:10.1057/1st.2012.37

Payne, R. (2007). Str8acting. Social Semiotics, 17(4), 525-538. doi:10.1080/10350330701637106

Plummer, K. (2007). Queers, bodies, and postmodern sexualities: A note on revisiting the "sexual" in symbolic interactionism. In M. Kimmel 
(Ed.), The sexual self: The construction of sexual scripts (16-30). Nashville, TN: Vanderbilt University Press.

Poole, J. (2014). Queer representations of gay males and masculinities in the media. Sexuality \& Culture, 18(2), 279-290. doi:10.1007/s12119013-9197-y

Potoczniak, D. J. (2007). Development of bisexual men's identities and relationships. In K. J. Bieschke, R. M. Perez, K. A. DeBord, K. J. Bieschke, R. M. Perez, K. A. DeBord (Eds.), Handbook of counseling and psychotherapy with lesbian, gay, bisexual, and transgender clients (2nd ed.) (pp. 119-145). Washington, DC: American Psychological Association. doi:10.1037/11482-005 Reynolds, C. (2015). "I am super straight and I prefer you be too":

Constructions of heterosexual masculinity in online personal ads for "straight" men seeking sex with men. Journal of Communication Inquiry, 39(3), 213-231. doi:10.1177/0196859915575736

Riffe, D., Lacy, S., \& Fico, F. (2014). Analyzing media messages: Using quantitative content analysis in research $\left(3^{\text {rd }} e d\right.$.). New York, New York: Routledge.

Rodriguez, N. S. (2016). \#FIFAputos: A Twitter textual analysis over "puto" at the 2014 World Cup. Communication \& Sport [ahead of print]. doi:10.1177/2167479516655429

Roth, Y. (2015). "No overly suggestive photos of any kind": Content management and the policing of self in gay digital communities. Communication, Culture \& Critique, 8(3), 414-432. doi:10.1111/cccr.12096

Rukkle. (2014). Best dating apps of 2014. Rukkle.com. Retrieved from http://rukkle.com/features/best-gay-dating-apps-2014/

Scott, D. T. (2011). Contested kicks: Sneakers and gay masculinity, 19642008. Communication and Critical/Cultural Studies, 8(2), 146-164. doi:10.1080/14791420.2011.566275

Sheon, N., \& Crosby, G. M. (2004). Ambivalent tales of HIV disclosure in San Francisco. Social Science \& Medicine, 58(11), 2105-2118. doi:10.1016/j.socscimed.2003.08.026

Siibak, A. (2010). Constructing masculinity on a social networking site: The case-study of visual self-presentations of young men on the 
profile images of SNS Rate. Young, 18(4), 403-425.

doi:10.1177/110330881001800403

Suresha, R. J. (2002). Bears on bears: Interviews and discussions. Los

Angeles, CA: Alyson Books.

Tiggemann, M., Martins, Y., \& Kirkbride, A. (2007). Oh to be lean and muscular: Body image ideals in gay and heterosexual men.

Psychology of Men \& Masculinity, 8(1), 15-24. doi:10.1037/15249220.8.1.15

Ward, J. (2008). Dude-sex: White masculinities and 'authentic' heterosexuality among dudes who have sex with dudes. Sexualities, 11(4), 414-434. doi:10.1177/1363460708091742

Wilkerson, J.M., Smolenski, D.J., Morgan, R., Simon Rosser, B.R. (2012).

Sexual agreement classifications for gay and bisexual men and implications for harm reduction HIV prevention. Health Education \& Behavior 39(3) 303-314. doi: 10.1177/1090198111413917

Jennifer Huemmer is Graduate Part-Time Instructor at Texas-Tech University, United States.

Lindsey E. Blumell is visting research fellow at Oxford Brookes University, United Kingdom.

Nathian Shae Rodriguez is lecturer at San Diego State University, United States.

Contact Address: Direct correspondence to Nathian Shae Rodriguez, School of Journalism and Media Studies, College of Professional Studies and Fine Arts, San Diego State University, 5500 Campanile Drive, San Diego, CA 92182-4561, email: nsrodriguez@sdsu.edu 


\section{Hipatia Press}

Instructions for authors, subscriptions and further details:

\section{The Five Stages of Masculinity: A New Model for Understanding Masculinities}

Joseph Gelfer ${ }^{1}$

1) University of Divinity, Australia

Date of publication: October $21^{\text {st }}, 2016$

Edition period: October 2016 - February 2017

To cite this article: Gelfer,J. (2016). The Five Stages of Masculinity: A New Model for Understanding Masculinities, Masculinities and Social Change,5(3),268-294. doi: 10.17583/MCS.2016.2169

To link this article: http://doi.org/10.17583/MCS.2016.2169

PLEASE SCROLL DOWN FOR ARTICLE

The terms and conditions of use are related to the Open Journal System and to Creative Commons Attribution License (CC-BY). 
pp. 268-294

\section{The Five Stages of Masculinity: A New Model for Understanding Masculinities}

Joseph Gelfer

University of Divinity, Australia

\section{Abstract}

The article uses the so-called "crisis of masculinity" as a jumping-off point for proposing a new model for understanding masculinities called the Five Stages of Masculinity. The five stages outlined in the article are: Stage 1, Unconscious Masculinity; Stage 2, Conscious Masculinity; Stage 3, Critical Masculinities; Stage 4, Multiple Masculinities; Stage 5, Beyond Masculinities. A content analysis of news and magazine articles is provided to give some initial indication as to the proportion of public conversations taking place at each stage. The article concludes by discussing the implications of the Five Stages of Masculinity for the study of men and masculinities, as well as some new thoughts on the nature of the crisis of masculinity via a mobilization of Giorgio Agamben's concept of the "state of exception."

Keywords: crisis of masculinity, stages of masculinities, content analysis 


\section{Los Cinco Estadios de la}

\section{Masculinidad: Un Modelo Nuevo para Entender las Masculinidades}

Joseph Gelfer

University of Divinity, Australia

\section{Resumen}

El artículo utiliza la llamada "crisis de la masculinidad" como punto de partida para proponer un nuevo modelo para la comprensión de las masculinidades, este nuevo modelo se concreta en cinco etapas. Las cinco etapas descritas en el artículo son: Etapa 1, masculinidad inconsciente; Etapa 2, masculinidad consciente; Etapa 3, masculinidades críticas; Etapa 4, masculinidades múltiples; Etapa 5, más allá de las masculinidades. De este modo, se proporciona un análisis de contenido de noticias y artículos de revistas para dar alguna indicación inicial como indicador de la proporción de conversaciones públicas que tienen lugar en cada etapa. El artículo concluye con un análisis de las implicaciones de las cinco etapas de la masculinidad para el estudio de los hombres y las masculinidades, así como algunas nuevas ideas sobre la naturaleza de la crisis de la masculinidad a través de una reformulación del concepto de Giorgio Agamben: "estado de excepción".

Palabras clave: crisis de la masculinidad, estadios de la masculinidad, análisis de contenido 



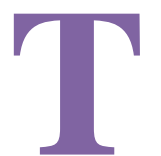

he idea that masculinity is "in crisis" has taken on a mantralike quality in both popular and academic domains. This discourse of crisis is aided by the fact that it can mean different things to different people, which results in constituencies with wholly different-and typically perceived as mutually exclusive-worldviews both confidently claiming that masculinity is in crisis. James Heartfield (2002) notes three types of crisis discourse: first, masculinity perceived as pathological (for example, Horrocks, 1996); second, the perception of the death of male pride (for example, Faludi, 1999); third, skeptical responses to crisis discourse (for example, Bruegel, 2000). Heartfield's title, There is No Masculinity Crisis contains his argument in a nutshell, but even if we do not want to deny the realty of the crisis in totality, we can at least see that the conversation is far from new, and has indeed be going on for a long time (Kimmel, 1987).

The crisis of masculinity is used here as a jumping-off point for a new model for thinking about masculinity called the Five Stages of Masculinity (FSM). The model is developmental in nature, and shows the different ways masculinity is framed: both at the macro level (commonly-held worldviews, such as the three types of crisis discourse outlined above), and at the micro level (how an individual can move through FSM on his or her understanding of masculinity). FSM is then, in some ways, a "crisis map." The crisis is most evident at the lower stages of the model and less so at the higher stages; as such, the map leads us away from crisis discourse to a masculinity that is not in crisis.

The following is divided into four parts. First, a discussion of previous models of identity stage development that have paved the way for FSM and the nature of stage structure within FSM. Second, an outline of the specific character of each of the five stages. Third, a preliminary content analysis demonstrating how each of the five stages can be seen in recent news and magazine articles. Fourth, a closing discussion of the implications of FSM for the study of men and masculinities, as well as some new thoughts on the nature of crisis discourse via a mobilization of Giorgio Agamben's concept of the "state of exception" (Agamben, 2005)1. 


\section{Stage Development}

\section{Existing Stage Models}

Identity stage development models have been employed for many years in various contexts, and FSM has echoes of these, albeit not explicitly employing them. For example, William E. Cross (1971) formulated "Nigrescence," which proposed stages of: pre-encounter, encounter, immersion/emersion, internalization, and internalization-commitment ${ }^{2}$. Clearly, Cross sought to outline the development of a minority identity, which is at odds with the current context of masculinity which is normatively dominant. A closer analogy is the white identity development model formulated by Rita Hardiman (1982):

(1) Lack of Social Consciousness which is characterized by a lack of awareness of racial differences and racism; (2) Acceptance, marked by the acceptance of White racist beliefs and behaviors and the unconscious identification with Whiteness; (3) Resistance, characterized by the rejection of internalized racist beliefs and messages and rejection of Whiteness; (4) Redefinition, marked by the development of a new White identity that transcends racism; (5) Internalization, marked by the integration of the new White identity into all other aspects of the identity and into consciousness and behavior ${ }^{3}$.

Cross (1971) proved influential in the realm of identity development in the gendered domain. Nancy E. Downing and Kristin L. Roush (1985) proposed the following stages in the development of women's construction of feminist identity: passive acceptance, revelation, embeddednessemanation, synthesis, and active commitment; a model which has itself been mobilized and extended on numerous occasions (for example, Bargad \& Hyde, 1991; Erchull, et. al., 2009). The intersection of race, gender and staged development has also been explored in the context of masculine identity (Scott \& Robinson, 2001, p. 418). Further still, the development of masculine identity (albeit not necessarily formulated as stages) has been a preoccupation of the psychological study of men and masculinity since the inception of this field, before that in the study of sex roles, and more 
recently to a lesser extent in Critical Studies on Men and Masculinities in the humanities and social sciences.

FSM also shares some commonality with another staged model: that of Ken Wilber's integral theory, which spills over from the developmental into the evolutionary (and thus inhabiting a liminal space between academic and new age thinking). Wilber builds upon Jean Gebser (1985), who suggested evolution unfolded via the following stages: "the archaic, magical, mythical, mental, and integral" (p. 42). Wilber then provides various other lines of development including: the "Great Nest of Being" built on the following trajectory: matter/physics, biology/life, psychology/mind, theology/soul, mysticism/spirit (Wilber, 2000, p. 444); egocentric, ethnocentric and worldcentric (Wilber, 2006, p. 6); and the stages of spiral dynamics developed by Don Edward Beck and Christopher C. Cowan (1996). Integral theory does not see itself as a gendered theory, however its masculine weighting has been noted (Gelfer, 2014; Wright, 1995, 1996).

\section{The Nature of Stages in the Five Stages of Masculinity}

In this initial formulation, FSM is a hypothesis. FSM starts with normative and unchallenged masculinity and works its way up through various levels of critical awareness and analysis. As we rise through the stages, three things happen: first, each stage is inhabited by a decreasing number of people; second, each stage has characteristics that become increasingly complex and more nuanced; third, each stage reveals more methods for identifying and mitigating normative masculinity or-to touch base with the introductory discussion - the crisis of masculinity. A quantitative study of FSM is currently under development to test the accuracy of the FSM hypothesis: specifically, the relative number of people at each stage. The penultimate section below makes some tentative steps in this direction by providing a content analysis of news and media articles sorted by stage.

Before we progress, an important caveat: These are not the stages of masculinity but, rather, some stages of masculinity. Moreover, the stages are porous and overlapping. When visualizing the stages it is tempting to imagine a triangle akin to Maslow's hierarchy of needs (Maslow, 1943). The overall direction of this is sound, but it is too crude. A more useful way of visualizing the stages is a pyramid-shaped Venn diagram, with differentsized circles indicating numbers of inhabitants and clear points of overlap 
(Figure 1). In reality, the stages are more numerous, their characteristics more multifaceted, and their relation less linear. But for the sake of simplicity, the Venn pyramid will serve the purpose.

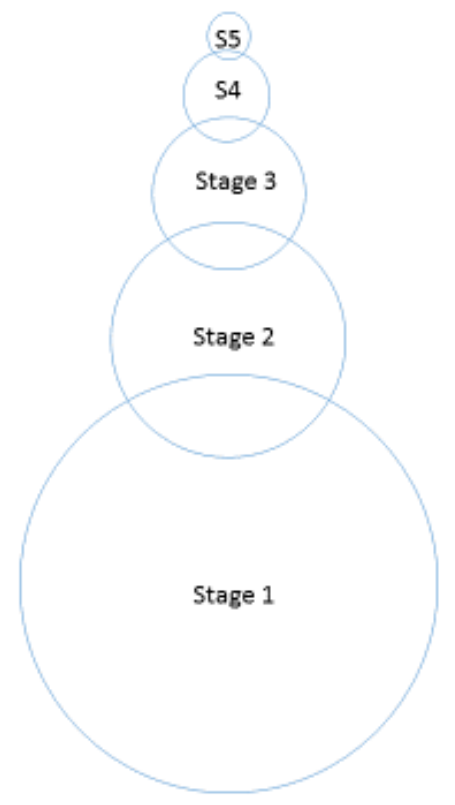

Figure 1. The Five Stages of Masculinity Venn Pyramid

The overlapping and porous nature of the stages also points to the reality of simultaneously existing at different stages in different domains in a way similar to the lines and levels of Wilber's integral theory (Wilber, 2006, pp. 62-64). Another model that normalizes occupying different parts of FSM is the "multiple self-aspects framework" which shows that multiple identities are an inherent part of the ostensibly unitary self, and that we are all "composed of multiple, contextually activated selves" (McConnell, 2011, p. 4). Further still, Hubert Hermans and Harry Kempen (1993) refer to the "dialogical self" in which the self comprises various elements that are in continual dialogue with each other, that permit "one and the same 
individual to live in a multiplicity of worlds with each having its own author telling a story relatively independent of the authors of the other worlds" (p. 46). Within the context of masculine identity, holding different simultaneous positions may even be inevitable (Gelfer, 2012, pp. 134-135). FSM not only allows for this kind of multiplicity, it is a fundamental part of its trajectory (as will be explored in the discussion below of Stage 4 and 5).

A further area of hypothesis is that most people will require moving through each stage as their identity develops over time. This also has precedent in Wilber's integral theory with the notion of "transcend and include" (Wilber, 2006, pp. 128-129) in which levels (or, here, "stages") of personal development eclipse the previous level, thus honoring the partial truth claims revealed within them rather than negating them. Here transcend and include works in two ways: first, how each individual may pass through each stage on their path of identity development; second, how those at higher stages can view the claims of those at lower stages as being relevant to their stage rather than negating them (as will be explored in the discussion below of Stages 3).

As FSM is outlined below there is an inverse proportion of discussion about the stages. In other words, Stage 1 is hypothesized to represent the largest number of people, but is discussed the least; Stage 5 is hypothesized to represent the smallest number of people, but is discussed the most. This imbalance exists because the lower stages are more familiar and have been discussed in the subject literature at length, whereas the higher stages (at least as they are proposed in FSM) have been little discussed, and therefore require greater elaboration simply to articulate FSM in its most basic sense, which is the ultimate objective of this article.

\section{The Five Stages: An Overview}

\section{Stage 1: Unconscious Masculinity}

Stage 1 is defined as "unconscious masculinity," which means that the standard social construction of masculinity has been adopted by someoneboth men and women - without them even thinking about it. Stage 1 is the site where most typical analyses of masculinity take place: normativity masculinity, hegemonic masculinity, homophobia and patriarchy. Stage 1 
thinking is responsible for a good deal of the processes in which masculinity negatively impacts the world: violence, domination, power, economics and the overall mismanagement of the environment.

More people inhabit Stage 1 than any other stage and its mitigation is an enormous challenge for reasons beyond its statistical significance. Chiefly, in Stage 1, normativity, patriarchy and so on are seen as intuitive, common sense, and natural to the point where they are completely internalized and operate under the radar of consciousness and awareness. In order to engage a critical analysis of masculinity at Stage 1, one first needs to bring these issues to consciousness, which is a challenge in itself. Stage 1 masculinity is unconsciously passed on from generation to generation, and has been doing so for thousands of years.

The crisis of masculinity operates at Stage 1, but not — on the groundby using the language of crisis discourse. For example, one can see the crisis at work in the theme of instability of men's identity as workers in the face of globalization (Blossfeld, Mills \& Bernardi, 2006). However, to use the language of crisis discourse in such a context necessitates an awareness of the issue of masculinity that is absent at Stage 1.

\section{Stage 2: Conscious Masculinity}

Stage 2 is defined as "conscious masculinity" and has the most numerous permutations of all the stages. The common thread running through these different permutations is the awareness that there is a level of regulation that takes place around contemporary masculinity. The understanding of that regulation shifts depending on which form of conscious masculinity is embodied. In this initial formulation, FSM divides Stage 2 into four subgroups: Naturalists, Men's Rights Advocates, Spiritualists and Agnostics.

Naturalists are similar to people at Stage 1 inasmuch as they perceive masculinity as intuitive, common sense, and "natural." However, this is a conclusion drawn from contemplation rather than the blind embodiment of unconscious masculinity. Naturalists often believe masculinity is being denied and neutered by modern society. One clear example of a Naturalist is Harvey C. Mansfield whose book Manliness (Mansfield, 2006) seeks to recapture manliness by celebrating its occurrences from as far back as the classical Greeks through to Humphrey Bogart in Casablanca. Naturalists tend to have a conservative vision of masculinity ${ }^{4}$ that upholds the 
unconscious power dynamics of Stage 1 and are firmly rooted in the crisis discourse of the death-of-male-pride variety.

Men's rights advocates identify certain problems with masculinity (such as physical and mental health, education, homelessness, violence, and incarceration) and perceive these to be ignored. Men's rights advocates often believe masculinity is being attacked by feminists (Flood, 2004) and are as such considered to be conservative. Certainly, there is a good deal of clear anti-feminist rhetoric in the men's rights domain, but it is not exclusively so. Indeed, one area that has been glossed over in previous analyses of what are labelled here as Stage 2 subgroups is the internal differences and even schisms between these groups ${ }^{5}$.

Spiritualists are similar to Naturalists inasmuch as believing in an authentic masculinity that should be recovered. They believe models for masculinity can be found in holy texts or more general spiritual principles. Spiritualists often believe masculinity is being denied by a society that has lost its spiritual way. The worldviews and cultural references of Spiritualists differ widely. At one end of the spectrum we can locate a conservative form of masculinity based on Biblical principles, such as the evangelical men's ministry of John Eldredge (2001). Occupying a curiously similar-yet non-Christian-domain we can find Spiritualists such as David Deida (2004) who mixes archetypal masculinity with a form of tantric sexuality. At the other end of the political spectrum we find Spiritualists such as Matthew Fox (2008), who mobilizes a spiritual archetypal masculinity but with a feminist political worldview.

Agnostics are a more general category of people who share certain beliefs with the above forms of conscious masculinity, but not all (in particular, they are put off by the typically conservative agenda). Agnostics generally believe there is a problem with masculinity, but struggle to fully articulate the nature of that problem, let alone a solution.

Stage 2 has the potential to overlap with Stage 1. For example, a men's rights advocate may have a conscious and detailed analytical framework explaining some social aspects of masculinity (such as health) yet operate unconsciously in regard to other aspects (such as fatherhood). Stage overlaps are examples of holding simultaneously different positions, as discussed above. Stage overlaps should, then, not be considered in a negative light. Indeed, areas of overlap are potentially the most fruitful in 
terms of personal change and movement up the stages. Areas of overlap also muddy the waters as to which "camp" a person belongs to: the blurring of these boundaries and the new alliances that can be made as a result are also fruitful.

\section{Stage 3: Critical Masculinities}

Stage 3 is defined as "critical masculinities" and is largely aligned with feminism. Given there are various forms of feminist thinking, there are also various forms of critical masculinities. Some key commonalities that can be found among critical masculinities are: society operates via patriarchy, which oppresses women; society operates via hegemony, which oppresses atypical men (such as gay men and straight men who resist patriarchy); masculinity is not natural, rather socially-constructed; masculinity is not singular, rather plural masculinities (in other words, changeable). Depending on where we are in Stage 3, crisis discourse canvasses "masculinity perceived as pathological" and "skeptical responses to crisis discourse." There is distinct commonality here with Hardiman's Stages 3 and 4 of Whiteness, where an individual comes into awareness of the privileges they enjoy (and the discrimination they have no doubt committed) and seeks to rectify this.

Critical masculinities opens up a sophisticated level of analysis by doing justice - amongst many other things - to the nature of systemic power. This provides our first clear example of how thinking at different stages can often be at cross purposes, and consequently why the arguments between stages seem to never be resolved. In this example we see that Stage 3 looks at patriarchy as a systemic tool for power. However, men's rights advocates at Stage 2 tend to think about men's power not at the systemic level, rather the individual level. From Stage 2, men's power under patriarchy is not a compelling narrative when considered in light of their friends who may be suffering inter-generational unemployment and ill health. In short, Stage 2 privileges individual experience whereas Stage 3 privileges systemic experience, and from their relative stages, both are correct. Of course, both people at Stage 2 and 3 have a responsibility to identify that the other is speaking from a different position. However, following Wilber's 'transcend and include," it is Stage 3 that should have a greater ability of appreciating the position of Stage 2, not the other way around. 
But for all its powerful analyses, Stage 3 has blind spots. As just stated, Stage 3 needs to do a better job of acknowledging the individual experiences of those at Stage $2^{6}$. As alluded to in the discussion of Stage 2, Stage 3 also does a suboptimal job of identifying the nuances of Stage 2, and tends to lump together all its sub-groups rather than acknowledging its constituent parts and internal schisms. This is something of a paradox, because while one of the characteristics of Stage 3 is the acknowledgement of plural masculinities, there is an odd resistance to acknowledging the existence of this plurality at Stage 2 .

A further limiting factor to Stage 3 is a tendency towards essentialism. The category of "man" and "woman"-so fundamental to feminist thought-assumes a commonality within those categories that can be hard to justify. Indeed, in Stage 3 those categories of "man" and "woman" can look suspiciously like Stage 2 Naturalists ${ }^{7}$. Sometimes, those Stage 3 essentialisms may be strategic (such as Luce Irigaray's mimesis), sometimes they are not (Stone, 2004).

\section{Stage 4: Multiple Masculinities}

Stage 4 is defined as "multiple masculinities" and is largely aligned with queer theory. FSM interprets queer theory as broader than the experiences of LGBTQ people, instead using it as a way to trouble categories for people of any and every sexual orientation. Stage 4 is thus based on three fundamentals: first, masculinity can mean anything to anyone (including being embodied by women); second, masculinity is defined and categorized through power dynamics such as patriarchy and hegemony as a way of regulating people; third, by rejecting categorization we subvert regulation and power.

Thanks to the decades of struggle by LGBTQ people, queer theory has opened up an extraordinary number of possibilities. As such, Stage 4 sees a temporal shift in orientation. Stage 1-being unconscious of the construction of masculinity - is largely atemporal in conscious thought and historical in unconscious thought. Stage 2 is firmly historical in its perception of masculinity. Stage 3 is also largely historical as its project is one of demonstrating the historical norm of patriarchy: it also has a secondary focus on the present, exemplified by a discourse of equality and 
gender mainstreaming. Stage 4 starts with a focus on the present, but is ultimately future-orientated. The queerness of Stage 4 is about opening up possibilities, and not just modest possibilities that tinker with the status quo, rather fully Utopian possibilities (Drucker, 2015). At Stage 4, no longer is there masculinity and femininity (or even, really, men and women). Instead, each individual dwells in a category of sex and gender as unique as their fingerprint. Crisis discourse is not particularly important at Stage 4, unless its inhabitants are noting the problem people at lower stages have with Stage 4 masculinities. Indeed, as well as a temporal shift, Stage 4 is also the first stage that points away from the crisis (whichever of its three varieties) to some altogether different territory.

Despite the fact that queer theory is so potent, it is also wildly underutilized, due to the common perception that it is only about LGBTQ people. The experiences of LGBTQ people are simply an amplification of the masculinity regulation that happens to everyone. All straight-identifying men should have an interest in this because it is only a few short steps from men being shut down for having a queer sexual orientation to being shut down for holding any counter-normative position: The "queer issue" is, therefore, not a "queer issue," rather an "everybody issue." As Marcella Althaus-Reid says, "Let us remember here that the Genderfucker may also be straight" (Althaus-Reid, 2003, p. 68).

There are a couple of drawbacks to queer theory, and with it Stage 4. First, despite its promises for all people, it is difficult for people who are not "gay" to fully get behind it. Second, queer theory and Stage 4 can also be subject to slipping into essentialism, which runs counter to the spirit of Stage 4. For example, it is inconsistent to work against the regulatory function of gender and sexuality categorization, yet routinely describe people as "straight" or "cis," when this serves little purpose other than to place people in a category based on their gender and sexuality. Stage 4 also leaves us with a lingering question: If masculinity can mean anything you want it to mean, does it have any meaning at all?

\section{Stage 5: Beyond Masculinities}

Stage 5 is defined as "beyond masculinities" and begins to tackle the fundamentally ontological question posed by the implications of Stage 4. It 
is hypothesized that very few people consciously operate at Stage 5, although a larger number of people probably intuit its presence. The bottom line of Stage 5 is the simple truth that masculinity does not exist. As such, when there is no masculinity, there can be no crisis of masculinity. However, it is difficult to connect the dots for those at earlier stages and move them towards solutions to the problems of normative masculinity when one has to eventually concede that masculinity is not real (in which case, how can it cause a problem!). Of course, it is the reification of masculinity that is the problem. In other words, masculinity exists as a consensual hallucination which nevertheless has many real effects. Even so, the Stage 5 mind still wants to bring form to the concept of masculinity, as its eventual non-existence seems a rather cruel existential joke. As such, following are two tools and that can be employed to fashion some form out of Stage 5, acknowledging that we are teetering on the very edge of language: the first conceptual, the second methodological.

The first tool comes in the psychoanalytic concept of "individuation," the process where individual consciousness is brought into being. "Preindividuation" can be seen as the primordial state before personal identityand with it, masculinity - is established. Locating masculinity in the space of pre-individuation would suggest a reversion to the womb, but "postindividuation" could be a space that resists the identity bestowed by individuated masculinity while remaining conscious of its nature. One vision of this space-oscillating between pre- and post-individuation - can be found in the "matrixial borderspace" of Bracha Ettinger (2004). Despite suggestions that the matrix is pre-ontological and thus pre-identity (Butler, 2004, p. 98), Ettinger articulates this space in an elusive manner that seems to fit Stage 5: "a web of movements of borderlinking, between subject and object, among subjects and partial-subjects, between me and the stranger, and between some partial-subjects and partial objects" (p. 76). Ettinger's matrix is ostensibly "feminine" which also appears to problematize its inclusion as Stage 5. However, "the feminine under the Matrix marks not the phallus-negated other, but a different site of sexual difference that is not about binary logic" (Pollock, 2004, p. 11), which fits well with Stage 5. In short, Ettinger's matrix is useful for Stage 5 as it is conscious of gendered identity, yet looks beyond this to a place where both the subject-object relationship and gendered identity has dissolved ${ }^{8}$. 
The second tool is a method the medieval Christian mystics used for speaking about God called the "via negativa"-or apophatic theology (Davies \& Turner, 2002) — which seeks to describe God not by what S/he is but by what $\mathrm{S} / \mathrm{he}$ is not. This process aspires to bring form to the experience of God while accepting that $\mathrm{S} / \mathrm{he}$ is ultimately beyond human perception. The via negativa could similarly be used to think around masculinity: if not to say what it is, then at least to answer attempts to contain and regulate it. People who are not sympathetic to a spiritual worldview may turn off at this point, but this is not some covert attempt to evangelize. This tool works just as well for atheists as spiritual people. It just so happens that religion has an extensive history of articulating the beyond, and in the end, Stage 5 is not a stage, rather a signpost to somewhere else.

\section{The Five Stages: A Content Analysis}

In the FSM hypothesis discussed above it was proposed that the number of people inhabiting each stage decreases with each stage (in other words, the largest number of people inhabit Stage 1, the smallest number of people inhabit Stage 5). A quantitative study is currently underway to identify what percentage of people operate at each of the five stages. However, to provide some preliminary context for this forthcoming study, a content analysis was undertaken to sort news and magazine articles by stage to indicate the level of public conversation at the different stages. For a duration of two months (January and February 2016), English language news and magazine articles were monitored via daily Google news searches on the terms "masculinity" and "masculinities"; the same terms were monitored daily on Twitter. The way each article framed masculinity was allocated to the appropriate stage in FSM: for example, an article that discussed how masculinity oppressed women was assigned to Stage 3; an article that discussed how masculinity was lacking in society was assigned to Stage 2 . The articles identified are by no means exhaustive, but nevertheless serve as an indicative overview of this period. The list avoids articles on the same subject unless there is a significant departure in content. For example, there were three stories in this period that generated huge numbers of articles, but this is not apparent from the list: Donald Trump and how masculinity was mobilized in the 2016 presidential campaign; Jaden Smith's modeling for Louis Vuitton's 


\section{Gelfer - The Five Stages of Masculinity}

women's collection and his impact on black masculinity; Roosh V's neomasculinity meet-ups and the consequent international backlash. Appendix 1 provides a list of 51 news and magazine articles from this period. Sorted by stage, the article breakdown is as follows: twelve articles at Stage 1; ten articles at Stage 2; 17 articles at Stage 3; ten articles at Stage 4; two articles at Stage 5.

Following the Venn pyramid offered in Figure 1, one would expect Stage 1 articles to be the most numerous. This was not the case, but there are plausible explanations for this. The simple act of engaging the terms "masculinity" and "masculinities" that would flag the articles for inclusion in the content analysis suggests a consciousness of the subject that transcends the definition of Stage 1. Indeed, Stage 1 articles are largely articles written about Stage 1, not from Stage 1. This in turn raises an interesting question about how articles are sorted. Is a Stage 3 critique of Stage 1 allocated to Stage 3 or Stage 1? In these instances, articles have been sorted by the stage we learn most about: the source or the object of criticism. As expected, Stage 1 articles contain the standard masculine signifiers: sex, sport, violence, and meat consumption. If numerous similar articles about Trump, masculinity and politics had also been counted the number of Stage 1 articles would have been significantly higher.

Stage 2 articles should be less in number than Stage 1, which is supported by the article breakdown. Hanging over from Stage 1, politics makes an appearance at Stage 2, along with mainstream cultural products. If numerous similar articles about Roosh V's neo-masculinity meet-ups had also been counted the number of Stage 2 articles would have been significantly higher.

Stage 3 articles should be smaller in number than Stage 2, but proved the largest in number of all the stages. Stage 3 articles were mostly represented by more subtle masculine performances in cinema, television and literature. One can speculate that the reason that Stage 3 has a greater representation among the articles than expected is due to the worldview of the people who typically produce media content, who are not statistically representative of society in general.

Stage 4 articles are predictably smaller in number and queer in theme. It is important to remember that Stage 4 is not LGBTQ-queer, rather category-troubling-queer. As such, while the number of articles at Stage 4 
are small, it is possible that there were more applicable articles out there that were using the vocabulary of queerness rather than the terms "masculinity" and "masculinities," and as such were not caught by the capturing method of the content analysis. If the number of articles were indeed higher, this would again be disproportionately high, and again would be speculatively attributable to the fact that people who typically produce media content are more interested in this theme than society in general.

Stage 5 articles were particularly small in number, which was to be expected. As Stage 5 is really a signpost to somewhere else rather than a specific stage, and because Stage 5 is operating at the edge of language, Stage 5 is the least likely to have been caught by the capturing method of the content analysis. There were only two Stage 5 articles: one talking about the erasure of "he" and she" in favor of "zhe," and another calling for the removal of gender from UK passports and driving licenses. Both these articles have interesting things to say about how language and categorization might impact people's perceptions of self in regard to masculinity.

\section{Conclusion}

The crisis of masculinity was used as a jumping-off point to consider the different ways people perceive masculinity. Heartfield's three types of crisis discourse included: masculinity perceived as pathological; the perception of the death of male pride; skeptical responses to crisis discourse. FSM was introduced as a model for viewing a large spectrum of perceptions about masculinity, and from a theoretical perspective, we saw how these three different forms of crisis discourse can be located on FSM and how identifying the crisis discourse (and indeed, all gender politics) from within the relevant stage rather than from another stage has the potential to de-escalate groups talking at cross-purposes. From a more "real life" perspective, the content analysis demonstrated how public conversations about masculinity can be mapped onto FSM and offers an indication of which stage can be allocated to most public conversation about masculinity (albeit not necessarily being replicable to society in general). 
There is another vision of crisis discourse that does not appear to have been explored that can be surfaced via a reading of Giorgio Agamben's concept of the "state of exception" (Agamben, 2005). Similar to a state of emergency, the state of exception is used by governments to leverage exceptional powers that inevitably curtail the freedoms of citizens. Reinforcing Walter Benjamin's assertion that "the state of emergency in which we live is not the exception but the rule" (Benjamin, 2003, p. 392), Agamben (2014) argues we are now "having to face a continuous state of exception." This continuous state of exception has an application to the crisis of masculinity when we consider the two as, in effect, synonymous. For some groups at Stage 2 it makes absolute sense to cast masculinity in crisis, as to do so invokes exceptional powers to assert normative masculinity that in non-exceptional circumstances might appear unreasonable. The crucial pivot here is that masculinity is not in crisis, rather masculinity demands crisis. To stay within the material of the above content analysis, if Donald Trump and Roosh $\mathrm{V}$ did not have a crisis to which to respond, they would have nothing at all.

The trajectory of FSM moves away from crisis discourse. It does not seek to counter the demand for crisis with an analysis of the validity of crisis, rather by having an altogether different conversation (a tactic that online commentators of Donald Trump and Roosh V could learn from). And herein lies the great potential for FSM: the ability to have a different conversation. There are a limited number of choices in how one typically approaches the study of men and masculinities: Critical Studies on Men and Masculinities, which is largely a subset of regular Women's Studies; Men's Studies, which is sometimes considered politically ambiguous (Hearn \& Pringle, 2006, p. 5); Male Studies, which is largely reactionary in nature; Queer Studies, which is largely concerned with the experiences of LGBTQ people. All these approaches have elements of value (some more than others), but all have their limitations and a habit of constructing new orthodoxies while simultaneously attempting to deconstruct the old. FSM provides an opportunity to take something from all these approaches and does not have an endgame - yet another new orthodoxy-rather, it points to something undefined that is yet to come. 


\section{MCS - Masculinities and Social Change, 5(3) 285}

\section{Notes}

${ }^{1}$ Thanks to Bill Harryman and Sarah Nicholson for their thoughts on the initial formulation of FSM.

${ }^{2}$ Cross went on to refine this model over time (for example, Cross, 1995).

${ }^{3}$ As outlined in the doctoral abstract of Hardiman (1982).

${ }^{4}$ The characterization of Mansfield as a conservative is not suggested just by his position on masculinity. Jane Mayer (2016) documents that Mansfield has been the recipient of significant amounts of funding from right-wing foundations, along with another Naturalist - George Gilder-who has written about conservative and natural sex roles for men and women (Gilder, 1986) and who straddles the Stage 2 sub-groups of Naturalist and Spiritualist.

5 Such schisms are demonstrated in the articles gathered in the content analysis exercise below. One masculinity story that garnered enormous global attention during the analysis time period was the planned global meet-ups of neo-masculinity groups led by Roosh V. Roosh V was routinely described as a "men's rights advocate" (for example, Farthing, 2016), however it is common to find both Roosh V and men's rights advocates making it clear they do not share the same agenda.

6 This is arguably a natural extension of intersectionality. Indeed, it is surprising that the more intellectually-inclined men's rights advocates have not mobilized intersectionality in response to what they would perceive as the multiple factors that combine to problematize an uncritical acceptance of patriarchy.

7 This slippage in stages also has an analogy with Wilber, who proposed the "pre/trans fallacy" (Wilber, 2000, p. 212), where worldviews of lower stages can be mistakenly elevated to higher stages, and those of higher stages reduced to lower stages.

${ }^{8}$ Something similar might be seen in Deleuze's spatial metaphors: "The variability, the polyvocality of directions, is an essential feature of smooth spaces of the rhizome type, and it alters their cartography. The nomad, nomad space, is localized and not delimited" (Deleuze \& Guattari, 1987, p. 382). Further still, a spiritual form of this comes in the Eastern concept of Ātman, which represents one's eternal soul or essence. In this context, masculinity is but one of many illusions from which we must be liberated before experiencing transcendence.

\section{References}

Althaus-Reid, M. (2003). The queer God. London: Routledge. Agamben, G. (2005). States of exception. Chicago: University of Chicago Press.

Agamben, G. (2014, February 25). The security state and a theory of destituent power. Philosophers for Change [Web log post]. Retrieved 
from http://philosophersforchange.org/2014/02/25/the-security-stateand-a-theory-of-destituent-power/.

Bargad, A., \& Hyde, J. S. (1991). Women's studies: A study of feminist identity development in women. Psychology of Women Quarterly, 15(2), 181-201. doi:10.1111/j.1471-6402.1991.tb00791.x

Beck, D. E., \& Cowan, C. C. (1996). Spiral dynamics: Mastering values, leadership, and change: Exploring the new science of memetics.

Cambridge, MA: Blackwell Business.

Benjamin, W. (2003). On the concept of history. In H. Eiland \& M. W. Jennings (Eds.), Walter Benjamin: Selected writings, (Vol. 4, 19381940). Cambridge, MA: Harvard University Press.

Blossfeld, H.-P., Mills, M., \& Bernardi, F. (Eds.). (2006). Globalization, uncertainty and men's careers: An international comparison.

Cheltenham: Edward Elgar Publishing.

Bruegel, I. (2000). No more jobs for the boys? Gender and class in the restructuring of the British economy. Capital \& Class, 24(2), 79-102. doi:10.1177/030981680007100104

Butler, J. (2004). Bracha's Eurydice. Theory, Culture \& Society, 21(1), 95100. doi:10.1177/0263276404040481

Cross, W. E. (1971). The negro to black conversion experience. Black World, 20(9), 13-27.

Cross, W. E. (1995). The psychology of Nigrescence: Revising the Cross model. In in J. G. Ponterotto, J. M. Casas, L. A. Suzuki, \& C. M. Alexander (Eds.), Handbook of multi-cultural counselling (pp. 93-122). Thousand Oaks, CA: Sage.

Davies, O., \& Turner, D. (Eds.). (2002). Silence and the word: Negative theology and incarnation. Cambridge: Cambridge University Press.

Deida, D. (2004). The way of the superior man: A spiritual guide to mastering the challenges of women, work and sexual desire (2nd ed.). Boulder, CO: Sounds True.

Deleuze, G., \& Guattari, F. (1987). A thousand plateaus: Capitalism and schizophrenia. Minneapolis: University of Minnesota Press.

Downing, N. E., \& Roush, K. L. (1985). From passive acceptance to active commitment: A model of feminist identity development for women. The Counseling Psychologist 3(4), 695-709.

doi:10.1177/0011000085134013 
Drucker, P. (2015). Warped: Gay normality and queer anti-capitalism. Leiden: Brill.

Erchull, M. J., et. al. (2009). The feminist identity development model:

Relevant for young women today? Sex Roles 60(11), 832-842.

doi:10.1007/s11199-009-9588-6

Ettinger, B. (2004). Weaving a woman artist with-in the matrixial encounter-event. Theory, Culture \& Society 21(1), 69-94.

doi:10.1177/0263276404040480

Eldredge, J. (2001). Wild at heart: Discovering the secret of a man's soul. Nashville, TN: Nelson Books.

Faludi, S. (1999). Stiffed: The betrayal of the modern man. London: Chatto \& Windus.

Farthing, M. (2016, February 3). Men's rights activist threatens to enter Australia against its consent. The UnAustralian. Retrieved from: http://theunaustralian.net/2016/02/03/mens-rights-activist-threatens-toenter-australia-against-its-consent/

Flood, M. (2004), Backlash: Angry men's movements. In S. E. Rossi, The battle and backlash rage on: Why feminism cannot be obsolete (pp. 261-278). Philadelphia, PA: Xlibris.

Fox, M. (2008). The hidden spirituality of men: Ten metaphors to awaken the sacred masculine. Novato, CA: New World Library.

Gebser, J. (1985). The ever-present origin. Athens, OH: Ohio University Press.

Gelfer, J. (2012). Will the real Joseph Gelfer please stand up: Multiple masculinities and the self. NORMA: Nordic Journal for Masculinity Studies, 7(2), 125-138. Retrieved from

https://www.idunn.no/norma/2012/02/will_the_real_joseph_gelfer_pleas e_stand_up_multiple_mascu?mode=author_info_ID_G1896536927\&ski pDecorating=true

Gelfer, J. (2014). Integral spirituality or muscular spirituality? In S. E. Nicholson \& V. D. Fisher (Eds.), Integral voices on sex, gender, and sexuality (pp. 187-207). Albany, NY: SUNY Press.

Gilder, G. F. (1986). Men and marriage. Gretna: Pelican Pub. Co. Hardiman, R. (1982). White identity development: A process oriented model for describing the racial consciousness of White Americans. Doctoral Dissertation, University of Massachusetts - Amherst. 
Hearn, J., \& Pringle, K. (2006). Studying men in Europe. In J. Hearn \& K. Pringle (Eds.), European perspectives on men and masculinities: National and transnational approaches (pp. 1-19). Basingstoke: Palgrave.

Heartfield, J. (2002). There is no masculinity crisis. Genders, 35. Retrieved from http://www.colorado.edu/AmStudies/lewis/film/nomalecrisis.pdf

Hermans, H., \& Kempen, H. (1993). The dialogical self: Meaning as movement. San Diego, CA: Academic Press.

Horrocks, R. (1996). Masculinity in crisis. London: Macmillan.

Kimmel, M. S. (1987). The contemporary "crisis" of masculinity in historical perspective. In H. Brod (Ed.), The making of masculinities: The new men's studies (pp. 121-153). Boston: Allen \& Unwin.

Mansfield, H. (2006). Manliness. New Haven, CT: Yale University Press.

Maslow, A. H. (1943). A theory of human motivation. Psychological Review, 50(4), 370-396. doi:10.1037/h0054346

Mayer, J. (2016). Dark money: The hidden history of the billionaires behind the rise of the radical right. New York: Doubleday.

McConnell, A. R. (2011). The multiple self-aspects framework: Selfconcept representation and its implications. Personality and Social Psychology Review, 15(1), 3-27. doi:10.1177/1088868310371101

Pollock, G. (2004). Thinking the feminine: Aesthetic practice as introduction to Bracha Ettinger and the concepts of matrix and metramorphosis. Theory, Culture \& Society, 11(1), 5-65. doi:10.1177/0263276404040479

Scott, D. A., \& Robinson, T. L. (2001). White male identity development: The key model. Journal of Counseling \& Development, 79(4), 415-421. doi:10.1002/j.1556-6676.2001.tb01988.x

Stone, A. (2004). Essentialism and anti-essentialism in feminist philosophy. Journal of Moral Philosophy 1(2), 135-153.

doi:10.1177/174046810400100202

Wilber, K. (2000). Sex, ecology, spirituality: The spirit of evolution (2nd ed.). Boston: Shambhala.

Wilber, K. (2006). Integral spirituality: A startling new role for religion in the modern and postmodern world. Boston: Integral Books. 
Wright, P. A. (1995). Bringing women's voices to transpersonal theory. ReVision 17(3), 3-11. Retrieved from http://www.revisionpublishing.org/pastissues.html\#vol18 Wright, P. A (1996). Gender issues in Ken Wilber's transpersonal theory. ReVision 18(4): 25-37. Retrieved from http://www.revisionpublishing.org/pastissues.html\#vol18

Joseph Gelfer is adjunct Research Associate at University of Divinity, Australia

Contact Address: Direct correspondence to Joseph Gelfer at University of Divinity, 21 Highbury Grove, Kew VIC 3101, Australia, E-mail: joseph@gelfer.net

\section{Appendixes}

Appendix A

News and Magazine Article Sorted by the Five Stages of Masculinity

\section{Stage 1}

Teenage boys' attitudes to risky sex 'can help predict what type of father they will be': http://www.independent.co.uk/life-style/love-sex/youngmale-attitude-to-risky-sex-can-predict-their-attitudes-to-fatherhoodnorthwestern-school-of-a6893321.html

From jousting to football: The ideal man hasn't changed much since medieval times: http://theconversation.com/from-jousting-to-football-theideal-man-hasnt-changed-much-since-medieval-times-54920

Men think they need to eat meat to be manly — and it's making them sick: http://qz.com/622306/men-think-they-need-to-eat-meat-to-be-manlyand-its-making-them-sick/ 
Masculinity continues to be the norm in Punjab: http://www.tribuneindia.com/news/comment/masculinity-continues-to-bethe-norm-in-punjab/198550.html

Manliness is a warm gun: http://takingnote.blogs.nytimes.com/2016/02/12/manliness-is-a-warm-gun/

What the Malheur Occupation teaches us about masculinity: http://www.huffingtonpost.com/susan-m-shaw/what-malheur-occupationpatriarchy-masculinity_b_9116064.html

Boots? Marco Rubio wants to talk guns and football: http://www.nytimes.com/2016/01/19/us/politics/boots-marco-rubio-wantsto-talk-guns-and-football.html

Meat heads: New study focuses on how meat consumption alters men's self-perceived levels of masculinity: http://www.huffingtonpost.com/zoeeisenberg/meat-heads-new-study-focuses_b_8964048.html

Trump's angry white men: http://www.theguardian.com/usnews/2016/jan/08/angry-white-men-love-donald-trump

Obama's tears, America's tragedy: http://www.salon.com/2016/01/06/obamas_tears_americas_tragedy_behind _fox_news_mockery_lies_uncomfortable_truth_about_our_failed_politics/

Odell Beckham Jr. vs. toxic black masculinity: http://www.slate.com/blogs/outward/2015/12/29/odell_beckham_jr_gay_ru mors_show_the_problem_with_black_masculinity.html

Murder in the suburbs: chilling book investigates masculinity in Australia: http://www.theguardian.com/books/2016/jan/30/in-the-suburbschilling-book-investigates-masculinity-in-australia

\section{Stage 2}

Final Fantasy VII's Barret portrays positive virtues of masculinity: http://blacktridentmedia.com/2016/02/03/barret-portrays-positive-virtuesof-masculinity/

Wanted in China: More male teachers, to make boys men: http://www.nytimes.com/2016/02/07/world/asia/wanted-in-china-moremale-teachers-to-make-boys-men.html?_r=0 
Brands are challenging the worst parts of masculinity, just in time for the Super Bowl: http://qz.com/606392/brands-are-creating-super-bowlcommercials-that-challenge-the-worst-parts-of-masculinity/

Daryush 'Roosh V' Valizadeh cancels neo-masculinist meetings over safety: http://www.theguardian.com/australia-news/2016/feb/04/daryushroosh-v-valizadeh-cancels-neo-masculinist-meetings-over-safety

'Goat' takes aim at college frat hazing, modern masculinity: http://www.thewrap.com/goat-takes-aim-at-college-frat-hazing-modernmasculinity-with-help-from-nick-jonas/

Europe's tragedy: Too much Angela Merkel, too little masculinity: https://www.rt.com/op-edge/329241-europes-tragedy-merkel-immigration/

Creed and the secrets of a male tear-jerker:

http://www.independent.co.uk/arts-entertainment/films/features/creed-andthe-secrets-of-a-male-tear-jerker-from-field-of-dreams-to-good-willhunting-a6796501.html

The long, bristly history of beards and masculinity: http://www.slate.com/articles/arts/books/2016/01/of_beards_and_men_a_hi story_of_beards_by_christopher_oldstone_moore_reviewed.html

Star Wars: Men's rights activists claim boycott cost The Force Awakens \$4.2m: http://www.independent.co.uk/arts-entertainment/films/news/starwars-mens-rights-activists-claim-boycott-cost-the-force-awakens-42ma6796146.html

The relationship between Muslim men and their beards is a tangled one: http://www.theguardian.com/commentisfree/2016/jan/28/muslim-menbeards-facial-hair-islam

\section{Stage 3}

Lego creates stay-at-home hipster dad figurine: http://www.telegraph.co.uk/news/newstopics/howaboutthat/12169574/Lego -creates-stay-at-home-hipster-dad-figurine.html

Sense and Sensibility and Jane Austen's accidental feminists: http://www.theatlantic.com/entertainment/archive/2016/02/sense-andsensibility-jane-austen-emma-thompson/434007/

There's more than one way of being a black man: http://www.voiceonline.co.uk/article/there $\%$ E2\%80\%99s-more-one-way-being-black-man 
How to be a man: A new generation of artists is rethinking the meaning of masculinity in Russia:

http://calvertjournal.com/features/show/5472/post-soviet-youthmasculinity-boyhood-Russia

How to be a good dad in 2016: http://uk.askmen.com/dating/single_fathers/how-to-be-a-good-dad-in2016.html

The Deadpool phenomenon and the American male: http://www.newyorker.com/culture/richard-brody/the-deadpoolphenomenon-and-the-american-male

University isn't for men? No one told me or my students: https://www.timeshighereducation.com/blog/university-isnt-men-no-onetold-me-or-my-students

Cam Newton and the burden of history: http://www.thenation.com/article/cam-newton-and-the-burden-of-history/

The violence behind the words 'be a man': http://www.alternet.org/sexamp-relationships/violence-behind-words-be-man

Have Jews become obsessed with bro masculinity?: http://forward.com/opinion/333116/have-jews-become-obsessed-with-bromasculinity/

As a male feminist, I feel sorry for Roosh V's weak and easily manipulated 'neo-masculine' supporters:

http://www.independent.co.uk/voices/as-a-male-feminist-i-feel-sorry-forroosh-vs-easily-manipulated-neo-masculine-supporters-a6855746.html

Nobody has to "man up" here: Feminist shows "Jessica Jones" and "Transparent" are also a win for men:

http://www.salon.com/2016/01/22/nobody_has_to_man_up_here_feminist_ shows_jessica_jones_and_transparent_are_also_a_win_for_men/

'Mad Dogs' doesn't celebrate American masculinity, it mourns it: http://decider.com/2016/01/22/mad-dogs-amazon-prime-loss-of-americanmasculinity/

Tom Hardy on being a real man: https://www.redbulletin.com/us/us/culture/tom-hardy-knows-what-being-areal-man-means 
The athlete demolishing misconceptions about masculinity: http://www.sbs.com.au/topics/sexuality/article/2016/01/15/athletedemolishing-misconceptions-about-masculinity

College students join hands to redefine 'Mardangi': http://www.mumbaimirror.com/mumbai/others/College-students-joinhands-to-redefine-Mardangi/articleshow/50505040.cms

Colombia's peace requires disarming manhood, not just men: http://linkis.com/newint.org/blog/2016/AzI8H

\section{Stage 4}

Tiger Maremela uses digital collage to examine black masculinities in the "Rainbow Nation": http://www.designindaba.com/articles/creativework/tiger-maremela-uses-digital-collage-examine-black-masculinities$\%$ E2\%80\%9Crainbow

Why men fight: An empirical investigation of the extremes of masculinity: http://qz.com/613980/why-men-fight-an-empiricalinvestigation-of-the-extremes-of-masculinity/

Bro is an app that encourages men to explore sexual fluidity while retaining masculinity: http://hop.media/read/culture/bro-app

If a man with a vagina can be just as masculine as one with a penis, then just watch the patriarchy crumble: http://www.huffingtonpost.com/daniellyons/if-a-man-with-a-vagina-ca_b_9263132.html

Jaden Smith's adventures in gender fluidity: What it means, who profits: http://www.thewrap.com/jaden-smiths-adventures-in-gender-fluidity-whatit-means-who-profits/

What I learned from being non-binary while still being perceived as a man: http://everydayfeminism.com/2016/02/genderqueer-amab-experience/

Gender fluidity has a toxic masculinity problem: http://www.thedailybeast.com/articles/2016/02/03/gender-fluidity-has-atoxic-masculinity-problem.html

How David Bowie changed the face of modern masculinity: http://www.telegraph.co.uk/men/thinking-man/how-david-bowie-changedthe-face-of-modern-masculinity/ 
294 Gelfer - The Five Stages of Masculinity

Are feminism and the transgender movement at odds?

http://www.huffingtonpost.com/isaac-fornarola/are-feminism-and-thetran_b_8882764.html

Living with a controversial Catholic sect helped me lose my religion and leave masculinity behind: http://www.vice.com/en_uk/read/living-withopus-dei-student-390

\section{Stage 5}

That's what zhe said: As genders blur, language is rapidly adapting: http://www.alternet.org/news-amp-politics/thats-what-zhe-said-gendersblur-language-rapidly-adapting

Call to remove gender from UK passports and driving licences: http://www.theguardian.com/world/2016/jan/02/call-to-remove-genderfrom-uk-passports-and-driving-licences 
Instructions for authors, subscriptions and further details:

\section{http://mcs.hipatiapress.com}

\section{Licencias de Paternidad y Permisos Parentales en América Latina y el Caribe. Herramientas Indispensables para Propiciar la Mayor Participación de los Padres en el Cuidado de los Hijos e Hijas}

Carina Lupica ${ }^{1}$

1) Observatorio de la Maternidad, Argentina

Date of publication: October $21^{\text {st }}, 2016$

Edition period: February 2017 - June 2017

To cite this article: Lupica, C. (2016). Licencias de paternidad y permisos parentales en América Latina y el Caribe. Herramientas indispensables para propiciar la mayor participación de los padres en el cuidado de los hijos e hijas. Masculinities and Social Change,5(3),295-320. doi:

10.17583/MCS.2016.2083

To link this article: http://doi.org/10.17583/MCS.2016.2083

PLEASE SCROLL DOWN FOR ARTICLE

The terms and conditions of use are related to the Open Journal System and to Creative Commons Attribution License (CC-BY). 
MCS - Masculinities and Social Change Vol. 5 No. 3 October 2016

pp. 295-320

\section{Paternity and Parental Leave in Latin America and the Caribbean. Essential Tools to Promote Greater Participation of Fathers in the Care of Children}

Carina Lupica

Observatorio de la Matenidad

\section{Abstract}

Institutional reform becomes necessary to accompany the entry of women into the labor market and promote greater involvement of men in caring for their children in most countries of Latin America and the Caribbean. So that both partners have a paid job and, in turn, exercise their shared parental responsibilities, it is required to extend to male workers care guarantees that are not exclusively linked to the biological reproductive role of women: pregnancy, childbirth and lactation. In that sense, paternity and parental leaves are useful tools to advance from the world of work towards overcoming the old model of "the male breadwinner and female housewife." However, these important changes alone are not enough. The implementation of positive actions is essential to stimulate the cultural change needed in order to foster a new perception of workers regarding family commitments

Keywords: parenthood, paternity, gender, work, care. 
MCS - Masculinities and Social Change Vol. 5 No. 3 October 2016

pp. 295-320

\section{Licencias de Paternidad y}

Permisos Parentales en América

Latina y el Caribe. Herramientas

Indispensables para Propiciar la

Mayor Participación de los

Padres en el Cuidado de los Hijos

e Hijas

Carina Lupica

Observatorio de la Matenidad

\section{Resumen}

En la mayoría de los países de América Latina y el Caribe se vuelve necesaria una reforma institucional que acompañe la incorporación de las mujeres al mercado de trabajo y promueva la mayor participación de los hombres en el cuidado de sus hijos e hijas. Para que ambos miembros de la pareja puedan trabajar de manera remunerada y, a su vez, ejercer las funciones parentales de manera compartida, se requiere extender a los trabajadores masculinos las garantías de cuidado que no están ligadas a la función exclusivamente reproductiva biológica de las mujeres: el embarazo, el parto y la lactancia. En ese sentido, las licencias de paternidad y los permisos parentales son herramientas útiles para avanzar, desde el mundo del trabajo, hacia la superación del viejo modelo "hombre proveedor y mujer dueña de casa". Sin embargo, estas importantes mutaciones no serán suficientes por sí solas. También se requiere la implementación de acciones positivas que posibiliten el cambio cultural necesario para fomentar una nueva percepción de los trabajadores ante los compromisos familiares.

Palabras clave: paternidad, maternidad, género, trabajo, cuidados.

2016 Hipatia Press

ISSN: 2014-3605

DOI: $10.17583 / \mathrm{MCS} .2016 .2083$ 


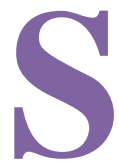

er padre es un proceso gradual que comienza con la decisión de tener y hacerse cargo de la protección, provisión y crianza de un niño o niña. Así, la paternidad incorpora la función proveedora material, la provisión de cuidados y la creación de lazos afectivos firmes y permanentes, que requieren mayor cercanía de los hombres con los niños/as (Oiberman, 1998; UNFPA-CEPAL, 2005).

Los hombres establecen con sus hijos/as una relación en el marco de una práctica compleja en la que intervienen factores sociales y culturales, que se modifican a lo largo del ciclo de vida del padre y de los niños/as. La paternidad es entonces un fenómeno cultural, social y subjetivo que relaciona a los hombres con sus hijos/as, más allá de cualquier tipo de arreglo conyugal (CEPAL, 2001, citado en Ugalde, 2008).

En diversas investigaciones se ha usado la expresión "trabajo del padre" en lugar de paternidad para centrarse en lo que los hombres hacen realmente en sus papeles paternales y también para enfatizar que el conjunto de habilidades y comportamientos que incluye el ejercicio de la paternidad, se pueden aprender (NCFR, 2003; Brown, 2004, citados en Lupica 2011).

La concepción y las características de las funciones paternas se han modificado a lo largo del tiempo, acordes con el desarrollo de las sociedades. En la actualidad, se asiste a un momento de mayor diversidad de estructuras y dinámicas familiares, dentro de las cuales conviven variados modos de concebir y ejercer la paternidad. Se puede ser un padre ausente, próximo o protagónico en la crianza de los hijos/as. Se puede ser padre por azar, sin haberlo elegido ni deseado (fundamentalmente, los adolescentes). Se puede ser padre no biológico ante la conformación de familias ensambladas, por reproducción asistida, en parejas del mismo sexo e incluso sin la presencia de la madre (Valdés, 2009).

Uno de los factores de mayor influencia en la historia reciente de la paternidad ha sido el ingreso masivo de las mujeres al mercado de trabajo y los consecuentes cambios en las funciones de los miembros de la familia. A partir de la segunda mitad del siglo XX, se produce un incremento de la incorporación de mujeres casadas y con hijos/as pequeños en la fuerza laboral, como causa del mayor nivel educativo de las mujeres y de la coyuntura económica en la región, que las impulsó al ámbito productivo 
para sostener económicamente sus hogares o paliar los ingresos masculinos que se habían perdido o deteriorado.

Paralelamente, se acrecienta la demanda sobre los hombres para que asuman mayores responsabilidades en las tareas del hogar y el cuidado de los hijos/as. En esta tendencia también influyó el desarrollo de evidencia sobre la trascendencia de la paternidad activa o comprometida en el destino de los hijos/as y en los sentimientos de bienestar y felicidad para los propios hombres (Barker \& Verani, 2008).

Pero, ¿hasta qué punto esta pretensión de mayor participación de los hombres en los cuidados de sus hijos/as ha tenido un correlato en los comportamientos al interior de la unidad familiar? ¿En qué medida el rol del padre está siendo redefinido para incluir el paternaje ejercido por padres presentes, afectuosos, contenedores y nutrientes?

En rigor, estas mutaciones no han sido lineales ni parejas al interior de la diversidad de los grupos sociales. Más bien, recorrieron trayectos en diversas direcciones y a distintas velocidades, pero, hasta el momento, han resultado insuficientes. Pese a que los hombres han respondido de manera creciente a las normas sociales cambiantes sobre la paternidad, su internalización no ha resultado ser un proceso sencillo. En la vida cotidiana, las actividades que conlleva el cuidado de los niños/as continúan estando muy fuertemente sesgadas por género, con una carga muy desigual que sigue siendo mucho más pesada del lado de las mujeres (Lupica, 2013).

\section{La Participación de los Hombres en el Cuidado de los Hijos/as ${ }^{1}$}

El trabajo que se realiza en los hogares, pero por el cual no se percibe ninguna remuneración -"trabajo doméstico no remunerado"- se ha denominado "trabajo reproductivo" debido a su aporte a la reproducción de la sociedad, ya que incluye el trabajo de cuidado. El cuidado incluye todo lo que hacemos para sostener la vida, para mantener, continuar y reparar nuestro nuestros cuerpos, nuestro ser y nuestro ambiente, de manera que podamos vivir tan bien como sea posible (Tronto, 2007, citado en Lupica, 2014).

El acto de cuidar, incluidas las labores domésticas que conlleva, se considera un trabajo porque implica tiempo, conocimientos, recursos y desgaste de energía y porque genera valor para quienes se benefician de él 
en forma directa y también para la sociedad (CEPAL, 2010, Ravazi \& Staab, 2010, citados en Lupica, 2014).

El trabajo de cuidado es realizado en distintos ámbitos y por personas diferentes. Puede ser desarrollado en la esfera doméstica, dentro de la propia familia, pero también incluye el trabajo que se ejerce en la esfera no doméstica, donde operan el Estado, las empresas, los organismos sin fines de lucro y las sociedades. Los roles y responsabilidades de los distintos actores intervinientes se superponen e interconectan en la compleja organización social del cuidado. El concepto de organización social del cuidado se refiere a la configuración que surge del cruce entre las instituciones que regulan y proveen servicios de cuidados a las personas y los modos como los hogares de distintos niveles socioeconómicos y sus miembros se benefician de ellos. Entender el cuidado como parte de la organización social supone prestar atención no solo a los aspectos microsociales sino también al rol de la política social en la provisión y regulación de las relaciones, actividades y responsabilidades de cuidado asignadas a las distintas instituciones y sujetos (Faur 2012, citada en Lupica, 2014).

En la historia y aún en la actualidad, la principal carga del trabajo no remunerado ha recaído en las familias, y en su interior, en las mujeres. Al asumir el trabajo no remunerado, ellas liberan a los trabajadores potenciales de la responsabilidad del cuidado. De esta manera, el trabajo no remunerado que ellas desarrollan influye sobre la cantidad de personas disponibles para el trabajo remunerado y sobre la cantidad de horas asignadas al mismo.

En todos los países de América Latina con información disponible, las mujeres en edad de trabajar dedican más del doble de tiempo que los hombres al trabajo doméstico no remunerado y, consecuentemente, pueden dedicar menos tiempo que ellos al trabajo remunerado. Pese a lo cual, su carga total de trabajo, que resulta de sumar el tiempo dedicado al trabajo remunerado y el no remunerado, es mucho mayor que el de los hombres (gráficos 1 y 2).

La sobrecarga de trabajo que sufren muchas mujeres genera altos costos para su desarrollo laboral, su salud y calidad de vida. Pero también repercuten negativamente en los cuidados que reciben los niños/as, en las relaciones de pareja, en la subutilización del potencial y aptitudes de las 
mujeres, lo que produce costos individuales (frustración), familiares (menores ingresos) y sociales (menores aportes a la productividad de las empresas y el país).

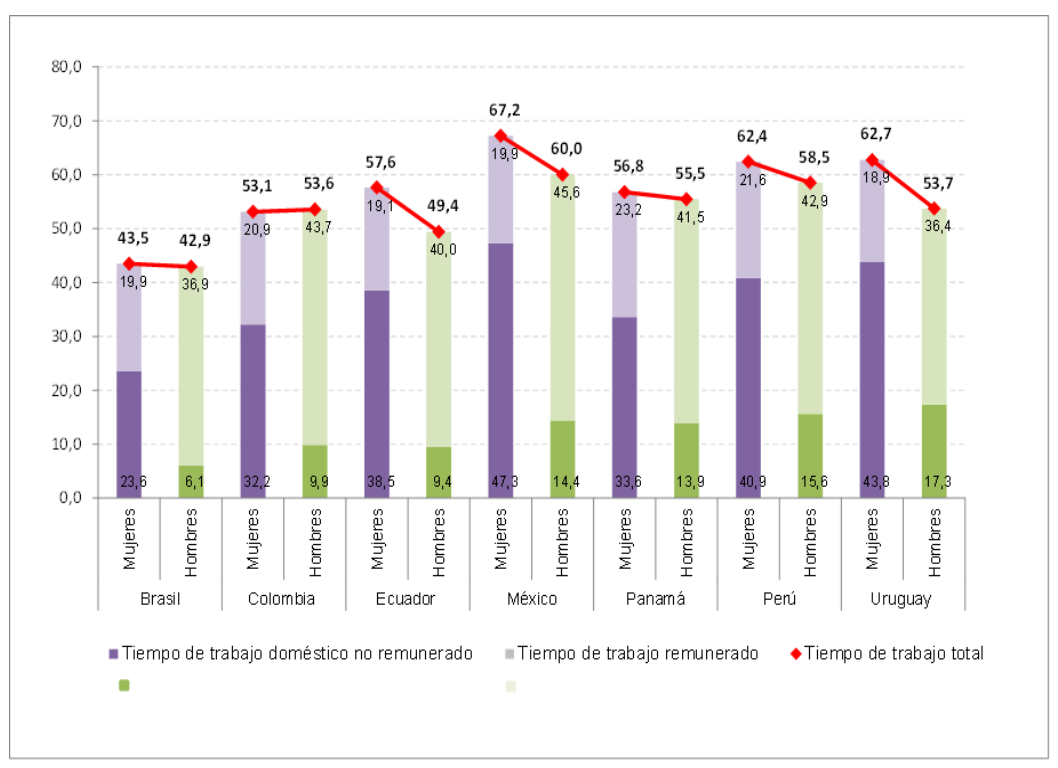

Gráfico 1. América Latina (7 países): tiempo destinado al trabajo total, remunerado y no remunerado. Población de 15 años de edad y más, por sexo, último año disponible (Tiempo en horas semanales).

Fuente: Comisión Económica para América Latina y el Caribe (CEPAL), División de Asuntos de Género, sobre la base de tabulaciones especiales de encuestas de uso de tiempo de los respectivos países. Brasil 2012, Colombia 2012, Ecuador 2012, México 2009, Panamá 2010, Perú 2010 y Uruguay 2007. 


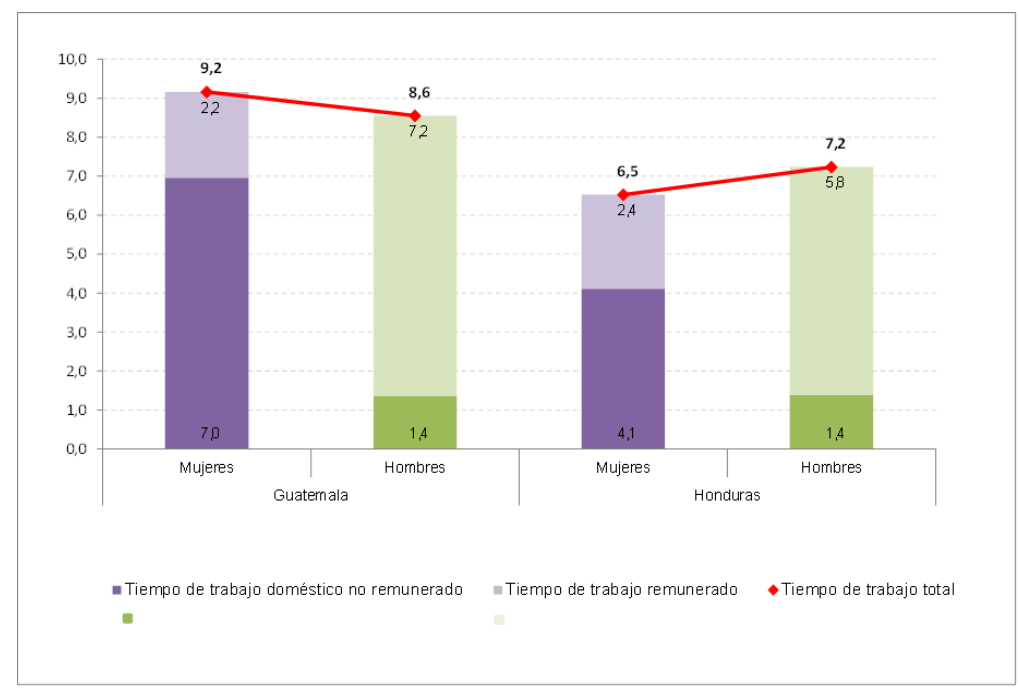

Gráfico $N^{\circ}$ 2: América Latina (2 países): tiempo destinado al trabajo total, remunerado y no remunerado. Población de 15 años de edad y más, por sexo, último año disponible (Tiempo en horas diarias).

Fuente: Comisión Económica para América Latina y el Caribe (CEPAL), División de Asuntos de Género, sobre la base de tabulaciones especiales de encuestas de uso de tiempo de los respectivos países. Guatemala 2011 y Honduras 2009.

La menor participación de los hombres en la crianza de los niños/as puede medirse también por su escasa presencia en las profesiones vinculadas al cuidado, tales como trabajadores del hogar, en centros de desarrollo infantil y escuelas primarias o cuidadores domiciliarios. En efecto, la atención profesionalizada o fuera del hogar de los niños/as es proporcionada mayoritariamente por mujeres. En Argentina, el 86\% de los trabajadores del cuidado son mujeres y una tercera parte de las mujeres trabajadoras lo hace en ocupaciones del cuidado, siendo la mitad de ellas maestras, profesoras, médicas y enfermeras, mientras la otra mitad son trabajadoras de casas particulares (Esquivel, 2010, citada en Lupica, 2014). 
Cuando los hombres participan en el cuidado de los hijos/as, lo hacen como un aporte o ayuda a las mujeres, no como una tarea de la cual se sientan responsables (Barker \& Verani, 2008). En Chile, la encuesta exploratoria "Padres del bicentenario" del año 2010 que realizó el Servicio Nacional de la Mujer entre 800 padres, indica que el $77 \%$ de los encuestados considera que cuando los hijos/as están en el hogar la madre es la principal responsable de su cuidado, el $11 \%$ destaca que son los abuelos y abuelas y, en tercer lugar, el $8 \%$ manifiesta que son ellos mismos. El 43\% de los hombres encuestados declara que no le dedica más tiempo al cuidado de sus hijos/as porque la madre lo hace y no le da espacio o nunca se lo ha pedido, el $11 \%$ declara no saber cómo cuidarlos, mientras que el $7 \%$ confiesa estar de acuerdo con la afirmación "son labores que no me corresponden" (SERNAM, 2012).

En suma, pese a que los hombres han flexibilizado sus roles sociales, el papel de cuidador no ha sido asumido en un plano de igualdad con las mujeres y, por ende, la reestructuración del uso del tiempo no se ha alcanzado exitosamente. El modelo patriarcal -hombre proveedor y mujer dueña de casa- ha demostrado ser muy resistente al cambio y, por consiguiente, los hombres no se han incorporado a las tareas de cuidado en el grado en que la nueva realidad social lo amerita (Hochschild, 2008, citado en Lupica, 2013).

\section{Redistribuir el Trabajo Reproductivo y los Cuidados entre Hombres y Mujeres}

La inequitativa distribución del trabajo reproductivo limita las posibilidades de las mujeres de participar en el mercado de trabajo en condiciones de igualdad con los hombres, contribuir con sus ingresos laborales al bienestar de sus familias y alcanzar su propia autonomía económica. A diferencia de ellos, las mujeres deben considerar las modalidades de concordancia entre el trabajo remunerado y no remunerado. En consecuencia, muchas elijen no participar en el mercado de trabajo o hacerlo en ocupaciones independientes, por cuenta propia o en jornadas parciales como una estrategia de conciliación, empleos que suelen ser de menor calidad, sin protección social y salarios inferiores (Lupica, 2015). 
Pero este no es el único motivo por el cual se deberían redistribuir estas tareas. La presencia del padre, dependiendo de su calidad, es positiva para los hijos/as y para los propios hombres. La paternidad presente y comprometida brinda mayores oportunidades para fortalecer el vínculo filial entre el padre y sus hijos/as, mejora el desarrollo de su estructura psíquica y emocional y les brinda la oportunidad de ser cuidados por ambos progenitores. Además, beneficia a los propios padres, para quienes la relación filial es una de las más importantes fuentes de bienestar y felicidad (Barker \& Verani, 2008).

Adicionalmente, en el ámbito social, la promoción de la parentalidad es un avance simbólico muy importante para la igualdad de género, pues constituye una forma de construir un modelo alternativo de maternidad y paternidad, de asignar un nuevo significado al papel de los padres dentro de los hogares como personas afectivas, interesadas y capaces de asumir responsabilidades familiares. Al mismo tiempo que contribuirá a transformar la concepción de maternidad "intensiva" y asociada al sacrificio y la omnipresencia frente a los hijos/as, juicio social que también dificulta la repartición de las tareas de cuidado y aliviar la sobrecarga que recae sobre las madres (Lupica, 2013).

Redistribuir el trabajo no remunerado entre los hombres y las mujeres de manera más equitativa es un objetivo que está incorporado en la Declaración y Plataforma de Acción de Beijing: “(...) la distribución equitativa entre hombres y mujeres de las responsabilidades respecto de la familia y una asociación armoniosa entre ellos son indispensables para su bienestar y el de su familia, así como para la consolidación de la democracia" (punto 15 de la Declaración de Beijing). También, la Plataforma de Acción establece entre sus objetivos estratégicos "Fomentar la armonización de las responsabilidades de las mujeres y los hombres en lo que respecta al trabajo y la familia" (objetivo estratégico F6). Además, este tema fue recogido por los distintos consensos de la Conferencia Regional sobre la Mujer de América Latina y el Caribe, en particular durante los consensos de Quito (2007) y Brasilia (2010) y el consenso de Montevideo de la Primera Reunión de la Conferencia Regional sobre Población y Desarrollo de América Latina y el Caribe (2013) (CEPAL, 2015).

Si bien estos acuerdos han permitido importantes mejoras en los países de la región, no han logrado superar la persistente brecha de género en la 
asunción del trabajo reproductivo, por lo que sigue siendo imprescindible promover cambios que apunten hacia una sociedad en la que las mujeres y los hombres sean a la vez cuidadores y trabajadores remunerados.

Entre las principales causas de las resistencias a la reestructuración de los tiempos dedicados por las mujeres y los hombres al trabajo para el mercado y en los hogares sobresalen dos principales: por una parte, existe una identificación histórica de los hombres con el trabajo remunerado y de las mujeres con el trabajo reproductivo. Por otra parte, la organización tradicional del trabajo para el mercado también dificulta el mayor compromiso de los hombres con el cuidado. Basta analizar el ordenamiento jurídico laboral de los países de la región para comprobar que fue creado para un trabajador masculino del sector industrial, a jornada completa, responsable del sustento económico familiar, y que no precisa medidas de conciliación porque no se lo considera responsable de las tareas domésticas y de cuidado (Lupica, 2013).

Las disposiciones para facilitar la ejecución del trabajo de cuidado en la región se refieren casi exclusivamente a los derechos de las mujeres asumiendo su doble función de trabajadoras y madres- y casi nunca a los hombres - cuya función como trabajadores parece partir del supuesto de que existe una mujer que cubrirá las necesidades de cuidado de sus hijos/as-. Esta presunción se encuentra implícita en la distribución de licencias para las madres y los padres, y en la regulación sobre los espacios de cuidado infantil en los lugares el trabajo que continúan asociadas exclusivamente a las trabajadoras.

\section{El Apoyo al Cuidado Compartido en la Legislación Laboral}

La legislación laboral sobre protección de la maternidad y apoyo a los trabajadores con responsabilidades familiares es una herramienta fundamental para promover la asunción compartida del cuidado entre las mujeres y los hombres, desde el mundo del trabajo. Dichas normativas tienen el objetivo de prevenir la discriminación y garantizar el derecho a trabajar remuneradamente sin tener que renunciar a proveer el cuidado de los miembros de la familia que así lo requieran y pone al Estado como garante de un nivel básico de protección de los trabajadores/as (Lupica, 2011). 
Los convenios de la Organización Internacional del Trabajo (OIT) y sus respectivas recomendaciones han tenido un notable impacto en el marco conceptual y en las legislaciones internas de los países de América Latina y el Caribe. Los mismos, han ido evolucionando desde la protección de las mujeres en su papel de madres hacia el establecimiento de iguales derechos y oportunidades para los trabajadores de ambos sexos. El reconocimiento de la participación de las madres y de los padres en las responsabilidades familiares, como la protección de las mujeres y de los hombres frente a una discriminación a causa de sus responsabilidades familiares, están incorporados en los Convenios $\mathrm{N}^{\circ} 3$ (1919); $\mathrm{N}^{\circ} 103$ (1952); $\mathrm{N}^{\circ} 183$ (2000) sobre protección de la maternidad y en el Convenio $\mathrm{N}^{\circ} 156$ (1981) sobre los trabajadores con responsabilidades familiares.

En términos de tendencias, se verifica un mayor desarrollo relativo de las normas de protección de la maternidad en el trabajo: entre principios de los noventa y la primera década del dos mil se observa un desplazamiento gradual hacia períodos más largos de licencia por maternidad en todas las regiones del mundo, mejoraron en general los niveles de su remuneración y las fuentes de financiamiento se modificaron de aquellas que dependían sólo del empleador a sistemas mixtos o a cargo de la Seguridad Social (OIT, 2010 citado en Salvador, 2013).

La región de América Latina y el Caribe no constituye una excepción. Como se puede observar en la tabla 1, todos los países prevén licencias de maternidad e incluso varios las extienden a las madres adoptivas. La mayoría de los países cumplen con el C183 que indica que las prestaciones relativas a la maternidad deben ser costeadas por el Estado y no por los empleadores, con el fin de impedir que se discrimine a las mujeres en el mercado de trabajo por el incremento del costo de su contratación para el empleador asociado a su condición real o potencial de madres. En el 61,8\% de los países analizados (21 países sobre un total de 34) las prestaciones pecuniarias durante la licencia de maternidad están a cargo exclusivo de la Seguridad Social, en el 29,4\% (10 países) el régimen de financiamiento es mixto (Seguridad Social y empleadores) y solo en 3 países el financiamiento corre por cuenta de los empleadores exclusivamente (tabla 1).

Todos los países de la región legislan sobre la protección contra el despido de las trabajadoras por razones relacionadas con la maternidad, 


\section{Lupica Carina-Licencias de paternidad y permisos parentales}

fuero que cubre la duración de la licencia de maternidad y, en la mayoría de los casos, también el embarazo y el tiempo de lactancia (ILO, 2014). Además, la mayoría de los países garantizan el derecho de la trabajadora a volver al mismo puesto o a uno equivalente tras su licencia de maternidad, y se prohíbe la exigencia de un examen de embarazo a una mujer que solicita un empleo (excepto para actividades de alto riesgo) (Lupica, 2013).

Sin desconocer estos aspectos positivos, las legislaciones de protección de la maternidad presentan en la región algunas limitaciones que afectan las posibilidades de las mujeres para desarrollarse plenamente en el ámbito laboral y familiar.

En primer lugar, la normativa rige solo en el caso de las asalariadas formales, lo que genera grandes exclusiones e inequidades con relación a otras personas que se desempeñan en el sector informal, en pequeñas empresas, o en el trabajo doméstico remunerado. En varios países se excluyen expresamente determinadas categorías de trabajadoras en el ámbito de la legislación de maternidad, tales como las trabajadoras domésticas; las familiares del empleador o las mujeres que trabajan en empresas familiares; las trabajadoras ocasionales o temporeras y las trabajadoras agrícolas (Lupica, 2013).

En segundo lugar, el marco normativo laboral tiende a centrarse en el momento del embarazo y la recuperación tras el parto, en un tiempo muy acotado, que no permite responder a las demandas conciliatorias cuando los hijos/as crecen. Como se refleja en la tabla 1, en el 76,5\% de los países analizados (26 países de un total de 34) la duración de la licencia de maternidad se encuentra por debajo del límite mínimo de 14 semanas establecido por el C183 de la OIT, y solo tres países (menos del 10\%) establecen la extensión de la licencia a 18 semanas o más, tal cual se estipula en la R191. Sin embargo, es frecuente que las legislaciones nacionales permitan o prescriban cambios en la duración de la licencia de maternidad si durante el embarazo o el parto tiene lugar algún acontecimiento no habitual o inesperado, tal cual aconseja la OIT en el C183 y la R191 (Lupica, 2013).

La duración de la licencia de maternidad es crucial para que la mujer se recupere del parto y pueda regrese en buenas condiciones de salud al trabajo. Cuando dicha licencia es demasiado breve, muchas madres no se sienten preparadas para retomar la vida laboral e incluso abandonan la 
fuerza de trabajo. En contraposición, unos períodos muy prolongados de licencia, también pueden afectar la participación o promoción de las mujeres en el empleo remunerado, con las consiguientes penalizaciones salariales (ILO, 2014).

Además de no cubrir las necesidades de cuidado de los hijos/as de más edad, los marcos legales en la región no incluyen el cuidado de otros miembros de la familia directa, como los adultos mayores, enfermos o las personas con capacidades diferentes. La legislación laboral actual solo prevé una licencia entre uno y tres días, según los países, para los trabajadores/as en caso de muerte de padres o suegros. Así, un desafío para la región consiste en diseñar normas -hoy inexistentes- que posibiliten a los trabajadores y trabajadoras asumir el cuidado de sus progenitores, algo que ocurre cada vez con mayor frecuencia dado el acelerado proceso de envejecimiento de la población (Valenzuela, 2010).

\section{Tabla 1}

Licencias de maternidad y de paternidad en América Latina y el Caribe.

\begin{tabular}{|c|c|c|c|c|c|c|}
\hline \multirow[b]{2}{*}{ País } & \multicolumn{3}{|c|}{ Licencia de Maternidad } & \multicolumn{3}{|c|}{ Licencia de Paternidad } \\
\hline & $\begin{array}{c}\text { Duración } \\
\text { (en } \\
\text { semanas) }\end{array}$ & $\begin{array}{c}\text { Prestación } \\
\text { durante la } \\
\text { licencia }\end{array}$ & $\begin{array}{c}\text { Fuente de la } \\
\text { prestación }\end{array}$ & $\begin{array}{l}\text { Duración } \\
\text { (en días) }\end{array}$ & $\begin{array}{c}\text { Prestación } \\
\text { durante la } \\
\text { licencia }\end{array}$ & $\begin{array}{l}\text { Fuente de } \\
\text { la } \\
\text { prestación }\end{array}$ \\
\hline Antigua y & 13 & $100 \%^{1}$ & mixto $^{9}$ & & No existe & \\
\hline \multicolumn{7}{|l|}{ Barbuda } \\
\hline Argentina & 13 & $100 \%$ & seg soc & 2 & $100 \%$ & empleador \\
\hline Bahamas & 12 & $100 \%$ & $\operatorname{mixto}^{10}$ & 7 & No pago & - \\
\hline Barbados & 12 & $100 \%$ & seg soc & & \multirow{4}{*}{ No existe } & \\
\hline Belice & 14 & $100 \%$ & $\operatorname{seg} \operatorname{soc}^{*}$ & & & \\
\hline Bolivia, Estado & 13 & $95 \%{ }^{2}$ & seg soc & & & \\
\hline \multicolumn{6}{|l|}{ Plurinacional de } & \\
\hline Brasil & 17 & $100 \%$ & seg soc & $5^{19}$ & $100 \%$ & empleador \\
\hline Islas Vírgenes & 13 & $66,7 \%$ & seg soc & & $* *$ & \\
\hline \multicolumn{7}{|l|}{ Británicas } \\
\hline Chile & 18 & $100 \%^{3}$ & seg soc & 5 & $100 \%$ & seg soc \\
\hline Colombia & 14 & $100 \%$ & $\operatorname{seg} \operatorname{soc}^{*}$ & 8 & $100 \%$ & seg soc \\
\hline
\end{tabular}




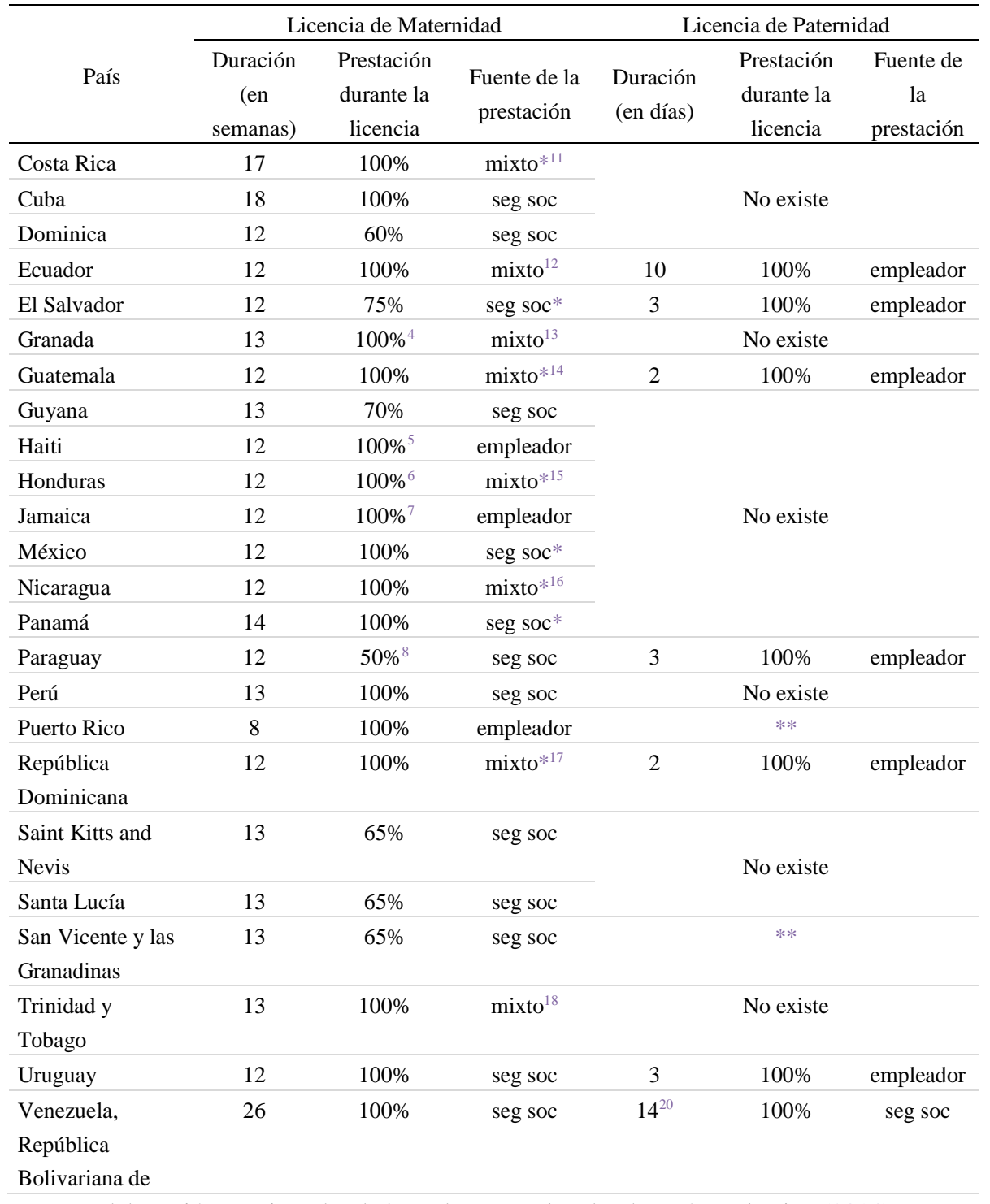

Fuente: Elaboración propia, sobre la base de International Labour Organization (2014).

Notas:

${ }^{1} 100 \%$ seis semanas y $60 \%$ siete semanas. 
${ }^{2} 100 \%$ para el salario mínimo y $70 \%$ para la diferencia entre el salario mínimo y el salario regular.

${ }^{3} 100 \%$ hasta un tope.

${ }^{4} 100 \%$ por dos meses y $65 \%$ para el último mes.

$5100 \%$ por seis semanas.

${ }^{6} 100 \%$ por diez semanas.

${ }^{7} 100 \%$ por ocho semanas.

${ }^{8} 50 \%$ por nueve semanas.

${ }^{9} 60 \%$ seg soc (seguridad social) y $40 \%$ el empleador por las primeras seis semanas.

$102 / 3$ seg soc por trece semanas y $1 / 3$ el empleador por doce semanas.

$1150 \%$ seg soc y $50 \%$ el empleador.

$1275 \%$ seg soc y $25 \%$ el empleador.

${ }^{13} 65 \%$ seg soc por tres meses y $35 \%$ el empleador por dos meses.

$142 / 3$ seg soc y $1 / 3$ el empleador.

$152 / 3$ seg soc y $1 / 3$ el empleador.

${ }^{16} 60 \%$ seg soc y $40 \%$ el empleador.

$1750 \%$ seg soc y $50 \%$ el empleador.

18 2/3 el empleador y $1 / 3$ seg soc.

195 días consecutivos.

${ }^{20} 14$ días consecutivos.

* Si la trabajadora no está cubierta por la seguridad social, pero califica para la licencia por maternidad, su empleador es responsable por el pago total del beneficio de la licencia de maternidad.

** Información no disponible.

Los marcos legales de apoyo al cuidado compartido presentan un menor nivel de desarrollo en comparación con la evolución de las normas de la protección de la maternidad en el trabajo. La legislación se ha desarrollado para las mujeres trabajadoras bajo el supuesto de que ellas son las principales responsables del cuidado familiar y no han integrado a los hombres, hecho que las perjudica frente a los empleadores que presumen que ellas representan un mayor costo laboral relativo. Tres ejemplos claros de esta inequidad:

i) Los hombres no tienen el derecho al "fuero paternal", lo que indica que pueden ser despedidos durante la gestación de su hijo/a incluso después del momento del parto, durante su licencia por paternidad. 
ii) La duración de la licencia por maternidad es de ocho a veintiséis semanas para las trabajadoras mientras que la licencia por paternidad es de apenas dos a catorce días. Además, la licencia por paternidad, cuando es remunerada, es principalmente financiada por el empleador y no por la Seguridad Social, lo que puede dificultar el ejercicio de ese derecho por parte de los hombres.

iii) En las reglamentaciones laborales de toda la región la oferta de servicios de cuidados en el lugar de trabajo está diseñado y restringido a las mujeres, debe ser provista por el empleador $\mathrm{y}$, en general, la obligatoriedad es proporcional al número de trabajadoras del establecimiento. De esta manera, se ignora la responsabilidad de cuidado del padre trabajador y se estimula a los empleadores a contratar menos mujeres que lo indicado por la norma. Por otra parte, la fiscalización del Estado muchas veces es insuficiente y es común el incumplimiento no sancionado de dicha obligación. Tampoco suele transferirse el equivalente monetario para que madres y padres trabajadores contraten servicios privados, donde la oferta es mayor, aunque estratificada de acuerdo a los ingresos de cada familia (Pautassi \& Rico, 2011).

Finalmente, las medidas laborales que incluyen el concepto de trabajador de ambos sexos con responsabilidades familiares son prácticamente inexistentes. Solo dos países en la región garantizan una licencia parental durante el período inmediatamente posterior a la licencia de maternidad: Cuba y Chile. En Cuba, los padres pueden decidir que uno de ellos quedará en casa cuidando a su hijo/a hasta que cumple un año de edad, a cambio de una retribución equivalente al $60 \%$ del beneficio de la licencia maternal. En Chile, a partir de la modificación del Sistema de Protección de la Maternidad en el año 2011, si ambos padres trabajan de manera remunerada, la madre puede decidir traspasar hasta seis meses de su permiso postnatal parental al padre, quien recibe un subsidio equivalente a su salario con un tope mensual. Este constituye el avance regional reciente más importante respecto a la normativa laboral a favor de la parentalidad (Lupica, 2015). 


\section{Licencias Parentales: Implementación y Resultados Recientes en Chile ${ }^{2}$}

El permiso parental o las licencias parentales consisten en un período de tiempo durante el cual un trabajador/a puede ausentarse de su puesto de trabajo con su reserva por el nacimiento, la adopción o tutela de un hijo/a para su cuidado, lo que garantiza la disponibilidad de tiempo y dinero para cuidar (Lupica, 2013).

Estas licencias forman parte de un destacado cambio jurídico caracterizado por la titularidad indiferenciada o neutra de los derechos de conciliación: se los reconoce como facultades individuales de los trabajadores, con independencia de su sexo. Ello conlleva la asunción de un modelo de familia con una doble fuente de ingresos provenientes del trabajo remunerado del hombre y de la mujer, más en consonancia con la realidad familiar actual (Caamaño, 2008).

Aunque las licencias parentales no figuran como tal en ninguno de los convenios de la OIT, el reconocimiento de la participación de los padres en las responsabilidades familiares en general y la licencia parental en particular están incorporadas implícitamente en la Recomendación $\mathrm{N}^{\circ} 191$ que acompaña al Convenio $\mathrm{N}^{\circ} 183$ y en la Recomendación $\mathrm{N}^{\circ} 165$ que acompaña al Convenio $\mathrm{N}^{\circ} 156$. En ambas recomendaciones se sostiene que tras la licencia de maternidad la madre o el padre deberían poder disfrutar de un permiso de licencia parental sin perder el empleo y conservando los derechos que se derivan de él (Lupica, 2013).

El Permiso Postnatal Parental (PPP) en Chile y su respectivo subsidio fueron establecidos por la Ley $\mathrm{N}^{\circ} 20.545$ en el año 2011 y forman parte del Sistema de Protección a la Maternidad contenido en el Código del Trabajo, en favor de todas las mujeres trabajadoras afiliadas al sistema previsional. Mediante la sanción de la ley, las trabajadoras tienen derecho a ausentarse del trabajo por un período total de doce semanas a continuación del período postnatal para cuidar del hijo/a recién nacido. Durante el tiempo en que se hace uso del permiso, la trabajadora recibe un subsidio por incapacidad laboral, que es un beneficio previsional (de la Seguridad Social) que consiste en una prestación de dinero que se paga en reemplazo de la remuneración de la trabajadora dependiente del sector público o privado, o en reemplazo de la renta de la trabajadora o trabajador independiente, siempre que cumplan los requisitos que exige la ley. 


\section{Lupica Carina-Licencias de paternidad y permisos parentales}

Las mujeres pueden elegir si tomar el postnatal a tiempo completo por una duración total de doce semanas o tomarlo a media jornada, en cuyo caso el tiempo se extiende a dieciocho semanas. Las mujeres que toman el postnatal a tiempo completo reciben un subsidio equivalente al $100 \%$ de su remuneración con un tope (a excepción de las funcionarias del sector público), mientras que la que lo toman a media jornada tienen derecho a un subsidio equivalente al $50 \%$ de su remuneración ${ }^{3}$.

Cuando ambos padres trabajan de manera remunerada, y a partir de la séptima semana del permiso, la madre puede traspasar parte de las semanas restantes al padre. Las semanas deben ubicarse al final del período de PPP y solo se pueden ceder semanas completas (siete días corridos), en la misma modalidad (a tiempo completo o media jornada) elegida por la madre. En consecuencia, si la madre decidió tomar doce semanas del PPP a jornada completa, puede traspasar al padre hasta un máximo de seis semanas a jornada completa, mientras que si ella decidió tomar dieciocho semanas a media jornada, puede traspasar al padre hasta un máximo de doce semanas, en media jornada. El PPP es independiente de la licencia por paternidad paga de cinco días para el padre al momento de nacer su hijo/a que sigue vigente.

Cuando el padre hace uso del PPP, el subsidio se calcula sobre la base de sus propias remuneraciones y también tiene un tope mensual, con excepción de los funcionarios públicos. El padre tendrá derecho a fuero laboral por el doble del período que se tome a jornada completa o a un máximo de tres meses si lo utiliza a jornada parcial, contados desde diez días antes de iniciarse el permiso.

De acuerdo a estudios previos a la implementación del PPP, los padres en Chile manifestaban tener deseos y voluntad de participar más en las tareas reproductivas. La encuesta Padres del Bicentenario del SERNAM, arroja que el $73 \%$ de los padres entrevistados consideraba necesario contar con más días de permiso cuando nace un hijo (SERNAM, 2011). Según los datos del Barómetro Mujer y Trabajo del año 2011, el 71,7\% de los hombres entrevistados, trabajadores dependientes de centros urbanos de la Región Metropolitana, manifestaron estar dispuestos a aceptar algunas semanas del PPP si la madre de su hijo/a estuviese dispuesta a transferírselo, el $18,7 \%$ declaró que no lo haría y el $9,6 \%$ no supo o no respondió (ComunidadMujer, Datavoz \& OIT, 2011). 
Pese a esto, una vez que el PPP comenzó a regir, fueron muy pocos los padres que hicieron uso del mismo. Desde noviembre de 2011 y hasta agosto de 2014 solo 713 madres traspasaron semanas del PPP al padre (el $0,3 \%$ del total de los subsidios iniciados), lo que representa un promedio de apenas 21 permisos mensuales.

Entre las razones que contribuyen a explicar el escaso uso del PPP por los padres, se pueden distinguir dos grandes grupos: las barreras culturales y sociales al cuidado compartido y algunos aspectos del diseño del permiso.

En relación a la primera dificultad, las expectativas culturales sobre la participación masculina en el cuidado de los hijos/as cumplen un rol muy importante. De acuerdo a los datos del Barómetro Mujer y Trabajo (2011), el 54,4\% de las mujeres entrevistadas antes de implementarse el PPP manifestaban disponibilidad a compartir parte del PPP con el padre de su hijo/a, el 40,3\% sostuvo que no lo haría y 5,3\% manifestó no saber o no respondió. Esto significa, que solo una de cada dos madres mostraba voluntad de compartir el cuidado de su hijo/a recién nacido con el padre.

En relación con las actitudes de los hombres, el resultado del estudio cuantitativo IMAGES (2011) revela que el 76,6\% de los hombres entrevistados antes de la implementación del PPP no se tomaron la licencia de paternidad (5 días), solo un 20,6\% señaló haber tomado una licencia pagada (derecho garantizado por normativa laboral a los trabajadores con contrato) y un 2,6\% declaró haber tomado una licencia no pagada. En cuanto a las principales razones que entregaron los hombres para no haber tomado el permiso postnatal, se observa que cerca de la mitad señaló que el trabajo no se lo permitió $(51,9 \%)$, mientras que un $13,9 \%$ manifestó que no tenía condiciones económicas para hacerlo y un 10,2\% señaló que simplemente no quiso tomarse el permiso (Aguayo, Correa \& Cristi, 2011).

A la luz de estos resultados, se constata la disonancia vigente entre los nuevos discursos y las viejas prácticas respecto a la división sexual del trabajo reproductivo, a la vez que era factible predecir que el uso del PPP por parte de los hombres no sería masivo.

A las visiones culturales tradicionales sobre quién debe encargarse de la atención y crianza los hijos/as pequeños, se suma la realidad del contexto socio laboral actual en Chile, caracterizado por extensas jornadas laborales, el miedo a perder el trabajo y el elevado nivel de endeudamiento de las 


\section{Lupica Carina-Licencias de paternidad y permisos parentales}

familias, lo que también representa un obstáculo importante para la mayor participación masculina en los cuidados.

En relación al diseño del PPP, éste fue concebido como una nueva licencia para las madres, quienes pueden cederla en parte y de manera voluntaria a los padres para el cuidado de sus hijos/as. Esto se contradice con la experiencia internacional, que indica que una de las características que contribuye a que la tasa de uso de los permisos parentales sea más igualitaria entre hombres y mujeres es el criterio de intransferibilidad o cuota parte de los permisos para hombres y mujeres, ya que los padres por lo general toman el tiempo de uso exclusivo dentro de la licencia parental (Lupica, 2013).

Adicionalmente, se produce una superposición del PPP con el tiempo recomendado de lactancia materna exclusiva durante los primeros seis meses de vida por la Organización Mundial de la Salud y el Fondo de las Naciones Unidas para la Infancia (UNICEF). De esta manera, los mensajes a las madres pueden resultar contradictorios: se recomienda la lactancia materna exclusiva durante los seis primeros meses de vida del niño/a y, por otra parte, se pretende que ella ceda parte de esos días al padre de su hijo/a.

Por otra parte, la tasa de uso de los permisos parentales está vinculada a la presencia o ausencia de otros instrumentos, recursos y servicios de cuidado y conciliación. Por tanto, es importante analizar las posibilidades y el funcionamiento integral de las licencias de maternidad, paternidad, parentalidad, por cuidado del hijo/a menor de un año grave y los servicios de cuidado como parte de un sistema de políticas de armonización favorables a las familias. En ese sentido también resulta paradójico promover el cuidado compartido desde el PPP pero excluir a los trabajadores masculinos en Chile de otros beneficios para el cuidado en el trabajo como la garantía de salas cuna, con excepción de los funcionarios públicos.

De esta forma, es loable concluir que con la creación del permiso postnatal parental en Chile se logró establecer un instrumento legal que posibilita el mayor involucramiento de los hombres en el cuidado de sus hijos/as, lo que constituye un progreso fundamental para el cambio cultural necesario a favor del cuidado compartido. A partir de ello, es recomendable fortalecer las acciones de difusión de la nueva ley y la promoción de la adopción del postnatal parental por parte de los padres. 


\section{MCS - Masculinities and Social Change, 5(3) 315}

\section{Reflexiones Finales}

Tal como se analizó a lo largo del artículo, con excepción de la reciente creación del permiso postnatal en Chile, el principal avance en las legislaciones laborales de los países de la región para promover los cuidados compartidos entre hombres y mujeres ha sido el establecimiento de la licencia de paternidad. La discriminación o restricción de los beneficios para los trabajadores masculinos reafirma a las mujeres en el rol de responsables casi únicas del cuidado del hogar y los niños/as, lo que conlleva un costo importante para las mujeres, los hombres y los niños/as.

Se vuelve necesario entonces introducir algunas modificaciones en los marcos normativos de la región para reflejar con mayor precisión y acompañar de manera más efectiva los cambios sociales y familiares acontecidos.

Entre las principales medidas, en cada uno de los países, se podrían analizar los costos y la factibilidad de extender la duración de las licencias por paternidad, incluir las licencias parentales remuneradas, legislar sobre licencias familiares para cuidar a otras personas dependientes que no sean los hijos/as pequeños y que puedan ser tomadas por las trabajadoras y los trabajadores e incorporar la posibilidad de excedencias para los hombres.

También, es importante modificar las normativas laborales para establecer la obligación de las empresas, indistintamente del sexo de sus empleados, de instalar, mantener o proporcionar centros de cuidado infantil en los lugares de trabajo. Los Estados deben fortalecer sus sistemas de fiscalización y sanciones por incumplimiento y estudiar las posibilidades de apoyar a las familias para la adquisición de servicios de cuidado en el sector privado, mediante subsidios o exenciones fiscales. Adicionalmente, desde las políticas públicas se debe promover la ampliación y regulación de los servicios de cuidado con el fin de aumentar su oferta, garantizar su calidad $\mathrm{y}$, al mismo tiempo, promover condiciones de trabajo decente para las y los trabajadores del cuidado.

Asimismo, el Estado debe profundizar la política de sensibilización y transformación cultural para incentivar la adopción de las licencias de paternidad y parentales por parte de los hombres, a través de distintas instancias, como campañas de información sobre la importancia y beneficios del ejercicio compartido de las funciones parentales para las 
familias, las empresas y la sociedad. El sistema educativo y los medios de comunicación son actores claves con los cuales se debería profundizar esta labor.

Finalmente, es necesario evaluar el uso efectivo de las licencias de paternidad por parte de los hombres e identificar los factores que facilitan o inhiben su práctica, con el fin de derivar lecciones y crear las condiciones para que se haga uso de ellas.

Las licencias de paternidad y los permisos parentales son herramientas útiles para modificar la inequitativa división sexual del trabajo. No obstante, las normativas por sí solas no bastan para alterar las pautas socioculturales predominantes. En ese sentido, se requiere de acciones positivas y de políticas públicas que posibiliten un cambio cultural para fomentar una nueva percepción del padre trabajador ante los compromisos familiares, tal como quedó demostrado con la experiencia reciente del permiso postnatal en Chile. Saldar esta deuda aún pendiente puede tener efectos positivos sobre la igualdad de género en el hogar y en el trabajo, y ser indicio de cambios en las relaciones y los roles de las madres y los padres, así como en los estereotipos de género predominantes en la región.

\section{Notas}

${ }^{1}$ Esta sección se elaboró sobre la base de Lupica (2014).

${ }^{2}$ Esta sección se elaboró sobre la base de Lupica (2015).

${ }^{3}$ A principios de 2016, en Chile se aprobó un proyecto de ley que perfecciona el permiso postnatal parental, ya que elimina el tope del subsidio y asegura el pago íntegro de la remuneración al funcionario o funcionaria del sector público durante la licencia. Asimismo, se contempla la habilitación del derecho de sala cuna en la entidad empleadora del padre cuando ambos sean funcionarios públicos. El proyecto estaba en etapa de promulgación al momento de finalizar la redacción de este artículo.

\section{Referencias}

Aguayo, F., Correa, P., \& Cristi, P. (2011). Encuesta IMAGES Chile. Resultados de la Encuesta Internacional de Masculinidades y Equidad de Género. Santiago de Chile: Cultura Salud/EME. Recuperado de: 
http://portales.mineduc.cl/usuarios/convivencia_escolar/doc/2012120 41625540.2011EncuestaIMAGESChileCulturaSaludEME.pdf Barker, G., \& Verani, F. (2008). La participación del hombre como padre en la región de Latinoamérica y el Caribe: una revisión de literatura crítica con consideraciones para políticas. Rio de Janeiro:

Promundo-Save the Children. Recuperado de: http://promundoglobal.org/wp-content/uploads/2015/01/Laparticipacion-del-hombre-como-padre-en-la-region-deLatinoamerica-y-el-Caribe.pdf

Biblioteca del Congreso Nacional de Chile-BCNC (2011). Historia de la Ley $N^{o}$ 20.545. Modifica las normas sobre protección a la maternidad e incorpora el permiso del Postnatal Parental. (D. Oficial de 17 de octubre, 2011). Recuperado de http://www.bcn.cl/catalogo/detalle_libro?bib=243276\&materia=Mate rnidad\%20--\%20Chile

Caamaño, E. (2008). El permiso parental y la progresiva inclusión del padre en los derechos para la armonización del trabajo y la vida familiar. Revista de Derecho de la Pontificia Universidad Católica de Valparaiso XXXI, 31, 325 - 354. doi:10.4067/S071868512008000200008

Comisión Económica para América Latina y el Caribe-CEPAL (2015). Informe regional sobre el examen y la evaluación de la Declaración y la Plataforma de Acción de Beijing y el documento final del vigesimotercer período extraordinario de sesiones de la Asamblea General (2000) en los países de América Latina y el Caribe. S. Montaño (Ed.). Recuperado de http://repositorio.cepal.org/bitstream/handle/11362/37718/S1421043 _es.pdf? sequence $=4$

ComunidadMujer, DataVoz, \& OIT (2011). III Barómetro Mujer y Trabajo. Recuperado de http://es.slideshare.net/comunidadmujer/iii-barmetromujer-y-trabajo-2011

Fondo de Población de las Naciones Unidas-UNFPA, \& Comisión Económica para América Latina y el Caribe-CEPAL (2005). Masculinidad y factores socioculturales asociados al comportamiento de los hombres: estudio en cuatro países de Centroamérica. M. Ortega, R. Centeno, \& M. Castillo (Eds.). 
318 Lupica Carina-Licencias de paternidad y permisos parentales

Recuperado de

http://www.berdingune.euskadi.eus/contenidos/informacion/material/ es_gizonduz/adjuntos/Masculinidad\%20y\%20factores\%20sociocultu rales \%20asociados\%20al\%20comportamiento\%20de $\% 20$ los $\% 20$ ho mbres\%20estudio\%20en\%20cua.PDF

International Labour Organization-ILO (2014). Maternity and paternity at work: law and practice across the world. Geneva. Recuperado de http://www.ilo.org/wcmsp5/groups/public/---dgreports/--dcomm/--publ/documents/publication/wcms_242615.pdf

Lupica C. (2015). Corresponsabilidad de los cuidados y autonomía económica de las mujeres: lecciones aprendidas del Permiso Postnatal Parental en Chile. Santiago de Chile: Naciones Unidas. Recuperado de:

http://repositorio.cepal.org/bitstream/handle/11362/37878/S1500262 _es.pdf?sequence $=4$

Lupica, C. (2014). Recibir y brindar cuidados en condiciones de equidad: desafios de la protección social en Argentina. Documento de trabajo $N^{\circ}$ 5. Buenos Aires: Organización Internacional del Trabajo-OIT. Recuperado de: http://www.ilo.org/wcmsp5/groups/public/--americas/---ro-lima/---ilobuenos_aires/documents/publication/wcms_302535.pdf

Lupica, C. (2013). Trabajo decente y cuidado compartido: hacia una propuesta de parentalidad. Santiago de Chile: Organización Internacional del Trabajo-OIT y Programa de las Naciones Unidas para el Desarrollo-PNUD. Recuperado de:

http://www.oitcinterfor.org/sites/default/files/file_publicacion/113B0 9_86_span.pdf

Lupica, C. (2011). Los padres que trabajan en la Argentina ¿tienen garantizado su derecho a cuidar? Paternidad y parentalidad en la legislación laboral. Boletín de la maternidad, 12, 15-19. Recuperado de http://www.o-

maternidad.org.ar/LinkClick.aspx?fileticket=WhFxczG0CrM\%3d\&ta bid $=132 \& \operatorname{mid}=753$

National Council on Family Relations (2003). Marriage Promotion in LowIncome Families. Retrieved from https://www.aafcs.org/res/NCFR_Marriage.pdf 
Oiberman, A. (1998). Padre-bebé. Inicio de una relación. La Plata:

Editorial de la Universidad de La Plata.

Olavarría, J. (2003). Los estudios sobre masculinidades en América Latina.

Un punto de vista. Anuario Social y Política de América Latina y el

Caribe, 6, 91-98. Recuperado de http://www.pasa.cl/wp-

content/uploads/2011/08/Los_Estudios_sobre_Masculinidades_en_A

merica_Latina_Olavarria_Jose.pdf

Pautassi, L., \& Rico, M. N. (2011). Licencias para el cuidado infantil.

Derecho de hijos, padres y madres. Desafíos. Boletín de la infancia y

adolescencia sobre el avance de los Objetivos de Desarrollo del

Milenio, 12, 4-9. Recuperado de

http://www.unicef.org/lac/desafios12_cepal-unicef.pdf

Programa de Naciones Unidas para el Desarrollo-PNUD (2010). Desarrollo

Humano en Chile 2010. Género: los desafíos de la igualdad.

Santiago de Chila: Programa de las Naciones Unidas para el

Desarrollo (PNUD). Recuperado de:

http://desarrollohumano.cl/idh/download/PNUD_LIBRO.pdf

Salvador, S. (2013). Análisis de costos y posibles impactos de diferentes

modelos de licencias por maternidad, paternidad y parentales.

Informe final de consultoría en el marco del proyecto URY2U503.

[online] Fondo de Población de las Naciones Unidas-UNFPA.

Recuperado de

http://www.unfpa.org.uy/userfiles/publications/76_file1.pdf

Servicio Nacional de la Mujer-SERNAM (2012). Estudio de los padres.

Participación en la crianza de los hijos. Recuperado de

http://estudios.sernam.cl/documentos/?eMjI2NDg1Ng==-

Estudio_de_los_Padres:_Participaci\%C3\%B3n_en_la_crianza_de_lo s_hijos_

Servicio Nacional de la Mujer-SERNAM (2011). Encuesta Nacional

Bicentenario 2011. Especial Familia, Maternidad y Crianza.

Recuperado de

http://estudios.sernam.cl/documentos/?eMjA2NzkxMg==-

Encuesta_Nacional_Bicentenario_2011_\%E2\%80\%93_Especial_Fa milia,_Maternidad_y_Crianza 
Ugalde, Y. (2008). Propuesta de indicadores de paternidad responsable. Naciones Unidas, Comisión Económica para América Latina y el Caribe-CEPAL.

Valdés, X. (2009). El lugar que habita el padre en Chile contemporáneo. Estudios de las representaciones sobre paternidad en distintos grupos sociales. Polis, Revista de la Universidad Bolivariana, 8(23), 385410. Santiago de Chile. Recuperado de http://www.scielo.cl/pdf/polis/v8n23/art17.pdf

Valenzuela, M. E. (2010). Trabajo y responsabilidades familiares en el contexto del envejecimiento: ¿Quién se encarga del cuidado? En A. Prado \& A. Sojo (Eds.), Envejecimiento en América Latina. Sistemas de pensiones y protección social integral (pp. 255-282). Santiago de Chile: Libros de la CEPAL 110.

Carina Lupica es miembro del Consejo de Asesores del Observatorio de Maternidad, Argentina.

Contact Address: Direct correspondence to Carina Lupica, Observatorio de Maternidad, Buenos Aires, email: lupica.carina@gmail.com 
Instructions for authors, subscriptions and further details:

http://mcs.hipatiapress.com

\section{Men, Masculinities and Teaching in Early Childhood Education}

Javier Díez-Palomar ${ }^{1}$

1) University of Barcelona

Date of publication: October $21^{\text {th }}, 2016$

Edition period: October 2016-February 2017

To cite this article: Diez-Palomar, J. (2016). Men, Masculinities and

Teaching in Early Childhood Education [Review of the book]. Masculinities and Social Change, 5(3), 321-322. doi: 10.17583/MCS.2016.2351

To link this article: http://dx.doi.org/10.4471/MCS.2016.2351

PLEASE SCROLL DOWN FOR ARTICLE

The terms and conditions of use are related to the Open Journal System and to Creative Commons Attribution License (CC-BY). 
MCS - Masculinities and Social Change Vol. 5 No. 3 October 2016

pp. 321-322

\section{Reviews (I)}

Simon Brownhill, Jo Warin and Inga Wernersoon (eds.) (2016), Men, Masculinities and Teaching in Early Childhood Education. London: Routledge. ISBN: 978-1-138-79771-0

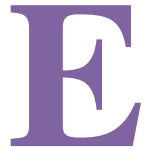

ste libro editado por Simon Brownhill, Jo Warin and Inga Wernersoon discute el papel que juegan los hombres en la educación infantil, no solo desde un punto de vista professional, como cuidadores, sino que también desde el ámbito de los valores, las actitudes, las creencias o el imaginario social que envuelve la educación infantil.

El mundo de la educación siempre ha estado influenciado por los temas de género. En la enseñanza de las matemáticas, por ejemplo, durante varias décadas se ha tratado de "recuperar" a los "chicos rebeldes"; este perfil de estudiante que para ser "popular" en el grupo de iguales tenía que alardear de sacar malos resultados académicos. Los roles de género se han utilizado muchas veces como referentes para la definición de la identidad en ese tipo de situaciones, asociando el rol violento a un determinado tipo de chicos.

Este libro es una alternativa que discute en profundidad, y desde la educación infantil, este rol de género; y en concreto, de "ser hombre." Los autores comienzan haciendo una reflexión, y es que "no quieren escribir un libro para recuperar a los chicos rebeldes", sino que lo que plantean a lo largo de estas páginas, junto con todas las personas que escriben los diferentes capítulos, es plantear que existen otros tipos de masculinidad, más allá de la masculinidad hegemónica.

Junto a esta reflexión de fondo, el libro presenta tres partes bien diferenciadas. En la primera de ellas el tema central es la discusión de la masculinidad desde las esferas política y legislativa. A través de varios capítulos, los autores invitados en este volumen ponen ejemplos de diversos

2016 Hipatia Press

ISSN: 2014-3605

DOI: 10.17583/MCS.2016.2351 
países, sobre cómo se regula el papel y el rol del "hombre" en la educación infantil. Aspectos como la interpretación reproductora de los roles de género que los niños y las niñas ya en la escuela infantil aprenden cuando ven a su alrededor cómo actúan sus "mayores", el cómo el profesorado (los cuidadores y las cuidadoras) construyen una imagen de la profesión de careworker que es eminentemente feminizada, a pesar de que también hay hombres que cuidan a niños/as de manera profesional, etc., son temas todos ellos con un alto contenido crítico, y los autores/as nos invitan con sus reflexiones a pensar de manera crítica cómo definimos la identidad de género en nuestras escuelas.

En la segunda parte el tema estrella son los estudios de caso sobre género, aprendizaje y care. En lugares tan diferentes como Indonesia o Noruega, las autoras de los capítulos de esta parte del libro relatan emocionantes ejemplos que ilustran el debate sobre ideologías, creencias, actitudes, y cómo todo ello crea una determinada identidad de género que se traspasa a nuestros hijos y nuestras hijas en las escuelas maternales y de infantil.

En la tercera parte, las autoras invitadas regresan al enfoque profesionalizador del trabajador/a cuidador/a de niños/as. En Suecia, por ejemplo, se relata cómo los chicos que trabajan en las escuelas de infantil son "pioneros", puesto que se adentran en un terreno profesional tradicionalmente reservado a las mujeres. En Japón, a su vez, vemos que el ser "maestro de educación infantil" está rodeado de toda una serie de normas que definen y ponen los límites del quehacer profesional del hombre, desde el punto de vista de su rol e identidad de género.

En definitiva, se trata de un libro innovador, que abre nuevas fronteras y, en buena mesura, inspirador, para repensar de manera crítica el papel del hombre como maestro de escuela maternal y de infantil. ¿Tienen los hombres que feminizarse o podemos ser capaces de construir una identidad masculina alternativa, que no se deje avasallar, pero a la vez, profundamente respetuosa con los valores humanos, de género, comprometida con el rechazo total a la violencia, y profundamente masculina? Dejo ahí la pregunta para animar a los futuros lectores y lectoras en sus discusiones.

Javier Díez-Palomar, University of Barcelona jdiezpalomar@ub.edu 


\section{Hipatia Press}

Instructions for authors, subscriptions and further details:

http://mcs.hipatiapress.com

\section{Masculinity and the New Imperialism: Rewriting Manhood in British Popular Literature, 1870-1914.}

Teresa Morlà Folch ${ }^{1}$

1) Universidad Rovira i Virgili, Spain

Date of publication: October $21^{\text {th }}, 2016$

Edition period: October 2016-February 2017

To cite this article: Morlà, T. (2016). Masculinity and the New Imperialism: Rewriting Manhood in British Popular Literature, 1870-1914. [Review of the book]. Masculinities and Social Change, 5(2), 323-324-. doi: 10.17583/MCS.2016.2348

To link this article: http://dx.doi.org/10.4471/MCS.2016.2348

\section{PLEASE SCROLL DOWN FOR ARTICLE}

The terms and conditions of use are related to the Open Journal System and to Creative Commons Attribution License (CC-BY). 


\section{Reviews (II)}

Deane, B. (2014). Masculinity and the New Imperialism: Rewriting Manhood in British Popular Literature, 1870-1914. Cambridge: Cambridge University Press. ISBN: 978-1-107-06607-6

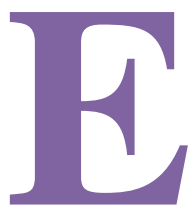

ste libro revisa los ideales de la masculinidad en Inglaterra entre el periodo de 1870 - 1924, conocido como el Nuevo Imperialismo. El país se enfrentaba a nuevos desafíos, ampliando su influencia económica, política y militar, a la vez que utilizaba doctrinas de superioridad racial en sus colonias, protectorados o anexiones. Ante esta especificidad, Deane muestra como el discurso empleado por el Nuevo Imperialismo viene marcado por la modificación de los principios de masculinidad, uno de los cambios más característicos de la época: la búsqueda del honor.

El libro se caracteriza por las numerosas referencias y dominio de la literatura popular, poemas e historias. De manera excepcional el autor entrelaza fronteras reales e imaginarias, elaborando una narrativa académica, clara y elocuente. Las referencias bibliográficas le permiten discernir patrones generales de supuestos culturales en torno a la masculinidad muy clarificadores para los y las lectoras.

En la introducción se desarrolla una exhaustiva contextualización histórica, en esta línea, puntualiza que el Imperio era la fuente y prueba de la gloria de Inglaterra. En los dos primeros capítulos se presentan temas generales en relación al vinculo entre masculinidad y el Nuevo Imperialismo. A su vez, se vincula al periodo histórico con la complicada relación de los estereotipos masculinos en las colonias británicas. Concretamente, en el segundo capítulo, expone la asunción de ropa extranjera como medio de apropiación de signos de masculinidad exótica. 


\section{Morlà - Masculinity and the New Imperialism [Book Review]}

Este aspecto, lo relaciona como un tipo de performidad de la masculinidad en busca de prestigio, reimaginando los gestos de la autoridad imperial sobre los nativos, es decir, para la obtención de nuevas formas el poder de lo masculino.

Seguidamente, en los capítulos 3 y 4 enfatiza como, en el periodo estudiado, se utilizaron representaciones de la infancia. En esta línea, presenta lo que detalla como una de las características preferidas de la nueva imaginación imperialista: el niño que nunca crece (por ejemplo uno de los más conocidos en la literatura: Peter Pan), y es que entre los héroes más venerados del Imperio nos encontramos con muchos hombres ostentosamente infantiles. Deane relaciona esta característica al fin de poder ver el Imperialismo como un juego de aventuras.

En los últimos tres capítulos, se centra de manera más general en el cambio histórico, describe la proliferación de historias de mundos exóticos perdidos. Para ello, se centra básicamente en las contribuciones de Kipling, Haggard y Doyle al fin de mostrar cómo los británicos comenzaron a entender la barbarie como un aspecto de masculinidad. En el último capítulo se centra en H.G. Wells con el objetivo de demostrar que incluso un escritor con grandes dotes imaginativas y principios progresistas, también fue condicionado por los debates políticos, culturales, e imperiales de la época, de modo que sus visiones del futuro eran a la vez fundamentalmente inmutable y profundamente enraizada en el pasado. Por un lado, los textos de Wells, según Deane, desprenden una atracción hacia el pacifismo racional y por el otro, una fascinación salvaje hacia la violencia.

Sin duda, este libro es fundamental para todas aquellas personas que tienen interés por este periodo histórico. Asimismo, es de interés para todas aquellas personas que tienen fascinación por las nociones cambiantes de la masculinidad. Puesto que, a lo largo del libro, y como el propio autor evidencia, se nos brinda la oportunidad de abandonar la dicotomía de ser mejores hombres o mejores mujeres, reflexionando sobre como ser en definitiva, mejores personas y más libres.

Teresa Morlà Folch, Universidad Rovira i Virgili teresa.morla@urv.cat 